\title{
Site M0061
}

T. Andrén, B.B. Jørgensen, C. Cotterill, S. Green, E. Andrén, J. Ash, T. Bauersachs, B. Cragg, A.-S. Fanget, A. Fehr, W. Granoszewski, J. Groeneveld, D. Hardisty, E. Herrero-Bervera,

O. Hyttinen, J.B. Jensen, S. Johnson, M. Kenzler, A. Kotilainen, U. Kotthoff, I.P.G. Marshall, E. Martin, S. Obrochta, S. Passchier, N. Quintana Krupinski, N. Riedinger, C. Slomp, I. Snowball, A. Stepanova, S. Strano, A. Torti, J. Warnock, N. Xiao, and R. Zhang ${ }^{2}$

\section{Chapter contents}

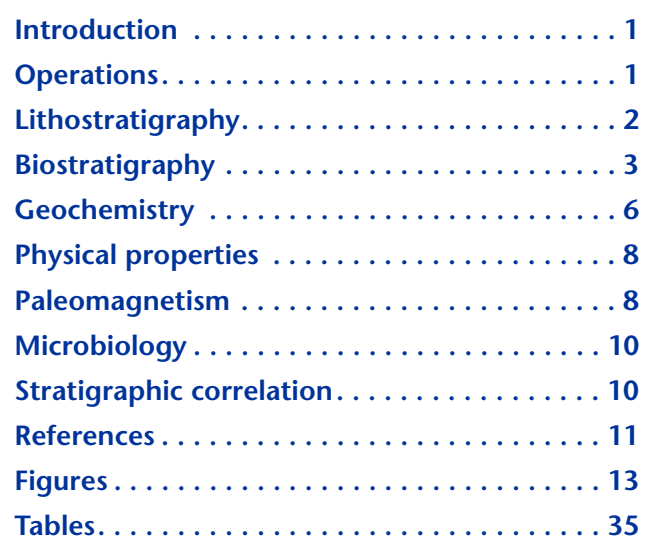

${ }^{1}$ Andrén, T., Jørgensen, B.B., Cotterill, C., Green, S., Andrén, E., Ash, J., Bauersachs, T., Cragg, B., Fanget, A.-S., Fehr, A., Granoszewski, W., Groeneveld, J., Hardisty, D., Herrero-Bervera, E., Hyttinen, O., Jensen, J.B., Johnson, S., Kenzler, M., Kotilainen, A., Kotthoff, U., Marshall, I.P.G., Martin, E., Obrochta, S., Passchier, S., Quintana Krupinski, N., Riedinger, N., Slomp, C., Snowball, I., Stepanova, A., Strano, S., Torti, A., Warnock, J., Xiao, N., and Zhang, R., 2015. Site M0061. In Andrén, T., Jørgensen, B.B., Cotterill, C., Green, S., and the Expedition 347 Scientists, Proc. IODP, 347: College Station, TX (Integrated Ocean Drilling Program).

doi:10.2204/iodp.proc.347.105.2015

'Expedition 347 Scientists' addresses.

\section{Introduction}

During Integrated Ocean Drilling Program (IODP) Expedition 347 , cores were recovered from three holes at Site M0061 (Ångermanälven River estuary), with an average site recovery of $97 \%$. In addition, three shallow gravity (Rumohr) cores were acquired. The water depth was $87.9 \mathrm{~m}$, with no tidal range. Existing data sets, including seismic reflection profiles, were evaluated prior to each site to attempt to guide the initial drilling with an anticipated lithologic breakdown. The total time spent on station was 1.23 days.

\section{Operations}

\section{Transit to Hole M0061A}

The Greatship Manisha left Site M0060 at $1030 \mathrm{~h}$ on 1 October 2013, on route to Site M0061 (proposed Site BSB-10) via Øresund. At $1400 \mathrm{~h}$, the vessel slowed while a small crew vessel came alongside to deliver drill supplies and offload microbiology "live" samples. A pilot boarded the Greatship Manisha at $0755 \mathrm{~h}$ on 4 October, guiding the vessel through the Ångermanälven River estuary, arriving at Hole M0061A by $1000 \mathrm{~h}$.

\section{Hole M0061A}

Operations commenced as soon as the vessel had established position and built the dynamic positioning (DP) model (Table T1). Ten piston cores were recovered to deck before the evening of 4 October 2013. Initially, seawater was used for pumping, but because of the presence of sand, Guar gum drill mud was used deeper than 20.0 meters below seafloor (mbsf). At $2220 \mathrm{~h}$, a hammer sample was collected, which retrieved a sample of granite. The hole was terminated at $25.20 \mathrm{mbsf}$ at $2300 \mathrm{~h}$ on 4 October.

A total of 11 coring attempts were made in Hole M0061A to a maximum depth of 25.20 mbsf. Hole recovery was $94.87 \%$.

\section{Hole M0061B}

The vessel moved to establish position for Hole M0061B under DP. At $2340 \mathrm{~h}$, operations commenced with the first core recovered to deck at $0000 \mathrm{~h}$ on 5 October 2013. 
At $0506 \mathrm{~h}$, the tool became stuck. Following release of the overshot and flushing, the tool was freed and coring continued.

Nine piston cores were recovered during the morning of 5 October, reaching a maximum depth of 28.70 mbsf. As with Hole M0061A, the recovery of sand and silt led to the termination of the hole, and the vessel prepared to move to Hole M0061C at 0645 $\mathrm{h}$ on 5 October.

A total of nine coring attempts were made in Hole M0061B, reaching a maximum depth of 28.70 mbsf. Hole recovery was $97.98 \%$.

\section{Hole M0061C}

Piston coring operations in Hole M0061C commenced at $0725 \mathrm{~h}$ on 5 October 2013, after the vessel had bumped across under DP. This hole was cored to produce a composite record with the previous holes and ensure an appropriate volume of material was collected to meet future sampling requirements. Consistent with Holes M0061A and M0061B, the hole was terminated upon encountering the sand lithology beneath the varved sequence.

A total of seven piston coring attempts were made in Hole M0061C, reaching a depth of $23.1 \mathrm{mbsf}$. Hole recovery was $98.4 \%$.

\section{Holes M0061K, M0061L, and M0061M}

Three Rumohr cores were also collected at this site on 5 October 2013. The corer was deployed over the starboard side of the vessel using a system of winches. In total, $0.97 \mathrm{~m}$ (Hole M0061K), $0.96 \mathrm{~m}$ (Hole M0061L), and $0.92 \mathrm{~m}$ (Hole M0061M) of sediment was recovered in the attempt to capture the sediment/water interface without disturbance from the landing of the seabed template.

\section{Lithostratigraphy}

Six holes were drilled at Site M0061: Hole M0061A to a total depth of 25.2 mbsf, Hole M0061B to 28.7 mbsf, and M0061C to 23.1 mbsf. Holes M0061KM0061M were Rumohr cores $(<1 \mathrm{~m}$ penetration gravity cores) designated for microbiology and paleoceanographic sampling. The Rumohr cores were not included in the core description at the IODP Bremen Core Repository (Germany).

Piston coring was the primary coring method used in Holes M0061A-M0061C, with the exception of the bottom of Hole M0061A, where it became difficult to retrieve core as the sediment became sandier and coring changed to hammer sampling. At the base of that hole, a hard layer was reached where only a granite rock $\sim 5 \mathrm{~cm}$ in diameter was recovered (see "Operations"). The cores are slightly to moderately disturbed, and in Unit IV, the sediment was waterlogged and deformed, which prevented the clear identification of internal structures. Lithostratigraphic subdivisions are based on descriptions on the cut face of the split core from Hole M0061A with a core recovery of nearly $95 \%$ and supplemented by information from Holes M0061B and M0061C. Because of time constraints, only a small number of smear slides from core catchers were examined, and the data should be treated with caution because of core disturbance and contamination affecting core catcher material in general.

Site M0061 is divided into four lithostratigraphic units (Fig. F1). Unit I (0-2.30 mbsf; Hole M0061A) is composed of greenish black organic-rich clay influenced by expanding methane. A gradual transition is observed to Unit II, which is divided into Subunit IIa (2.30-6.46 mbsf; Hole M0061A), a dark greenish gray weakly varved clay with weak sulfide banding, Subunit IIb (6.46-6.90 mbsf; Hole M0061A), a downhole continuation of Subunit IIa dominated by black laminae rich in iron sulfide, and Subunit IIc (6.90-8.10 mbsf; Hole M0061A), which is gray clay. Unit III (8.10-14.50 mbsf; Hole M0061A) is dark greenish gray clayey silt with a varvic, rhythmic lamination that gradually grades to the dark gray silty sand and fine sands of Unit IV (14.50-28.70 mbsf; Hole M0061B). Unit IV also contains limited numbers of dispersed pebble-sized clasts.

\section{Unit I}

Intervals: $347-\mathrm{M} 0061 \mathrm{~A}-1 \mathrm{H}-1,0 \mathrm{~cm}$, to $2 \mathrm{H}-1,80$ $\mathrm{cm}$; 347-M0061B-1H-1, $0 \mathrm{~cm}$, to $1 \mathrm{H}-2,90 \mathrm{~cm}$; $347-\mathrm{M} 0061 \mathrm{C}-1 \mathrm{H}-1,0 \mathrm{~cm}$, to $1 \mathrm{H}-2,94 \mathrm{~cm}$

Depths: Hole M0061A $=0-2.30$ mbsf; Hole M0061B $=0-2.40$ mbsf; Hole M0061C $=0-2.44$ mbsf

Unit I is chiefly composed of a greenish gray to black clay that is only slightly disturbed with good recovery. The uppermost $40 \mathrm{~cm}$ is mostly greenish gray, becoming blacker downhole, marking increasing organic matter contribution. The clay comprises weak lamination, with millimeter-scale black laminae and spots, often smeared as a result of the core splitting process. Possible bioturbation is present at some intervals but is often very faint. The clay is very well sorted, with small voids due to methane expansion dispersed along the upper half of the unit especially. Smear slide studies (see "Core descriptions") show that the terrigenous components consist of $90 \%$ silt and only 5\% sand, as well as clay with a composition dominated by quartz, limited feldspar, and traces of biotite. 
Black organic-rich clay with indistinct varves likely signifies deposition in conditions similar to a brackish-marine environment. Visible black banding is likely due to diagenetic sulfidization linked to organic accumulation during events of lower oxygen content.

\section{Unit II}

\section{Subunit Ila}

Intervals: 347-M0061A-2H-1, $80 \mathrm{~cm}$, to $3 \mathrm{H}-2,16$ $\mathrm{cm}$; 347-M0061B-1H-2, $90 \mathrm{~cm}$, to $3 \mathrm{H}-1,20 \mathrm{~cm}$; 347-M0061C-1H-2, $94 \mathrm{~cm}$, to $3 \mathrm{H}-1,90 \mathrm{~cm}$

Depths: Hole M0061A $=2.30-6.46$ mbsf; Hole M0061B $=2.40-6.30$ mbsf; Hole M0061C = 2.44-7.50 mbsf

\section{Subunit IIb}

Intervals: $347-\mathrm{M} 0061 \mathrm{~A}-3 \mathrm{H}-2,16 \mathrm{~cm}$, to $3 \mathrm{H}-2,60$ $\mathrm{cm}$; 347-M0061B-3H-1, $20 \mathrm{~cm}$, to $3 \mathrm{H}-1,70 \mathrm{~cm}$; 347-M0061C-3H-1, $90 \mathrm{~cm}$, to $3 \mathrm{H}-1,1.40 \mathrm{~cm}$

Depths: Hole M0061A $=6.46-6.90$ mbsf; Hole M0061B = 6.30-6.80 mbsf; Hole M0061C = 7.50-8.00 mbsf

\section{Subunit Ilc}

Intervals: $347-\mathrm{M} 0061 \mathrm{~A}-3 \mathrm{H}-2,60 \mathrm{~cm}$, to $4 \mathrm{H}-1,0$ $\mathrm{cm}$; 347-M0061B-3H-1, $70 \mathrm{~cm}$, to $3 \mathrm{H}-2,30 \mathrm{~cm}$; $347-\mathrm{M} 0061 \mathrm{C}-3 \mathrm{H}-1,1.40 \mathrm{~cm}$, to $3 \mathrm{H}-2,64 \mathrm{~cm}$

Depths: Hole M0061A $=6.90-8.10$ mbsf; Hole $\mathrm{M} 0061 \mathrm{~B}=6.80-7.89$ mbsf; Hole $\mathrm{M} 0061 \mathrm{C}=$ 8.00-8.74 mbsf

The upper part of the unit consists of dark greenish gray silty-sandy organic-rich clay with weak gray lamination on millimeter scales, often in $2-5 \mathrm{~cm}$ bundles. Sparse bioturbation is observed, and the sediment is very well sorted. In Subunit IIb, black iron sulfide laminae dominate (Fig. F2). Subunit IIc is a lithologic continuation of the clay in Subunits IIa and IIb, but gray and without the presence of iron sulfide. Smear slide studies (see "Core descriptions") show that the terrigenous components consist of $90 \%$ sand and $10 \%$ silt with a composition dominated by quartz and feldspar and minor contents of biotite.

This fine laminated silty clay with high organic content is interpreted as possible annual sediment laminae (varves) deposited in a localized protected basin. The rhythmic appearance possibly reflects local climatic changes in organic matter accumulation. The black laminated horizon represents increased iron sulfide diagenetic processes within Subunit IIb. This increase may represent periods of low oxygen and increased organic matter deposition, providing sufficient conditions for sulfide formation. The lower- most part (Subunit IIc) is a transition zone in the generally lithologically normal graded fjord sediments.

\section{Unit III}

Intervals: $347-\mathrm{M} 0061 \mathrm{~A}-4 \mathrm{H}-1,0 \mathrm{~cm}$, to $7 \mathrm{H}-1,0 \mathrm{~cm}$; $347-\mathrm{M} 0061 \mathrm{~B}-3 \mathrm{H}-2,30 \mathrm{~cm}$, to $5 \mathrm{H}-2,30 \mathrm{~cm} ; 347-$ M0061C-3H-2, $64 \mathrm{~cm}$, to $5 \mathrm{H}-2,50 \mathrm{~cm}$

Depths: Hole M0061A $=8.10-14.5$ mbsf; Hole $\mathrm{M} 0061 \mathrm{~B}=7.89-14.50$ mbsf; Hole M0061C = 8.74-15.20 mbsf

Unit III comprises dark greenish gray interlaminated clayey silt and silt, rhythmites, and perhaps varves fining upward within one lamina (silt to clay); lamination is visible by changes in grain size and color with a general thickness of laminae around $1-4 \mathrm{~cm}$. The unit is very well sorted and slightly disturbed, gradually grading downhole to the sand of Unit IV.

This fine laminated silty sediment is interpreted as annual sediment laminae (varves) deposited in a locally protected basin. The rhythmic appearance possibly reflects local climatic changes.

\section{Unit IV}

Intervals: 347-M0061A-7H-1, $0 \mathrm{~cm}$, to end of hole; $347-\mathrm{M} 0061 \mathrm{~B}-5 \mathrm{H}-2,30 \mathrm{~cm}$, to end of hole; 347M0061C-5H-2, $50 \mathrm{~cm}$, to end of hole

Depths: Hole M0061A = 14.50-25.2 mbsf; Hole M0061B = 14.50-28.7 mbsf; Hole M0061C = 15.20-23.10 mbsf

Unit IV consists of dark gray homogeneous silty sand with clayey silt interbeds on a centimeter scale, grading downhole to medium, washed sand containing brown specks (small plant remnants, opaques, and white mica). Grain shapes are subangular to subrounded. A few dispersed gravel clasts are present.

The downhole increase of sand and rare gravel-sized clasts may be evidence for a glacially influenced environment, possibly influenced by meltwater flow.

\section{Biostratigraphy Diatoms}

Qualitative analyses for siliceous microfossils were carried out on 21 samples from Hole M0061A and 4 samples from Hole M0061B with an interval of 1.5 to $3 \mathrm{~m}$ between samples. Diatoms were identified to species level, and ebridians and chrysophyte cysts were recorded if present. The results of the qualitative diatom analyses for both holes are summarized in graphs showing the number of taxa found, divided into different salinity affinities and life forms (planktonic, periphytic, and sea ice) (Figs. F3, F4). 
The occurrence of diatom taxa in studied samples is shown in Tables T2 and T3. A species list of all 97 recorded taxa from Site M0061 is presented in Table T4. Diatoms were classified with respect to salinity tolerance according to the Baltic Sea intercalibration guides of Snoeijs et al. (1993-1998), which divide taxa into five groups: marine, brackish-marine, brackish, brackish-freshwater, and freshwater. The preservation in all slides containing diatoms can be considered good with lightly siliceous taxa still present. Chrysophyte cysts of various morphotypes were present in all slides where diatoms were recorded.

\section{0 to $\sim 2$ mbsf}

The assemblage recorded in this interval reflects a dynamic brackish estuary environment with large river input. The uppermost interval recorded in Hole M0061A has a relatively diverse assemblage (Fig. F3). It is a mixture of freshwater taxa (e.g., periphytic $\mathrm{Ta}$ bellaria flocculosa, Fragilaria exigua, Eunotia implicata, and planktonic species from the genera Aulacoseira and Cyclotella), brackish-freshwater taxa (e.g., periphytic Rhopalodia gibba, Epithemia sorex, Epithemia turgida, Cocconeis pediculus, and planktonic Thalassiosira baltica), and brackish taxa (e.g., periphytic Rhoicosphenia curvata and planktonic Pauliella taeniata and Thalassiosira levanderi). The freshwater taxa in this uppermost interval probably reflect allochthonous river input from Ångermanälven River. The influence of sea ice taxa is observed in this sequence, consisting of $P$. taeniata, Fragilariopsis cylindrus, and Melosira arctica. P. taeniata is an Arctic planktonic sea ice diatom abundant in the entire Baltic Sea area that dominates the spring bloom after cold winters with extensive ice cover (Hajdu et al., 1997; Hasle and Syvertsen, 1990; Snoeijs, 1993-1998; Weckström and Juggins, 2006).

\section{2-6 mbsf}

The diatom assemblage in this interval indicates a brackish water, open-coastal environment with some influence from fluvial input. It was only recorded in one sample from Hole M0061A (4.8 mbsf), so four additional samples from Hole M0061B (2.8-6.1 mbsf) were analyzed to cover this interval (Figs. F3, F4). The assemblage is dominated by brackish (e.g., planktonic Thalassiosira hyperborea var. lacunosa, $T$. levanderi, Cyclotella choctawhatcheeana, P. taeniata, and periphytic $R$. curvata and Cocconeis scutellum) and brackish-marine taxa (e.g., Tabularia fasciculata) but also some marine taxa, especially in the lowermost part (e.g., Pseudosolenia calcar-avis and Opephora marina). Brackish-marine Chaetoceros spp. resting spores are common throughout the sequence. There is also a constant record of $\sim 10 \%-25 \%$ freshwater di- atom taxa most probably reflecting transported river input. The ebridian Ebria tripartita is recorded at all analyzed levels.

\section{6-8 mbsf}

The diatom assemblage at this interval suggests a freshwater (large lake) environment with weak influence of brackish water. The transition from this assemblage (recorded at 6.3 mbsf in Hole M0061A) to a brackish environment (recorded at 6.1 mbsf in Hole M0061B) is not defined and must be investigated further. The sequence was recorded in three samples from Hole M0061A, and the assemblage is dominated by freshwater taxa (e.g., the large lake taxa Stephanodiscus neoastraea, Aulacoseira islandica, Gomphocymbella ancylii, and Cocconeis disculus [Hedenström and Risberg, 1999]), but brackish-freshwater ice algae Fragilariopsis cylindrus was also common in the uppermost sample (6.3 mbsf) (Fig. F3).

\section{6 mbsf to bottom of core}

This interval is more or less barren of siliceous microfossils; only single frustules and fragments of diatoms and one Chrysophyte cyst were found (Fig. F3).

\section{Foraminifers}

Results are summarized for the samples taken offshore and onshore (i.e., samples taken from core catchers and regular sections). A total of 50 samples were processed and scanned from Holes M0061A, $\mathrm{M} 0061 \mathrm{~B}$, and M0061C for the presence of foraminifers (Table T5). Foraminifers were previously not recorded for the Bothnian Sea and its estuaries. This is possibly due to the very low salinity in this part of the Baltic Sea, as bottom water salinity in the Ångermannälven River estuary is around 5 (Samuelsson, 1996). Past reconstructions of salinity based on $\mathrm{Sr}$ isotopes of mollusk shells suggested that during the middle Holocene salinity might have been as high as 10-12 in the Bothnian Sea, allowing a foraminiferal community to become established (Widerlund and Andersson, 2011).

Site M0061 cores contain significant benthic foraminifers for selected samples (Fig. F5). All foraminifers belong to a single species, Elphidium albiumbilicatum. E. albiumbilicatum is able to survive under very low salinity conditions (Rottgardt, 1952; Lutze, 1965). Foraminifers are found between 1.69 and 6.23 mbsf with a maximum abundance classified as "common" in the core catcher sample from Core 347-M0061C-1H (Fig. F5). The occurrence of foraminifers at Site M0061 can potentially be linked to the slightly higher salinity conditions that are reconstructed for the middle Holocene (Widerlund and 
Andersson, 2011). However, foraminifers were not present in every sample in this interval. This might be related to a combination of the dynamic setting within the estuary and the low salinity such that conditions were not continuously appropriate for foraminifers to form a population. As such, the presence of foraminifers is only appointed to specific samples instead of to a certain interval.

\section{Ostracods}

Ostracods were examined from 49 samples (including 23 core catchers) from Holes M0061A, M0061B, and M0061C during the onshore phase of Expedition 347 at the Bremen Core Repository. Samples were studied in the $>125 \mu \mathrm{m}$ fraction. Ostracods were present in eight samples (Table T6).

Ostracod abundance per sediment volume from the three holes was low and is shown in Figure F6. Four species were identified: Hirschmania viridis, Paracyprideis fennica, Sarsicytheridea punctillata, and Heterocyprideis sorbyana.

$P$. fennica is the most common species at this site, occurring in the interval 0.17-4.45 mbsf (Holes M0061A-M0061C). Deeper, at 5.11 mbsf (Core 347M0061A-3H-1, 30-32 cm), only one species, H. viridis, was recorded. The interval immediately deeper, to 28.68 mbsf (Holes M0061A-M0061C), was barren. Similarly, foraminifers were only found from 1.69 to 6.23 mbsf (see "Foraminifers"). The highest number of ostracods was recorded at 2.82 mbsf (Hole M0061B) (Table T6) in the only sample where $S$. punctillata and $H$. sorbyana were recorded.

Such low abundance and taxonomic diversity implies harsh environments for ostracods. P. fennica, $S$. punctillata, and $H$. sorbyana are all known to tolerate a wide range of salinities from 4 to fully marine conditions; P. fennica can also be found in low-oxygen environments (Frenzel et al., 2010). Low salinity is not a limiting factor for ostracod abundance, as many taxa tolerate fresh and brackish water environments, but similarity between ostracod and foraminifer records implies that salinity decreases toward the uppermost samples. Another important factor is the very high sedimentation rates that decrease in the upper part of the record (see "Lithostratigraphy"), allowing microfossils to be preserved.

\section{Palynological results}

For Site M0061, palynological analyses focused on Hole M0061B. Generally, one sample per core was examined for palynomorphs. Today, the regional vegetation in the terrestrial area around Site M0061 is dominated by pine (Pinus), birch (Betula), and spruce (Picea) trees and belongs to the boreal-forest vegetation zone with taiga-like conditions.

Nine sediment samples were analyzed from Hole M0061B. The uppermost four samples contained enough palynomorphs to get statistically relevant results (Figs. F7, F8). Bisaccate pollen was included in the reference sum, but at least 50 nonsaccate pollen grains were counted per sample in order to cope with the high percentages of bisaccate pollen.

\subsection{3-6.62 mbsf}

Pollen concentrations are between $\sim 40,000 / \mathrm{cm}^{3}$ and $\sim 180,000 / \mathrm{cm}^{3}$ in the four samples analyzed from this interval (see PalyM0061.xls in PALYNOLOGY in "Supplementary material"). Pinus is the dominant pollen taxon in all samples. The second most frequent pollen type in most samples is Betula pollen. The two uppermost samples analyzed show some difference compared to the two deeper samples. Picea (spruce) pollen shows percentages up to $17 \%$ in the two uppermost samples ( 0.13 and 1.53 mbsf; Fig. F7). It is accepted that spruce arrived at the SwedishBothnian coast around 3500 cal y BP (Huntley and Birks, 1983; Segerström and von Stedingk, 2003). This would imply that the age of the sample at 1.53 mbsf dates to at least 3500 y BP. Worthy of mention here is the presence of Betula nana pollen, a dwarf birch growing under arctic and cool temperate climatic conditions (for instance, central and northern Sweden). The two uppermost samples are also characterized by the high-frequency presence of Radiosperma corbiferum (Fig. F8), a dubious taxon which has so far been described as an acritarch, mollusk egg, or algal cyst (also called "Sternhaarstatoplast," e.g., Nehring, 1994). Picea is virtually absent in the deeper samples from this interval (4.42 and 6.26 mbsf). In some samples, pteridophyte spores are also common, with recurrent presence of Dryopteris (wood fern), particularly in the sample from 6.26 mbsf. Dinocysts and other marine palynomorphs were extremely rare in these samples, except for one sample at 4.42 mbsf that contained several specimens of Operculodinium centrocarpum/Protoceratium reticulatum. All of them have particularly short processes, which may indicate low salinity (Mertens et al., 2009). This finding is congruent with foraminifer-based results, which indicate a slightly stronger marine influence between 3.40 and 4.90 mbsf indicated by slightly increased abundances of foraminifers (genus Elphidium) and lower frequency/absence of foraminifers shallower than these depths. Generally, the rarity of marine taxa in this interval points to a strong terrestrial influence, with particularly low influence in the upper samples. 


\section{0-26.15 mbsf}

Five samples from this interval were analyzed, but none of them contained enough pollen to generate statistically relevant results. Most samples were completely barren of palynomorphs. This is in accordance with sedimentological findings, which indicate that the samples originate from silty/sandy sediments. Thus, palynomorphs either occur in very low concentration in this material or were completely degraded because of oxidation.

\section{Geochemistry}

At Site M0061, silty and sandy sediments are overlain by $\sim 8$ m of clays (see "Lithostratigraphy"). The geochemical concentration profiles at Site M0061 reflect strong variations in depositional conditions in the outer Ångermanälven River estuary.

\section{Interstitial water}

\section{Salinity variations: chloride, salinity, and alkalinity}

Chloride $\left(\mathrm{Cl}^{-}\right)$concentrations are lowest at the top of the profile with values around $100 \mathrm{mM}$ and increase to $\sim 130 \mathrm{mM}$ at $8 \mathrm{mbsf}$ (Fig. F9A). Deeper concentrations are almost constant with a slight decrease of 3$4 \mathrm{mM}$ between 15 and 20 mbsf. Shipboard salinity measured with a refractometer ranges $\sim 6-10$ and shows the same general depth trend as $\mathrm{Cl}^{-}$based salinity (Fig. F9B-F9C). Shipboard salinity values for Hole M0061C are higher than those for Holes M0061A and M0061B; however, $\mathrm{Cl}^{-}$based salinities for all holes are very similar (Fig. F9C; Table T7). The salinity concentration profiles show freshwater impact in the surface sediments, likely related to fluvial input.

Alkalinity increases from $13.5 \mathrm{meq} / \mathrm{L}$ in the uppermost sample to $\sim 20 \mathrm{meq} / \mathrm{L}$ at $5.5 \mathrm{mbsf}$ followed by a gradual decrease to $\sim 6 \mathrm{meq} / \mathrm{L}$ at the core bottom (Fig. F9D).

\section{Organic matter degradation: sulfate, sulfide, ammonium, phosphate, iron, manganese, $\mathrm{pH}$, bromide, and boron}

Sulfate $\left(\mathrm{SO}_{4}{ }^{2-}\right)$ concentrations from Hole M0061C remain $<0.25 \mathrm{mM}$ until $\sim 16 \mathrm{mbsf}$, where there is a gradual increase to $2.8 \mathrm{mM}$ at $21 \mathrm{mbsf}$ (Fig. F10A). In Holes M0061A and M0061B, $\mathrm{SO}_{4}{ }^{2-}$ concentrations remain below detection until 21 mbsf and then gradually rise to $3.8 \mathrm{mM}$ by $27 \mathrm{mbsf}$. The overall similarity of the $\mathrm{SO}_{4}{ }^{2-}$ profiles of the three holes suggest that contamination by drilling fluid is probably negligible and the measured $\mathrm{SO}_{4}{ }^{2-}$ in the deeper sediment intervals may be provided by a subsurface source or a lateral inflow of sulfate-rich waters into the sandy deposits (see "Lithostratigraphy").

Pore water sulfide $\left(\mathrm{H}_{2} \mathrm{~S}\right)$ was detected only in the uppermost sediment sequence $(<8 \mathrm{mbsf})$ with values not exceeding $5 \mu \mathrm{M}$ (Fig. F10B). The downhole trend in ammonium $\left(\mathrm{NH}_{4}^{+}\right)$is similar to that of alkalinity (Fig. F10C). Values increase from $0.5 \mathrm{mM}$ in the uppermost sample to a maximum value of $1.3 \mathrm{mM}$ at $\sim 6$ mbsf before gradually decreasing downhole to $0.24 \mathrm{mM}$ by 27 mbsf. The phosphate $\left(\mathrm{PO}_{4}{ }^{3-}\right)$ concentration profile shows an increase from $0.4 \mathrm{mM}$ in the uppermost sample to a peak of $0.6 \mathrm{mM}$ by $2.5 \mathrm{mbsf}$ (Fig. F10D). Deeper than this maximum, concentrations slowly decline to values of $1-2 \mathrm{mM}$ by $\sim 8-10$ mbsf and below detection by 22 mbsf. These results indicate high rates of organic matter degradation in the upper $\sim 8 \mathrm{~m}$ of the core.

Dissolved iron $\left(\mathrm{Fe}^{2+}\right)$ and manganese $\left(\mathrm{Mn}^{2+}\right)$ concentrations are elevated near the sediment surface $(95$ and $250 \mu \mathrm{M}$, respectively), followed by a zone of depletion with the lowest values around 5 mbsf for both cations (Fig. F10E-F10F). Iron concentrations then increase to $\sim 350 \mu \mathrm{M}$ by $12 \mathrm{mbsf}$, followed by a gradual decrease to $<100 \mu \mathrm{M}$ at the bottom of the profile. Manganese concentrations gradually rise to $\sim 120 \mu \mathrm{M}$ by $15 \mathrm{mbsf}$ and then decline to $\sim 60 \mu \mathrm{M}$ at 27 mbsf.

$\mathrm{pH}$ is characterized by some variation in the uppermost sediment sequence ( $<8 \mathrm{mbsf})$ but generally shows similar trends between holes (Fig. F10G). There is an increase from 7.8 in the uppermost sample to a peak of $\sim 8$ between 6 and 8 mbsf. Deeper $\mathrm{pH}$ values decline to near 7.6 by 12 mbsf and remain fairly constant for the remainder of the sampled interval.

The profile for bromide $\left(\mathrm{Br}^{-}\right)$largely follows the salinity profile with an increase from 0.16 to $0.21 \mathrm{mM}$ in the upper 6-7 mbsf. Deeper $\mathrm{Br}^{-}$concentrations show little variation downcore (Fig. F11A). There are only small variations in the $\mathrm{Br} / \mathrm{Cl}$ ratio (Fig. F11B). The low $\mathrm{Br}^{-}$concentrations together with low alkalinity values suggest low rates of organic matter degradation at this site. Boron (B) concentrations show a maximum of $\sim 140 \mu \mathrm{M}$ at $\sim 4 \mathrm{mbsf}$, followed by a decrease downhole and the absence of $\mathrm{B}$ deeper than $\sim 20$ mbsf (Fig. F11C). The $\mathrm{B} / \mathrm{Cl}$ ratio is elevated above the seawater ratio and peaks at $4 \mathrm{mbsf}$, and then the ratio drops gradually to approach zero deeper than $\sim 20$ mbsf (Fig. F11D). 


\section{Mineral reactions}

\section{Sodium, potassium, magnesium, and calcium}

Sodium $\left(\mathrm{Na}^{+}\right)$, potassium $\left(\mathrm{K}^{+}\right)$, and magnesium $\left(\mathrm{Mg}^{2+}\right)$ concentrations all increase with depth in the upper 5-8 mbsf (Fig. F12A-F12C). Deeper concentrations of $\mathrm{Na}^{+}$and $\mathrm{K}^{+}$gradually decline to $\sim 75$ and 1.3 $\mathrm{mM}$, respectively, toward the base of the profile. Magnesium concentrations increase from $9 \mathrm{mM}$ at the top to $\sim 13 \mathrm{mM}$ at $5 \mathrm{mbsf}$, decrease to $10 \mathrm{mM}$ at 15 mbsf, and then rise again to $\sim 13 \mathrm{mM}$ at the bottom of Holes M0061A and M0061B. Note that $\mathrm{Mg}^{2+}$ concentrations remain near constant in the lower part of Hole M0061C (Fig. F12C). Calcium $\left(\mathrm{Ca}^{2+}\right)$ concentrations increase steadily with depth from $\sim 2.3$ in the upper section to $\sim 24 \mathrm{mM}$ at $27 \mathrm{mbsf}$ (Fig. F12D). The ratios of $\mathrm{Na} / \mathrm{Cl}$ and $\mathrm{K} / \mathrm{Cl}$ indicate that both $\mathrm{Na}^{+}$and $\mathrm{K}^{+}$are depleted relative to seawater ratios in sediments deeper than 10 mbsf (Fig. F12EF12F). $\mathrm{Mg} / \mathrm{Cl}$ ratios are near constant (Fig. F12G), whereas those of $\mathrm{Ca} / \mathrm{Cl}$ increase with depth (Fig. F12H). The high $\mathrm{Ca}^{2+}$ and $\mathrm{Mg}^{2+}$ concentrations between 10 and 22 mbsf in Hole M0061C compared to Holes M0061A and M0061B are not balanced by an equivalent concentration of anions. This suggests that the data for Hole M0061C should be viewed with caution.

The $\mathrm{Ca}^{2+}$ concentration profiles from all three holes clearly show release of $\mathrm{Ca}^{2+}$ from sediments. In combination with the $\mathrm{Ca} / \mathrm{Cl}$ ratios, which display a gradual increase downcore, the $\mathrm{Ca}^{2+}$ data indicate a source of calcium in deeper subsurface sediments, including potential $\mathrm{Ca}^{2+}$ displacement from solid phases at depth by $\mathrm{Na}^{+}$and $\mathrm{K}^{+}$through ion exchange and/or dissolution of Ca-bearing phases.

\section{Strontium, lithium, silica, and barium}

The strontium $\left(\mathrm{Sr}^{2+}\right)$ concentration profile is similar to that of $\mathrm{Ca}^{2+}$. Concentrations increase from $16 \mu \mathrm{M}$ in the topmost pore water samples to $68 \mu \mathrm{M}$ at the bottom of the profile (Fig. F13A).

Lithium $\left(\mathrm{Li}^{+}\right)$concentrations increase from $\sim 5 \mu \mathrm{M}$ in the uppermost section to $8.6 \mu \mathrm{M}$ near $5 \mathrm{mbsf}$ (Fig. F13B). Deeper concentrations decrease to a value of $\sim 3 \mu \mathrm{M}$ at 9 mbsf and then increase again to an average value close to $10 \mu \mathrm{M}$ at the base of the profile.

Dissolved silica $\left(\mathrm{H}_{4} \mathrm{SiO}_{4}\right)$ concentrations are elevated in the upper 8 mbsf with a concentration near 700 $\mu \mathrm{M}$ (Fig. F13C). Deeper, there is an abrupt drop of $\mathrm{H}_{4} \mathrm{SiO}_{4}$ close to $340 \mu \mathrm{M}$. Concentrations remain constant for the remainder of the profile. This trend may relate to a dissolution of diatoms, which are present in the upper 8 mbsf (see "Biostratigraphy").

Barium $\left(\mathrm{Ba}^{2+}\right)$ concentrations increase with depth from $0.4 \mu \mathrm{M}$ near the surface to $\sim 15-20 \mu \mathrm{M}$ around 15 mbsf (Fig. F13D). Deeper than this peak, values gradually decrease to the bottom of the profile. Hole M0061C again shows distinct variation from Holes M0061A and M0061B. The $\mathrm{Ba}^{2+}$ enrichment with depth may be explained by $\mathrm{Ba}^{2+}$ desorption, weathering reactions, or dissolution of barium-containing minerals, which is enhanced when interstitial water sulfate is low.

\section{Molybdenum, vanadium, and titanium}

Molybdenum (Mo) and vanadium (V) are highly variable in concentration with depth and between holes (Table T8). Mo concentrations are relatively constant (e.g., $0.04 \mu \mathrm{M}$ ) in the upper $10 \mathrm{mbsf}$, followed by a maximum value directly deeper (up to $0.15 \mu \mathrm{M})$ and a decline toward the base of the profile. $\mathrm{V}$ concentrations, in contrast, decrease from $0.18 \mu \mathrm{M}$ near the surface to values $<0.1 \mu \mathrm{M}$ deeper than 10 mbsf. Dissolved titanium (Ti) concentrations show a small but distinct trend consistent between holes in the uppermost sediments (Table T8). Concentrations of $\sim 0.23 \mu \mathrm{M}$ are observed at the core top, followed by a constant decline to values $<0.01 \mu \mathrm{M}$ around 9 mbsf.

\section{Sediment}

\section{Carbon content}

Sedimentary total carbon (TC) values (Fig. F14A; Table T9) reach a maximum of $\sim 2.6 \mathrm{wt} \%$ in the upper 4-5 mbsf and then decrease to values below $0.2 \mathrm{wt} \%$ at 10 mbsf. The total organic carbon (TOC) profile largely resembles the one of $\mathrm{TC}$, indicating that the majority of carbon is organic (Fig. F14B). The content of total inorganic carbon (TIC) in these sediments is low throughout the sediment column, with only slightly elevated concentrations (up to 0.25 wt\%) in the upper $\sim 8$ mbsf (Fig. F14C).

\section{Sulfur content}

Total sulfur (TS) concentrations (Fig. F14D) follow the trend of the TOC profile with a maximum value of $2.3 \mathrm{wt} \%$ at the depth of the TOC maximum $(\sim 4.5$ mbsf). Contents of TS decrease to low values $(<0.2$ $\mathrm{wt} \%$ ) deeper than the maximum to $\sim 8 \mathrm{mbsf}$ and stay low downcore. The high TOC and TS concentrations coincide with black bands described in the clays of lithostratigraphic Subunit IIb (see "Lithostratigra- 
phy") and are likely related to the presence of metal sulfide minerals in these sediment layers.

\section{Physical properties}

This section summarizes the preliminary physical property results from Site M0061. Three holes were drilled at this site. Hole M0061A was drilled to 25.2 mbsf, Hole M0061B to 28.7 mbsf, and Hole M0061C to $23.1 \mathrm{mbsf}$. Additionally, three Rumohr cores (Holes M0061K, M0061L, and M0061M; <1 $\mathrm{m}$ in length) were collected at this site to attempt to capture the water/sediment interface and the uppermost surface sediments. Physical property measurements were not performed for these Rumohr cores. For Holes M0061A, M0061B, and M0061C, all physical property measurements described in "Physical properties" in the "Methods" chapter (Andrén et al., 2015a) were conducted. As the discrete moisture and density (MAD) and $P$-wave measurements are few in number, our interpretations are based primarily on the shipboard multisensor core logger (MSCL) data from Hole M0061B, which had the greatest penetration.

\section{Magnetic susceptibility and color reflectance}

Magnetic susceptibility generally increases downcore with distinct variations noted at lithostratigraphic unit boundaries (Fig. F15). Values are relatively constant through Unit I, with a low-amplitude excursion at the Unit I/Subunit IIa boundary followed by a gradual decrease in the upper interval of Subunit IIa. Magnetic susceptibility then increases downcore in Subunit IIa before dropping to low values in Subunit IIb and returning to high values in Subunit IIc. Lithology is similar throughout Unit II. Therefore, the change in magnetic susceptibility likely reflects changing organic content (see "Lithostratigraphy"). Unit III is characterized by increasing magnetic susceptibility to the Unit IV boundary. Unit IV exhibits relatively constant values with some large excursions around 22 and 26 mbsf.

Color reflectance, in particular $\mathrm{b}^{*}$, reflects downcore changes in lithology (Fig. F15). Unit I exhibits relatively low (more blue) values, whereas Subunit IIa exhibits higher (more yellow) values. Subunit IIb is distinguished by increased blue reflectance, whereas Subunit IIc is characterized by increased yellow reflectance. Units III and IV are generally yellowish in color.

\section{Natural gamma ray, noncontact resistivity, and $P$-wave velocity}

Both natural gamma ray (NGR) and noncontact resistivity (NCR) increase through Units I and II, reaching peak values in the upper interval of Unit III (Fig. F15). There is a sharp decrease in both physical properties at $~ 9$ mbsf in Unit III. That change could be related to a suggested erosional horizon at around that level (see "Stratigraphic correlation"). Although NGR returns to high values in the middle portion of Unit III, NCR remains low to the bottom of the hole. A similar trend in NGR data is observed at nearby Site M0062, located in Ångermanälven River estuary (see "Physical properties" in the "Site M0062" chapter [Andrén et al., 2015b]). Low NCR may indicate high water content in the cores, which is consistent with $P$-wave velocities in Unit IV that vary around $\sim 1500 \mathrm{~m} / \mathrm{s}$ (speed in water). In the upper sections of Hole M0061B, low $P$-wave velocities in Subunit IIa are likely caused by pervasive cracks. Low $P$ wave velocity spikes in portions of Units III and IV appear to result from core liners that were not fully filled with sediment.

\section{Density}

Gamma density was measured at $1 \mathrm{~cm}$ intervals during the offshore phase of Expedition 347 (Fig. F16). Gamma density increases from the core top to the upper interval of Unit III then decreases abruptly at $~ 11$ mbsf before increasing again and remaining relatively constant to the bottom of the hole. Discrete bulk density measurements conducted during the Onshore Science Party (OSP) correlate well with the shipboard measurements $\left(r^{2}=0.93\right.$; Fig. F17).

\section{Paleomagnetism}

To fulfill the main objectives of the OSP paleomagnetic work, we carried out basic analyses of the natural remanent magnetization (NRM) and magnetic susceptibility of discrete specimens of known volume and mass magnetic susceptibility (see "Paleomagnetism" in the "Methods" chapter [Andrén et al., 2015a]). A total of 309 discrete samples were taken from Holes M0061A (128 samples), M0061B (53 samples), and M0061C (128 samples) according to the site splice, with a higher density of sampling in the upper $11.5 \mathrm{~m}$. Magnetic susceptibility $(\chi)$ ranges between $0.1 \times 10^{-6}$ and $1.4 \times 10^{-6} \mathrm{~m}^{3} / \mathrm{kg}$ through the sequence, with the highest value found 
at the boundary between Subunits IIb and IIa, which is characterized by black (iron sulfide) staining.

Most of the paleomagnetic pilot samples recovered from Units IV and III carried a relatively intense NRM that reached $380 \times 10^{-3} \mathrm{~A} / \mathrm{m}$. This NRM was easily demagnetized and has low magnetic stability. In addition, this relatively coarse sand interval has very scattered inclinations, with an average close to $15^{\circ}$. At 11.5 meters composite depth (mcd) (in Unit III), the NRM intensity decreases and the inclination increases to approach a geocentric axial dipole (GAD) prediction. An interval of high NRM intensity at the boundary between Subunits IIb and IIa is associated with observations of iron sulfide precipitation. The majority of samples in the top part of Unit III and Units II and I carried normal polarity NRMs, with secular variations around the GAD prediction. Pilot samples with relatively high $\chi$ taken from Unit IV and up to the middle of Unit III (11.5 mcd) acquired gyroremanent magnetization (GRM) during alternating field (AF) demagnetization above $50 \mathrm{mT}$, and these samples are associated with inclinations that approach the GAD prediction of $74^{\circ}$. The acquisition of a GRM indicates the presence of authigenic greigite $\left(\mathrm{Fe}_{3} \mathrm{~S}_{4}\right)$, which is responsible for secondary chemical remanent magnetizations of strictly unknown age (Snowball, 1997). The upper $6 \mathrm{~m}$ (part of Subunit IIa and Unit I) contains inclination data that can be correlated to features in a regional master curve (Snowball et al., 2007), but these require independent corroboration.

\section{Discrete sample measurements}

A total of 309 discrete samples were obtained from Holes M0061A, M0061B, and M0061C. Samples were recovered at intervals of $\sim 50 \mathrm{~cm}$ from within the site splice.

\section{Magnetic susceptibility}

The results of the magnetic analyses are shown in Figure F18. Magnetic susceptibility $(\chi)$, which was normalized to sample mass, predominantly ranges between $0.1 \times 10^{-6}$ and $0.6 \times 10^{-6} \mathrm{~m}^{3} / \mathrm{kg}$, with one outlier at $1.4 \times 10^{-6} \mathrm{~m}^{3} / \mathrm{kg}$. Samples taken within Unit IV have $\chi$ values between $0.2 \times 10^{-6}$ and $0.4 \times$ $10^{-6} \mathrm{~m}^{3} / \mathrm{kg}$. Overlying Unit III has relatively lower $\chi$ values that generally do not exceed $0.3 \times 10^{-6} \mathrm{~m}^{3} / \mathrm{kg}$, with the exception of some high values $\left(0.6 \times 10^{-6}\right.$ $\mathrm{m}^{3} / \mathrm{kg}$ ) around 9 and 11 mbsf. Unit II has variable $\chi$, and Subunit IIb is characterized by values of $<0.2 \times$ $10^{-6} \mathrm{~m}^{3} / \mathrm{kg}$. Unit I, which is organic-rich laminated clay, has $\chi$ values close to $0.2 \times 10^{-6} \mathrm{~m}^{3} / \mathrm{kg}$.

Sediment wet density and $\chi$ are positively related, although the majority of the data are from the upper
$11.5 \mathrm{~m}$ because of the higher sampling density in the upper part of the sequence. One significant observation is that shallow positive $\left(<40^{\circ}\right)$ and negative inclinations are associated with a wide range of NRM intensity.

\section{Natural remanent magnetization and its stability}

Results of the pilot sample demagnetization (Fig. F19) indicate that a low AF of $5 \mathrm{mT}$ is sufficient to remove a weak viscous remanent magnetization (VRM). Three different responses to the sequential AF demagnetization are displayed by samples from Site M0061. Category 1 includes the samples from the relatively coarse grained Units IV and III, which lose $50 \%$ of their NRM intensity at alternating fields less than $15 \mathrm{mT}$, with a small residual component left at $40 \mathrm{mT}$. These samples subsequently acquired a gyroremanent magnetization (GRM) at field levels $>60 \mathrm{mT}$, with the vector moving into a plane perpendicular to the last demagnetization axis. Category 2, which includes all other pilot samples except those in Unit I, is typified by a paleomagnetic vector that is smoothly demagnetized up to the maximum AF demagnetization level of $80 \mathrm{mT}$, with a vector that trends toward the origin of the orthogonal projection. Category 3 has a relatively high magnetic stability, with $>50 \%$ of the NRM removed between 15 and $30 \mathrm{mT}$, which can indicate a narrow magnetic grain size distribution.

After removal of the viscous overprint, the NRM intensity of the samples recovered from Site M0061 lies between $0.07 \times 10^{-3}$ and $380 \times 10^{-3} \mathrm{~A} / \mathrm{m}$ and there is a general positive relationship with $\chi$ (Fig. F18). It is notable that the NRM intensity of Unit I and the interval of distinct iron sulfide precipitation between Subunits IIb and IIa is particularly high relative to $\chi$, which suggests a more efficient recording of the geomagnetic field than in the other units.

\section{Paleomagnetic directions}

The directions of the subsample paleomagnetic vectors are illustrated by the inclination data in Figure F18. The inclination data from Unit IV and the lower part of Unit III are scattered, with the majority of the inclination values on the positive side of the diagram. Only a few samples from these two units approach the GAD prediction for this site location. In contrast, the inclination data from Units I and II and the uppermost part of Unit III group closer to the GAD prediction, but there is a bias toward shallow inclinations, particularly between 10 and 9 mbsf. It is notable that the samples taken from the upper part of Unit IV and Unit III, which have high $\chi$ val- 
ues, plot relatively far away from the GAD prediction. The variable magnetic properties and different categories of response to AF demagnetization, which include samples that acquire GRM, probably preclude using the paleomagnetic data for relative dating purposes in Units IV and III. In particular, pilot samples that acquire GRM are restricted to intervals with inclinations that are close to the GAD prediction. These samples probably contain a secondary chemical remanent magnetization (CRM) carried by authigenic greigite $\left(\mathrm{Fe}_{3} \mathrm{~S}_{4}\right)$, which is known to acquire GRM (Snowball, 1997). The time lag between sediment deposition and greigite precipitation is unknown and, therefore, the ability to use the paleomagnetic data at Site M0061 for relative dating purposes is most likely restricted to Unit I and the upper half of Unit II, shallower than 5 mbsf. The interval of high inclinations grouped around a depth of $\sim 2 \mathrm{mcd}$ may correspond to one of the late Holocene inclination features identified in the FENNOSTACK regional master curve (Snowball et al. 2007), such as $\varepsilon^{1}(\sim 2650$ cal y BP) or $\gamma(1290 \mathrm{cal}$ y BP).

\section{Microbiology}

A Rumohr core was obtained from Hole M0061K to sample the uppermost $0-1 \mathrm{~m}$ of sediment specifically for cell counts and for onshore microbiology (DNA extraction and analysis). Counts of microbial cells were made on board the ship by fluorescence microscopy only using acridine orange direct count (AODC).

A total of 13 sediment samples were counted for microbial cell numbers on the ship (Table T10) using epifluorescence microscope counting techniques. Microbial cell abundance was very high (Fig. F20), with a maximum of $5.41 \times 10^{9}$ cells $/ \mathrm{cm}^{3}$ at $0.04 \mathrm{mbsf}$ decreasing linearly to a minimum of $6.90 \times 10^{8}$ cells/ $\mathrm{cm}^{3}$ at 0.92 mbsf. This represents approximately an eight-fold decrease in cell numbers over $88 \mathrm{~cm}$. All cell counts of this hole, apart from the uppermost sample at $0.01 \mathrm{mbsf}$, were very high, with all data values above the upper prediction limit of the global regression of prokaryote cells with depth.

\section{Stratigraphic correlation}

At Site M0061, three holes were drilled: M0061A (25.2 mbsf), M0061B (28.7 mbsf), and M0061C (23.1 mbsf). The meters composite depth scale for Site M0061 is based on the correlation of magnetic susceptibility between holes (Fig. F21). Shipboard Fasttrack magnetic susceptibility measurements obtained from every other core were used to determine the offset between adjacent holes (see "Physical properties"). These data provided an efficient tool to monitor and adjust the drilling process in order to maintain an adequate core overlap. All core material was also logged with a standard MSCL to enable more precise hole-to-hole correlation and to construct a composite section for Site M0061 (Fig. F21). Before analysis/correlation, all magnetic susceptibility data were cleaned to remove instrumental outliers. The depth offsets that define the composite section for Site M0061 are given in Table T11 (affine table).

Correlation between the susceptibility anomalies/ data in Holes M0061A, M0061B, and M0061C is good, and it was possible to produce a continuous splice record for this site (Table T12). The splice was constructed mainly from Holes M0061A and M0061C. Hole M0061B was used in the splice to cover larger gaps at 8.5-10 and 14.2-15.3 mcd and in the lowermost part of the splice.

Accuracy of correlation was visually checked from scanned core slab images using the Corelyzer software. At Site M0061, correlation was straightforward to $25 \mathrm{mcd}$. The lowermost $\sim 3 \mathrm{~m}$ of sand lacked distinctive MSCL data or sedimentological features to validate the correlation. A correction for either compression or expansion was not applied to the data, so offsets within each core were equal for all points. Therefore, it is possible that some features are not similarly aligned between holes.

\section{Seismic units}

Seismic sequence boundary-sediment core-MSCL log (magnetic susceptibility) correlations are shown in Figure F22. Correlations are based on the integration of seismic data and lithostratigraphy (see "Lithostratigraphy"). Two-way traveltime values were calculated for each lithostratigraphic unit boundary using sound velocity values measured offshore and during the OSP (see "Physical properties"; Table T13). Lithostratigraphic unit boundaries were examined at the calculated two-way traveltime values to define the extent of agreement between seismic boundaries and actual lithologic transitions and physical properties disconformable surfaces. Uncertainties in the time-depth function may have resulted in minor inconsistencies between seismic features, sedimentological observations from cores, and MSCL logs.

\section{Seismic Unit I}

Two-way traveltime: $0.123 \mathrm{~ms}$

Lithology: greenish gray to black clay (lithostratigraphic Unit I) 
Depths: Hole M0061A $=0-2.30$ mbsf, Hole M0061B $=0-2.40$ mbsf, Hole M0061C $=0-2.44$ mbsf

The Unit I base matches the first clear boundary within a transparent and stratified seismic unit. It is also evident in physical properties, such as low magnetic susceptibility values, measured in sediment cores.

\section{Seismic Unit II}

Two-way traveltime: $0.131 \mathrm{~ms}$

Lithology: dark greenish gray weakly varved clay with weak sulfide banding (lithostratigraphic Subunit IIa); iron sulfide-rich gray clay (lithostratigraphic Subunit IIb); and gray clay (lithostratigraphic Subunit IIc)

Depths: Hole M0061A $=2.30-8.10$ mbsf, Hole M0061B $=2.40-7.89$ mbsf, Hole M0061C $=$ 2.44-8.74 mbsf

Unit II shows increasing magnetic susceptibility values downcore and a distinctive spike related to an iron sulfide clay subunit at $6.46-6.90 \mathrm{mcd}$. In the seismic profile, the lower limit corresponds to a very strong reflector, which could be a basin-wide erosional surface. This strong reflector could possibly be connected to a $\sim 10 \mathrm{~cm}$ thick sandy bed observed between Units II and III (see "Lithostratigraphy").

\section{Seismic Unit III}

Two-way traveltime: $0.140 \mathrm{~ms}$

Lithology: dark greenish gray clayey silt with a varvic rhythmic lamination (lithostratigraphic Unit III)

Depths: Hole M0061A $=8.10-14.50$ mbsf, Hole M0061B = 7.89-14.50 mbsf, Hole M0061C = 8.74-15.20 mbsf

Unit III shows increasing rhythmic variations in downcore magnetic susceptibility values. The lower boundary of seismic Unit III is characterized in the seismic profiles by closely spaced dark reflectors, possibly indicating gradual thickening of rhythmic laminae, and an increase in silt and sand content.

\section{Seismic Unit IV}

Two-way traveltime: $0.159 \mathrm{~ms}$

Lithology: dark gray silty sand and fine sand with a few dispersed pebble-sized clasts (lithostratigraphic Unit IV)

Depths: Hole M0061A $=14.50-25.15$ mbsf, Hole M0061B $=14.50-28.70$ mbsf, Hole M0061C = 15.20-23.10 mbsf

Unit IV is characterized in the seismic images by an upper laminated part and a lower homogeneous part. However, the cores did not reveal this lamina- tion/bedding, as the core liners were in many cases partly filled with water, so original sedimentary structures could not be verified.

\section{References}

Andrén, T., Jørgensen, B.B., Cotterill, C., Green, S., Andrén, E., Ash, J., Bauersachs, T., Cragg, B., Fanget, A.-S., Fehr, A., Granoszewski, W., Groeneveld, J., Hardisty, D., Herrero-Bervera, E., Hyttinen, O., Jensen, J.B., Johnson, S., Kenzler, M., Kotilainen, A., Kotthoff, U., Marshall, I.P.G., Martin, E., Obrochta, S., Passchier, S., Quintana Krupinski, N., Riedinger, N., Slomp, C., Snowball, I., Stepanova, A., Strano, S., Torti, A., Warnock, J., Xiao, N., and Zhang, R., 2015a. Methods. In Andrén, T., Jørgensen, B.B., Cotterill, C., Green, S., and the Expedition 347 Scientists, Proc. IODP, 347: College Station, TX (Integrated Ocean Drilling Program). doi:10.2204/ iodp.proc.347.102.2015

Andrén, T., Jørgensen, B.B., Cotterill, C., Green, S., Andrén, E., Ash, J., Bauersachs, T., Cragg, B., Fanget, A.-S., Fehr, A., Granoszewski, W., Groeneveld, J., Hardisty, D., Herrero-Bervera, E., Hyttinen, O., Jensen, J.B., Johnson, S., Kenzler, M., Kotilainen, A., Kotthoff, U., Marshall, I.P.G., Martin, E., Obrochta, S., Passchier, S., Quintana Krupinski, N., Riedinger, N., Slomp, C., Snowball, I., Stepanova, A., Strano, S., Torti, A., Warnock, J., Xiao, N., and Zhang, R., 2015b. Site M0062. In Andrén, T., Jørgensen, B.B., Cotterill, C., Green, S., and the Expedition 347 Scientists, Proc. IODP, 347: College Station, TX (Integrated Ocean Drilling Program). doi:10.2204/ iodp.proc.347.106.2015

Frenzel, P., Keyser, D., and Viehberg, F.A., 2010. An illustrated key and (palaeo)ecological primer for postglacial to Recent Ostracoda (Crustacea) of the Baltic Sea. Boreas, 39(3):567-575. doi:10.1111/j.1502-3885.2009.00135.X

Hajdu, S., Larsson, U., and Skärlund, K., 1997. Växtplankton. In Elmgren, R., and Larsson, U. (Eds.), Himmerfjärden: förändringar i ett näringsbelastat kustekosystem iÖstersjön (Rapport 4565): Stockholm (Naturvårdsverketförlag), 63-79. (in Swedish, with abstract in English)

Hasle, G.R., and Syvertsen, E.E., 1990. Arctic diatoms in the Oslofjord and the Baltic Sea-a bio- and palaeogeographic problem. In Simmola, H. (Ed.), Proceedings of the 10th International Diatom Symposium: Koenigstein, Germany (Koeltz Scientific Books), 285-300.

Hedenström, A., and Risberg, J., 1999. Early Holocene shore-displacement in southern central Sweden as recorded in elevated isolated basins. Boreas, 28(4):490504. doi:10.1111/j.1502-3885.1999.tb00236.x

Huntley, B., and Birks, H.J.B., 1983. An Atlas of Past and Present Pollen Maps for Europe: 0-13,000 Years Ago: Cambridge, U.K. (Cambridge Univ. Press).

Lutze, G.F., 1965. Zur foraminiferen-fauna der ostsee (The distribution of foraminifera in the Baltic Sea). Meyniana, 15:75-142.

Mertens, K.N., Ribeiro, S., Bouimetarhan, I., Caner, H., Nebout, N.C., Dale, B., De Vernal, A., Ellegaard, M., Filipova, M., Godhe, A., Goubert, E., Grøsfjeld, K., Holz- 
warth, U., Kotthoff, U., Leroy, S.A.G., Londeix, L., Marret, F., Matsuoka, K., Mudie, P.J., Naudts, L., PeñaManjarrez, J.L., Persson, A., Popescu, S.-M., Pospelova, V., Sangiorgi, F., van der Meer, M.T.J., Vink, A., Zonneveld, K.A.F., Vercauteren, D., Vlassenbroeck, J., and Louwye, S., 2009. Process length variation in cysts of a dinoflagellate, Lingulodinium machaerophorum, in surface sediments: investigating its potential as salinity proxy. Mar. Micropaleontol., 70(1-2):54-69. doi:10.1016/ j.marmicro.2008.10.004

Nehring, S., 1994. Dinoflagellaten-Dauercysten in deutschen Küstengewässern: Vorkommen, Verbreitung und Bedeutung als Rekrutierungspotential. Ber. Inst. Meereskd. ChristianAlbrechts-Univ., Kiel, 259.

Rottgardt, D., 1952. Mikropaläontologische wichtige Bestandteile rezenter brakischer Sedimente an den Küsten Schleswig-Holsteins. Meyniana 1:169-228.

Roussel, E.G., Cambon Bonavita, M.-A., Querellou, J., Cragg, B.A., Webster, G., Prieur, D., and Parkes, J.R., 2008. Extending the sub-sea-floor biosphere. Science, 320(5879):1046. doi:10.1126/science.1154545

Samuelsson, M., 1996. Interannual salinity variations in the Baltic Sea during the period 1954-1990. Cont. Shelf Res., 16(11):1463-1477. doi:10.1016/02784343(95)00082-8

Segerström, U., and von Stedingk, H., 2003. Early Holocene spruce, Picea abies (L.) Karst., in west central Swe- den as revealed by pollen analysis. Holocene, 13(6):897906. doi:10.1191/0959683603hl672rp

Snoeijs, P., Vilbaste, S., Potapova, M., Kasperoviciene, J., and Balashova, J. (Eds.), 1993-1998. Intercalibration and Distribution of Diatom Species in the Baltic Sea (Vol. 1-5): Uppsala, Sweden (Opulus Press).

Snowball, I., Zillén, L., Ojala, A., Saarinen, T., and Sandgren, P., 2007. FENNOSTACK and FENNORPIS: varve dated Holocene palaeomagnetic secular variation and relative palaeointensity stacks for Fennoscandia. Earth Planet. Sc. Lett., 255(1-2):106-116. doi:10.1016/ j.epsl.2006.12.009

Snowball, I.F., 1997. Gyroremanent magnetization and the magnetic properties of greigite-bearing clays in southern Sweden. Geophys. J. Int., 129(3):624-636. doi:10.1111/j.1365-246X.1997.tb04498.X

Weckström, K., and Juggins, S., 2006. Coastal diatom-environment relationships from the Gulf of Finland, Baltic Sea. J. Phycol., 42(1):21-35. doi:10.1111/j.15298817.2006.00166.x

Widerlund, A., and Andersson, P.S., 2011. Late Holocene freshening of the Baltic Sea derived from high-resolution strontium isotope analyses of mollusk shells. Geology, 39(2):187-190. doi:10.1130/G31524.1

Publication: 20 February 2015 MS 347-105 
Figure F1. Graphic lithology log summary, Hole M0061A and base of Hole M0061B.

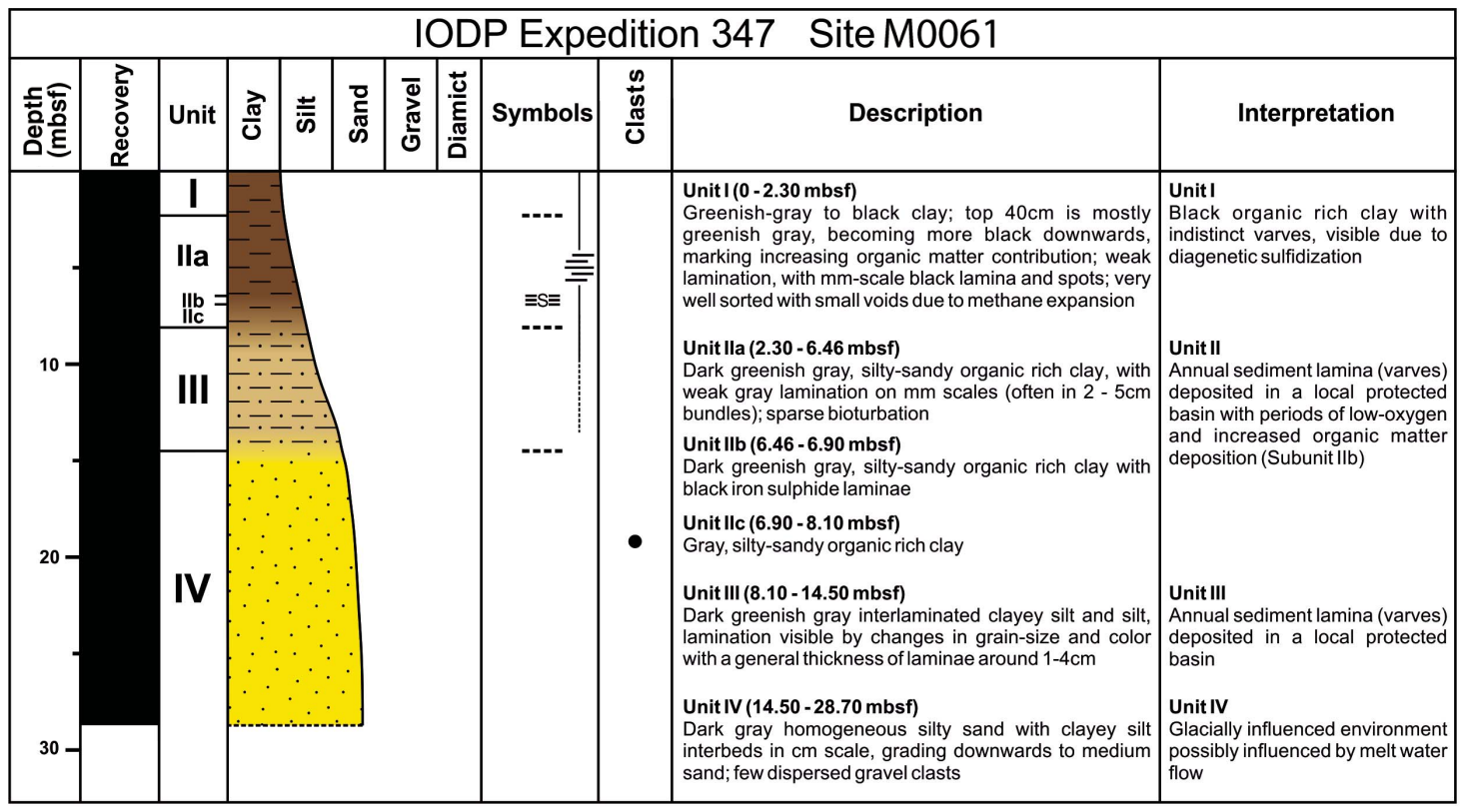


Figure F2. Black laminated horizon (Subunit IIa) that represents increased iron sulfide diagenetic processes (interval 347-M0061A-3H-2, 2-69 cm).

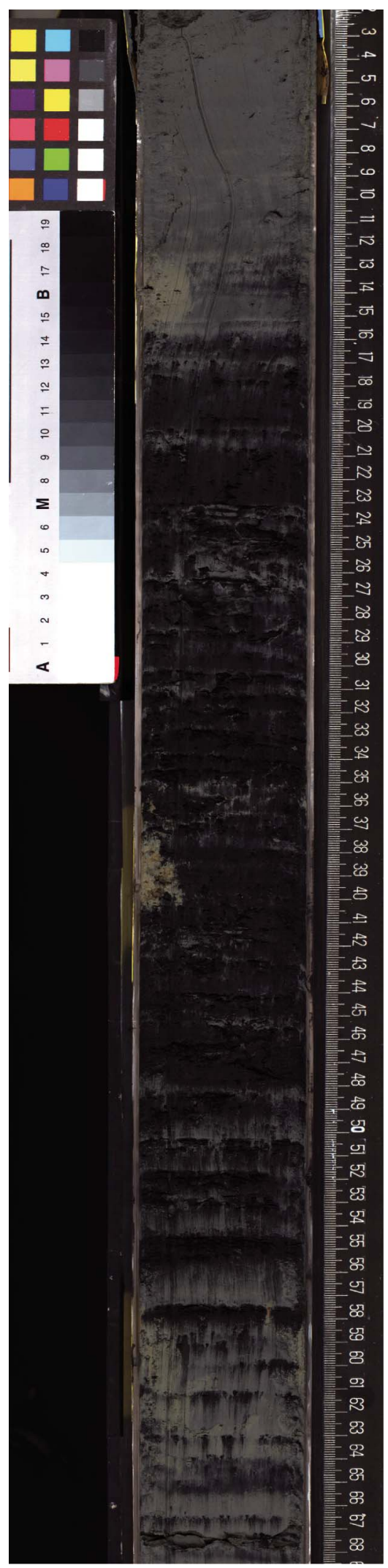


Figure F3. Analyzed levels of siliceous microfossils and the proportion of diatom taxa showing different salinity affinities, Site M0061. The total number of diatom taxa recorded is plotted, as well as the number of taxa associated with planktonic, periphytic, and sea ice related taxa. Red dots indicate presence of sea ice related taxa and other siliceous microfossils recorded in the cores. This graph must be interpreted with caution because it is based only on qualitative analyses. Each species was counted only present or absent, so a species represented by a single valve carries as much weight as a species dominating the assemblage.

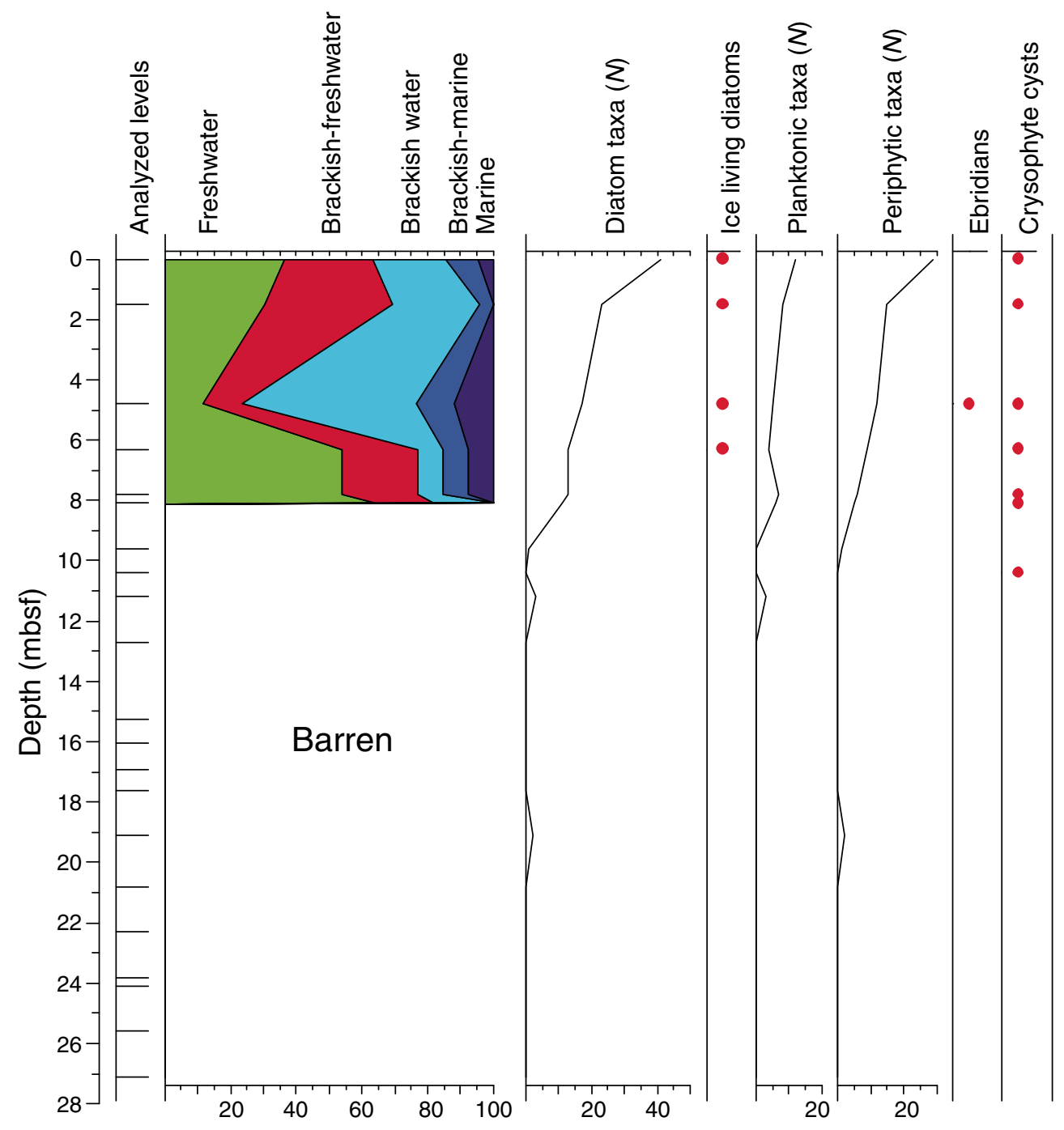


Figure F4. Analyzed levels of siliceous microfossils and the proportion of diatom taxa showing different salinity affinities, Hole M0061B. The total number of diatom taxa recorded is plotted, as well as the number of taxa associated to planktonic, periphytic, and sea ice related taxa. Red dots indicate presence of sea ice related taxa and other siliceous microfossils recorded in the cores. This graph must be interpreted with caution because it is based only on qualitative analyses. Each species was counted only present or absent, so a species represented by a single valve carries as much weight as a species dominating the assemblage.

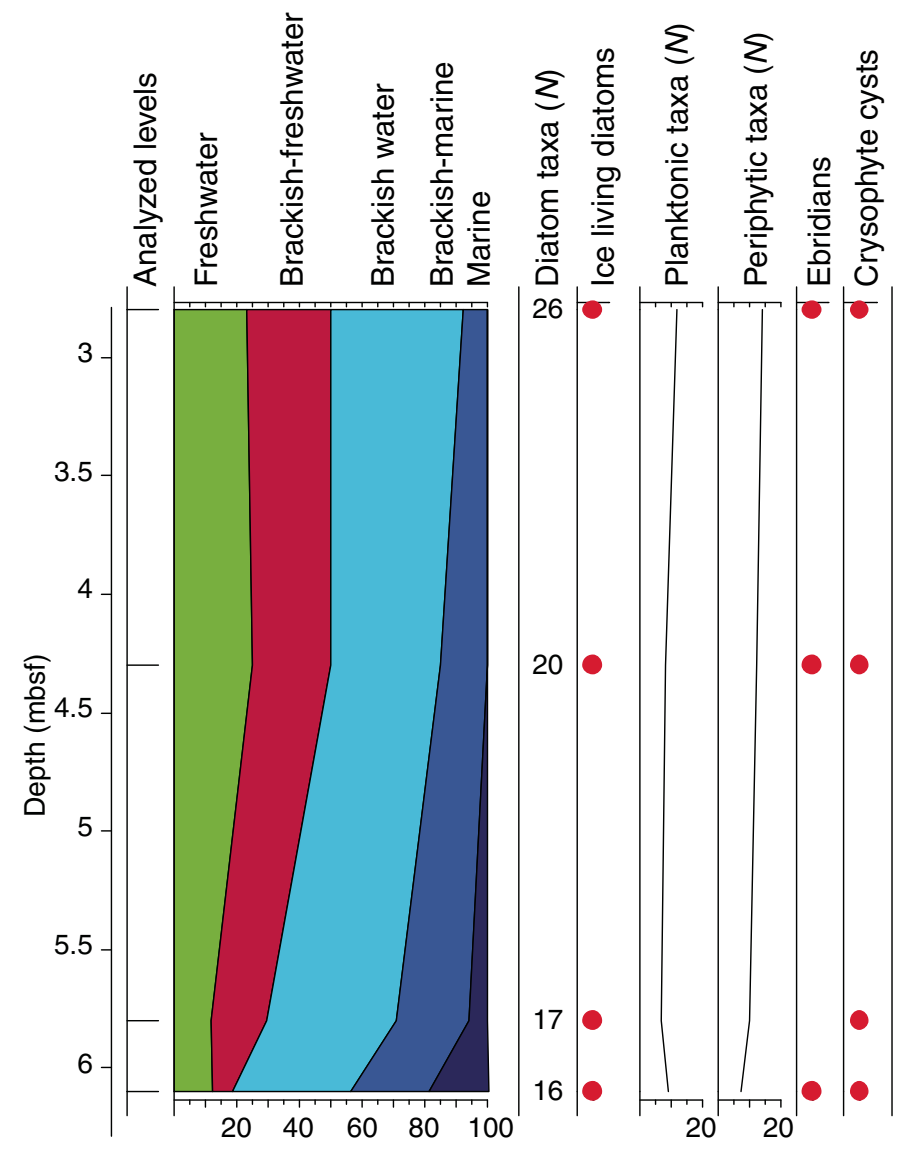


Figure F5. Abundance of benthic foraminifers based on the abundance classification defined in the "Methods" chapter (Andrén et al., 2015a), Site M0061. A running average over three samples is plotted onto single data points. Increasing shading indicates abundances sufficient for faunal and/or geochemical analyses.

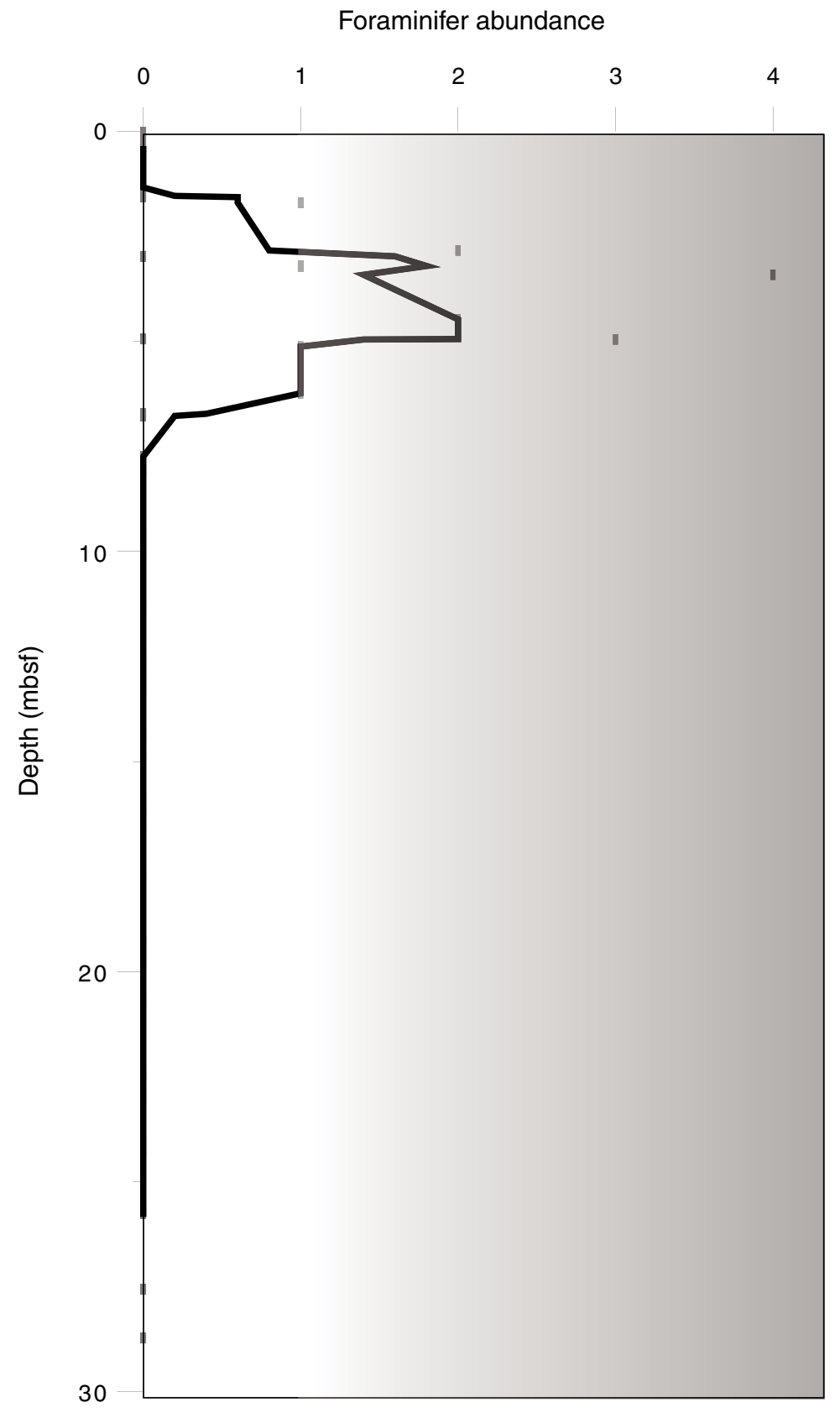


Figure F6. Ostracod abundance, Site M0061. Abundance is shown per sediment volume.

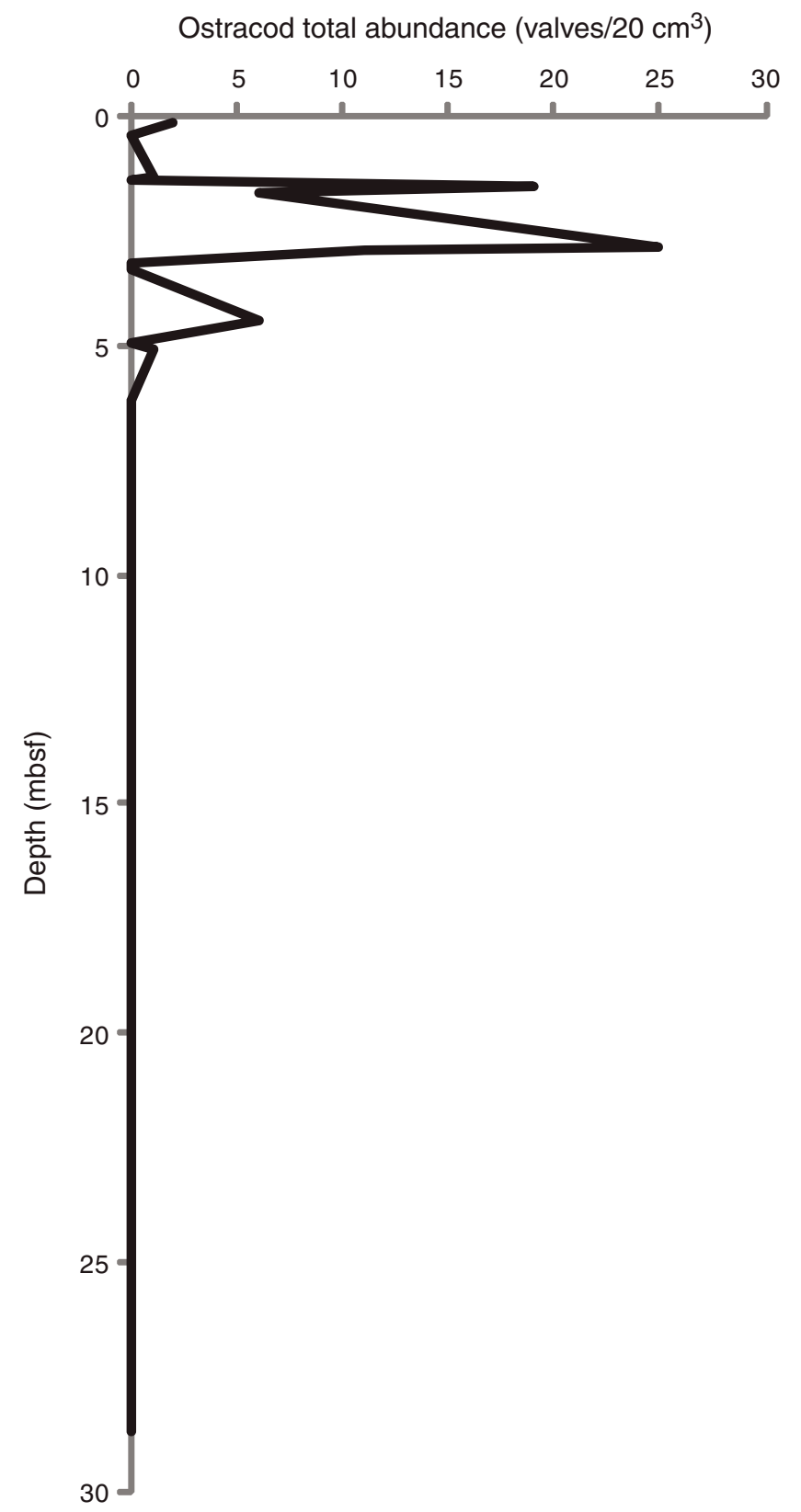


Figure F7. Pollen diagram with bisaccate pollen included in the reference sum, Hole M0061B. For all samples, between 150 and 310 grains have been counted.

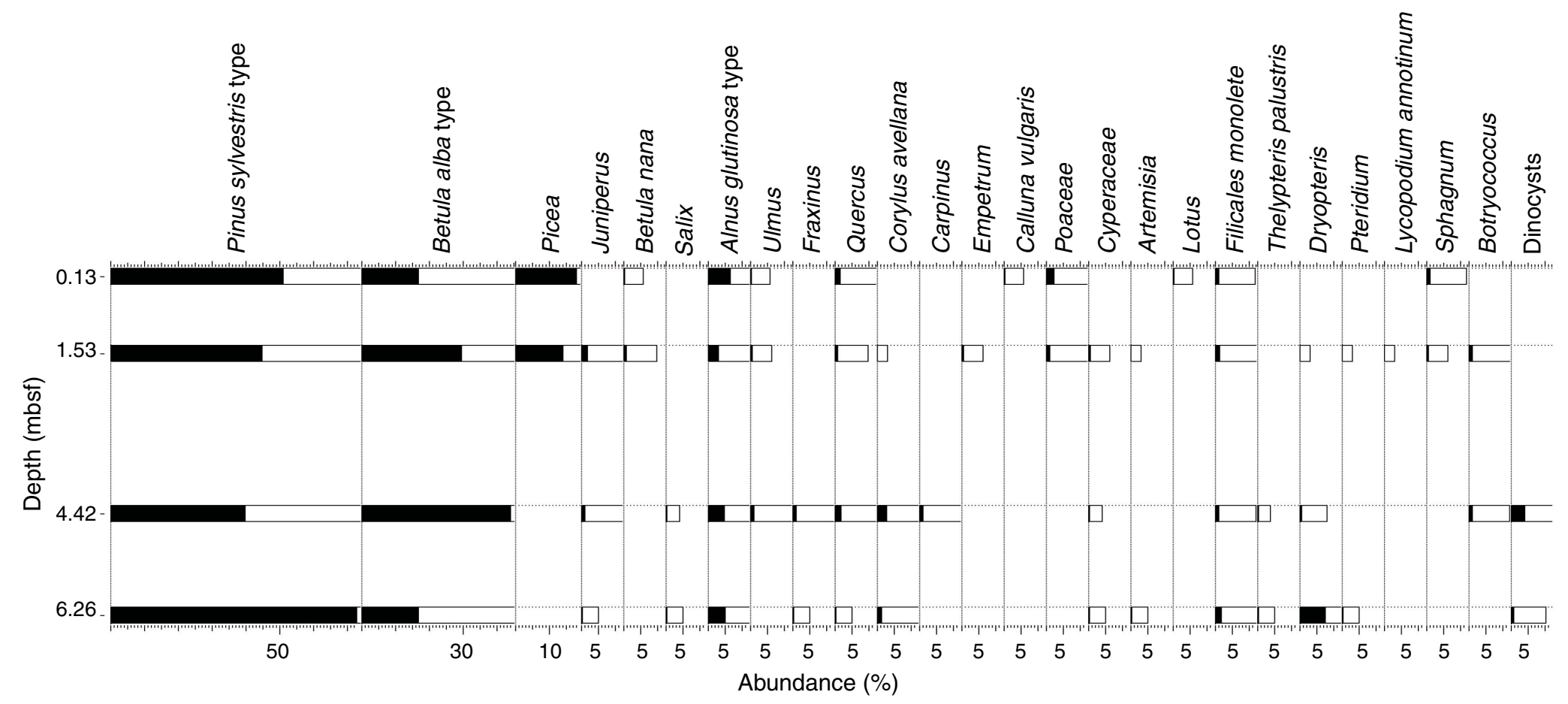


Figure F8. Simplified pollen diagram with main pollen types, further palynomorph data, and occurrences of Radiosperma corbiferum, Hole M0061B.

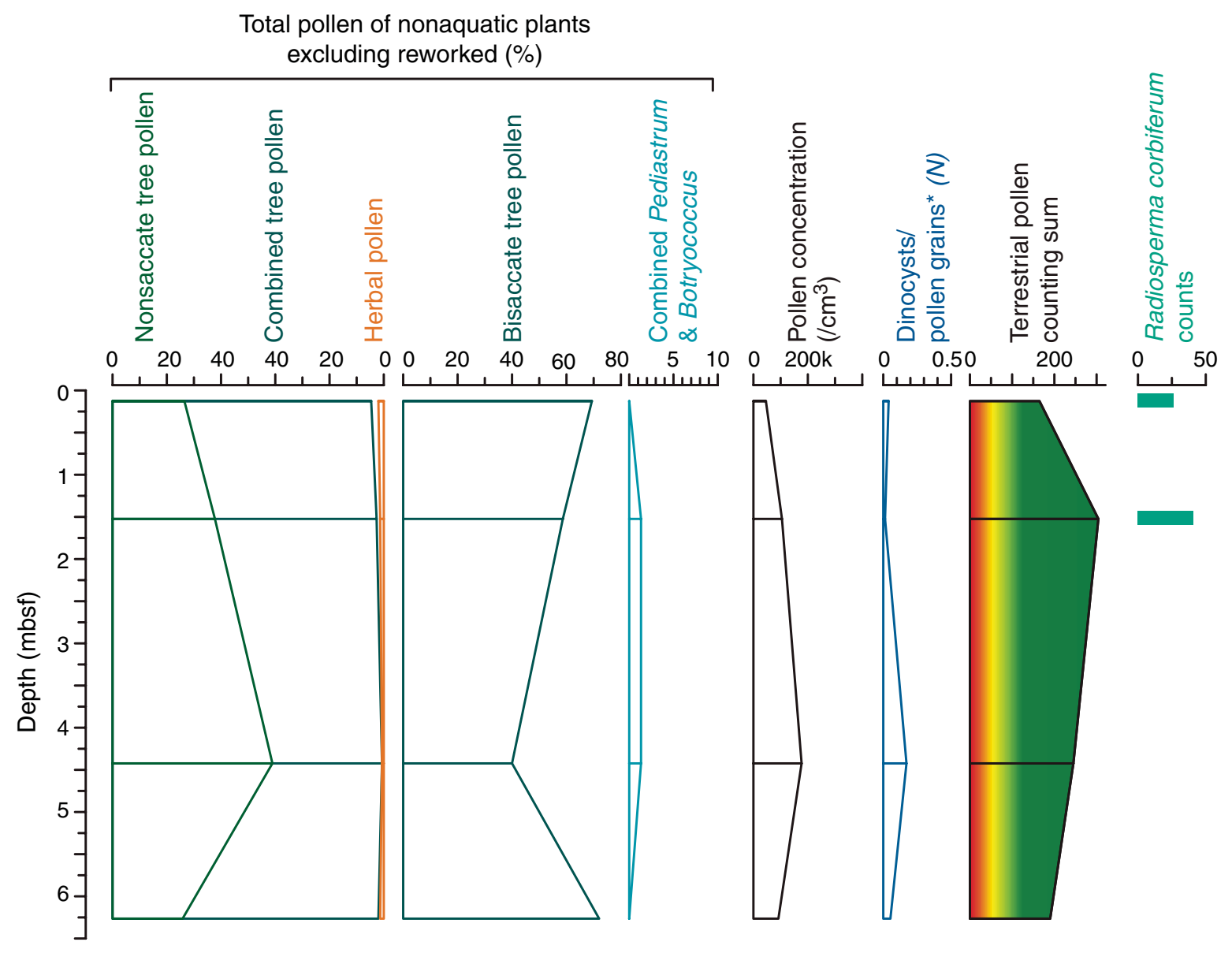


Figure F9. Concentrations of (A) chloride, (B) salinity, (C) chloride-based salinity by refractometer, and (D) alkalinity in interstitial water samples, Site M0061.
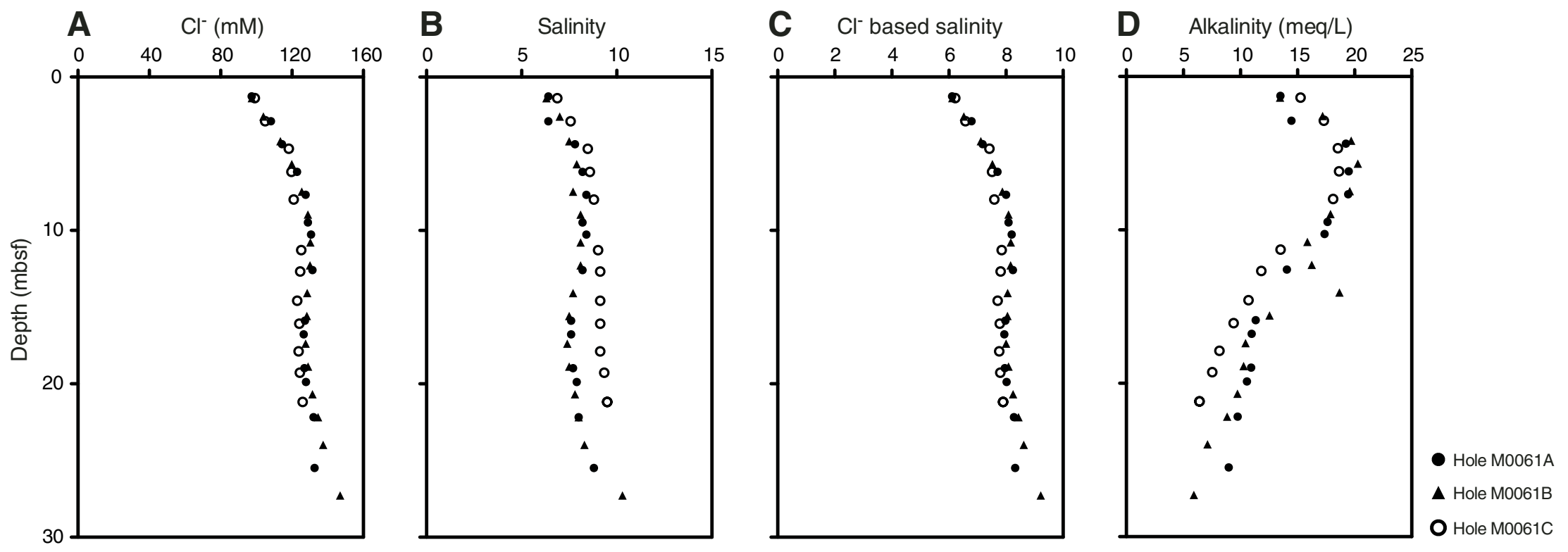
Figure F10. Concentrations of (A) sulfate, (B) sulfide, (C) ammonium, (D) phosphate, (E) iron, (F) manganese, and (G) pH from interstitial water samples, Site M0061.
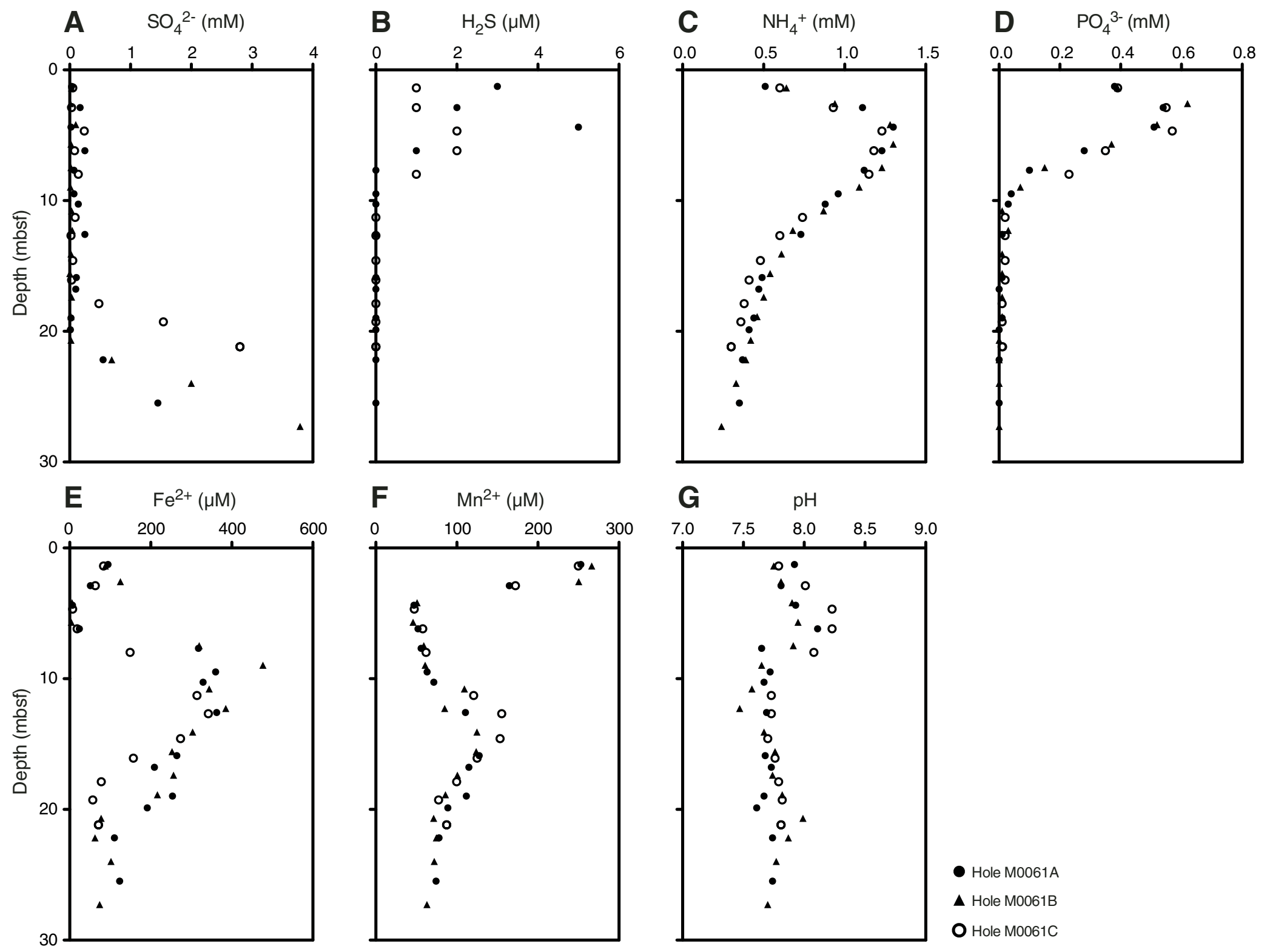
Figure F11. Concentrations and ratios of (A) bromide, (B) bromide/chloride, (C) boron, and (D) boron/chloride from interstitial water samples, Site M0061. Dashed lines = seawater ratio.
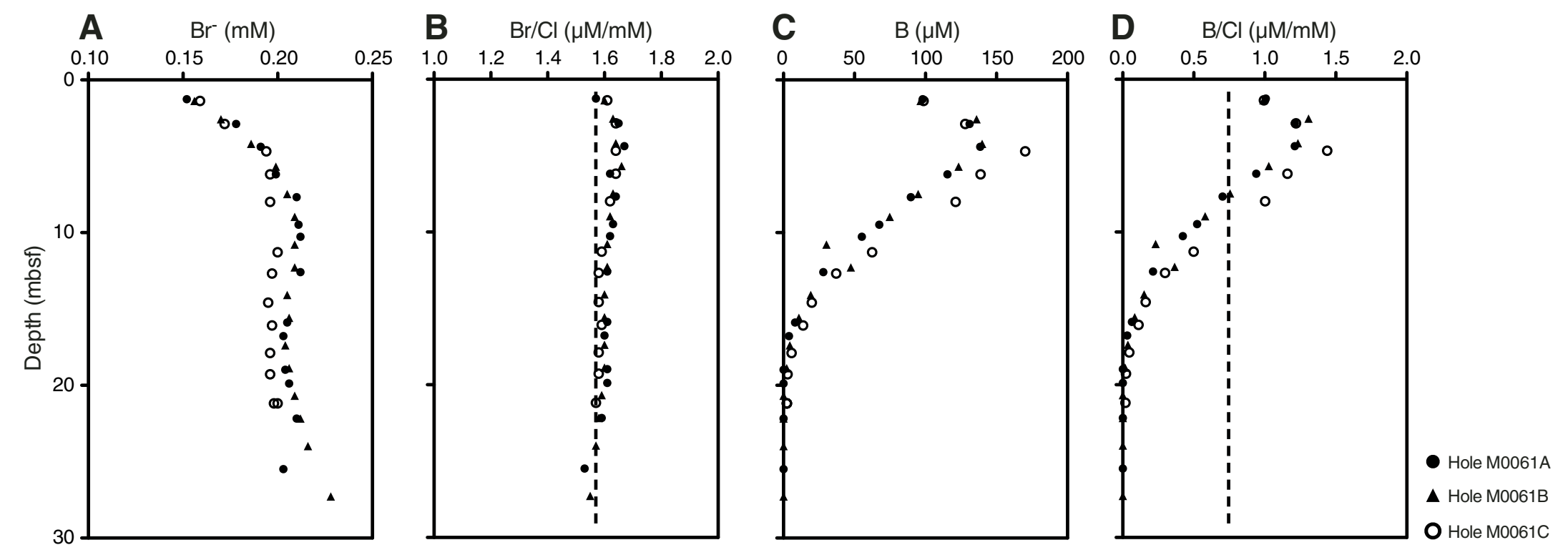
Figure F12. Concentrations and ratios of (A) sodium, (B) potassium, (C) magnesium, (D) calcium, (E) sodium/chloride, (F) potassium/chloride, (G) magnesium/chloride, and (H) calcium/chloride in interstitial water samples, Site M0061. Dashed lines = seawater ratio.
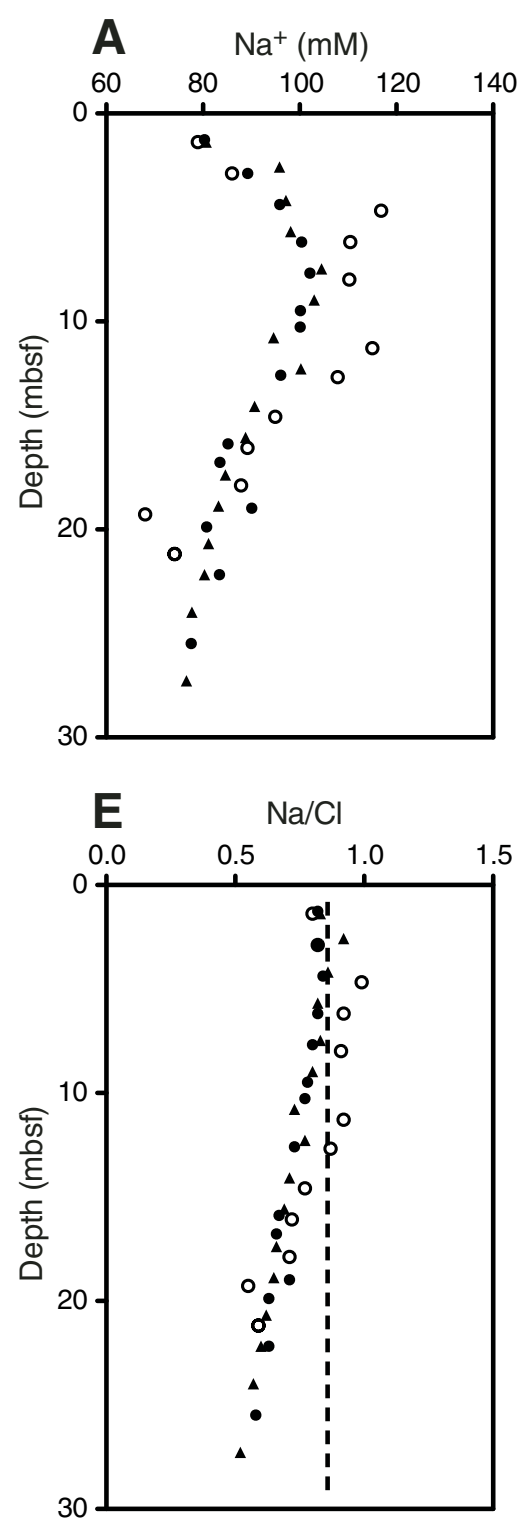
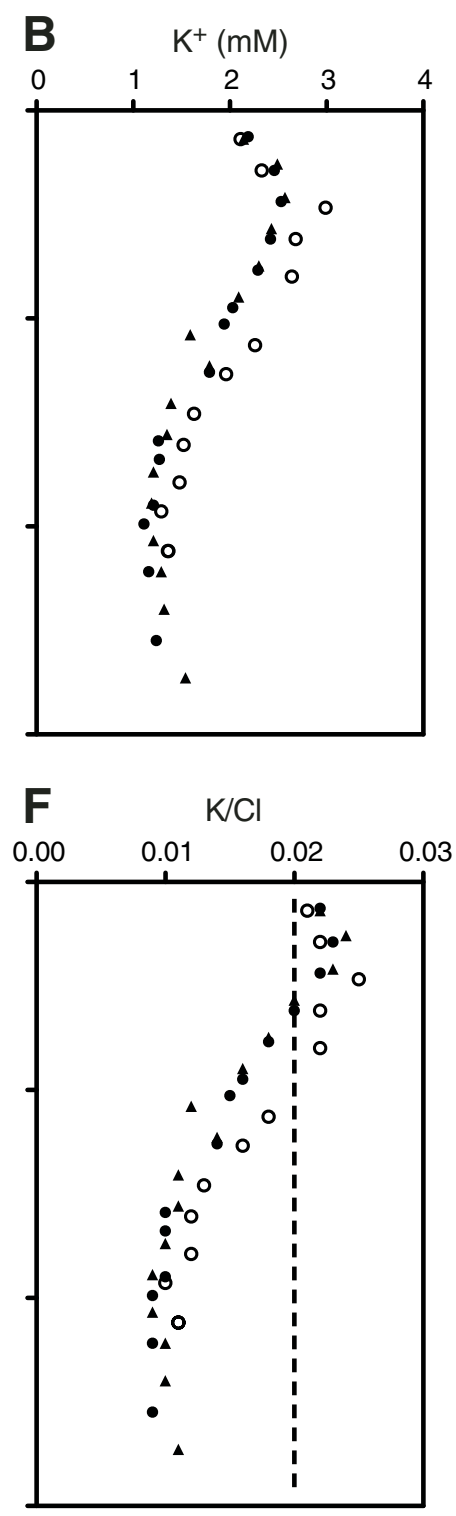
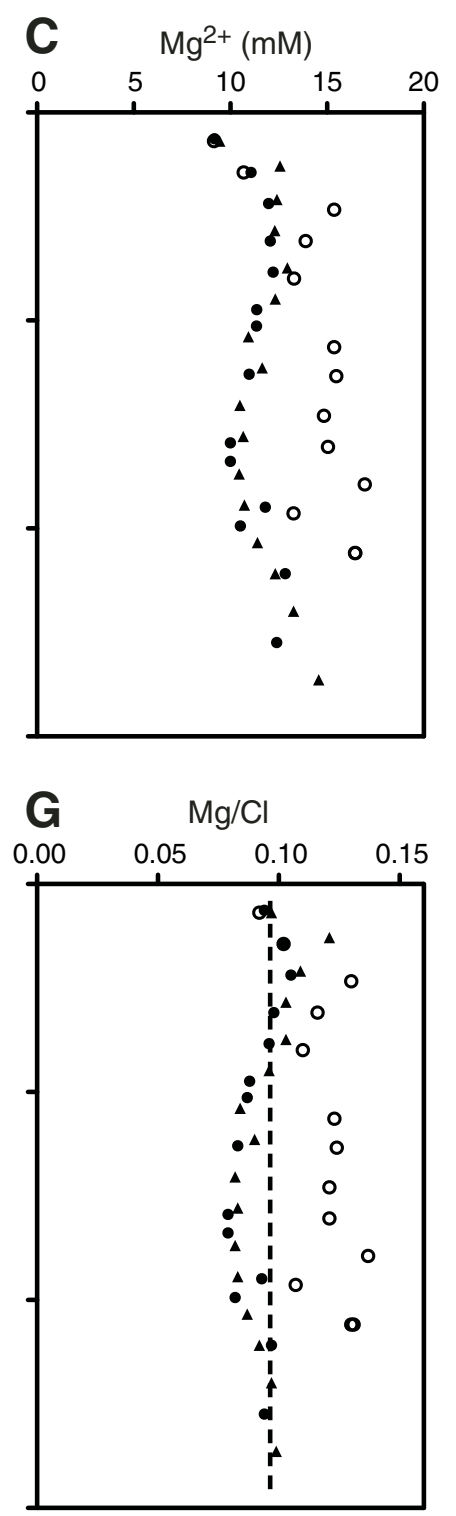

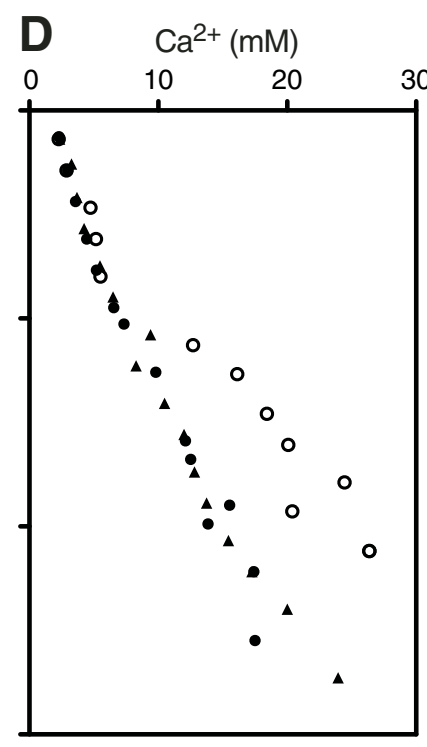

H

$\begin{array}{llllll}0.00 & 0.05 & 0.10 & 0.15 & 0.20 & 0.25\end{array}$

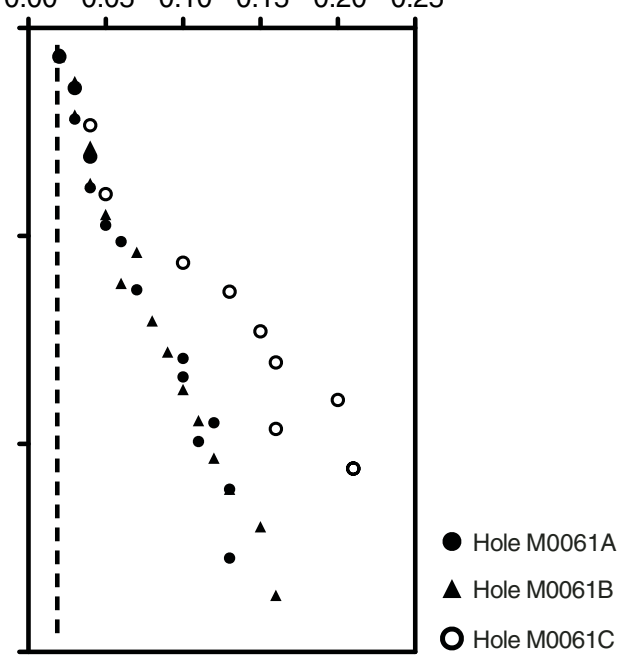



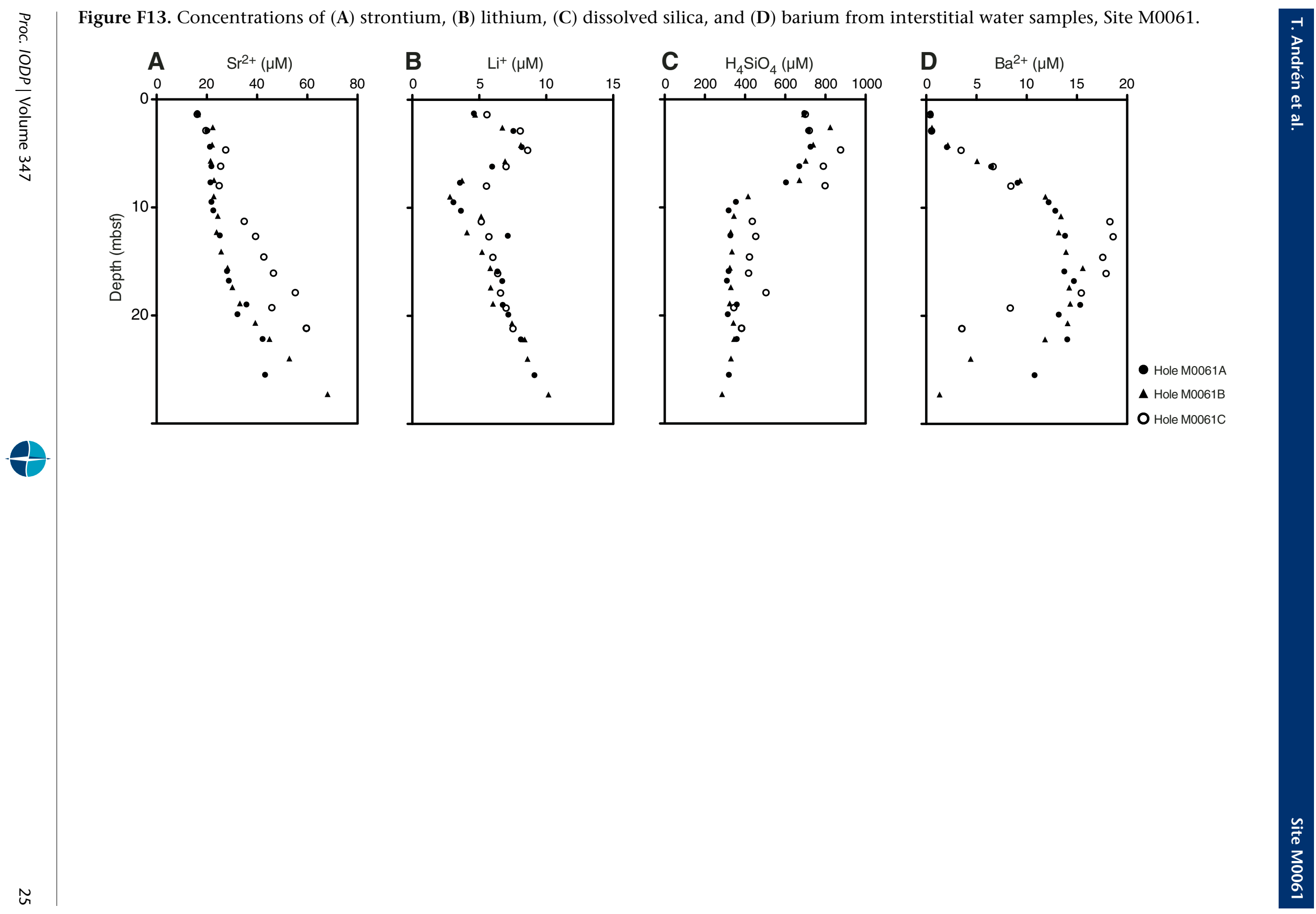
Figure F14. Solid phase concentrations of (A) total carbon (TC), (B) total organic carbon (TOC), (C) total inorganic carbon (TIC), and (D) total sulfur (TS), Site M0061.
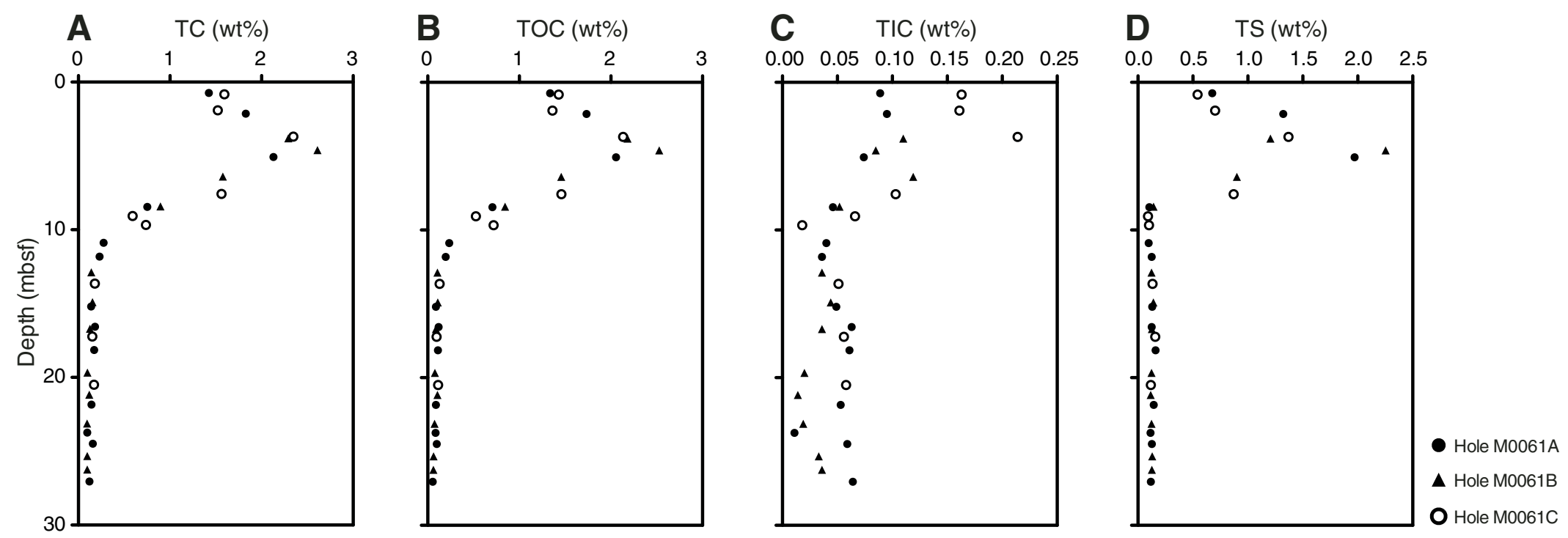
Figure F15. Magnetic susceptibility (MS) $\left(10^{-5} \mathrm{SI}\right)$, natural gamma radiation (NGR) (cps), noncontact resistivity $(\mathrm{NCR})(\Omega \mathrm{m}), P$-wave velocity $(\mathrm{m} / \mathrm{s})$, and $\mathrm{b}^{*}$, Hole M0061B.

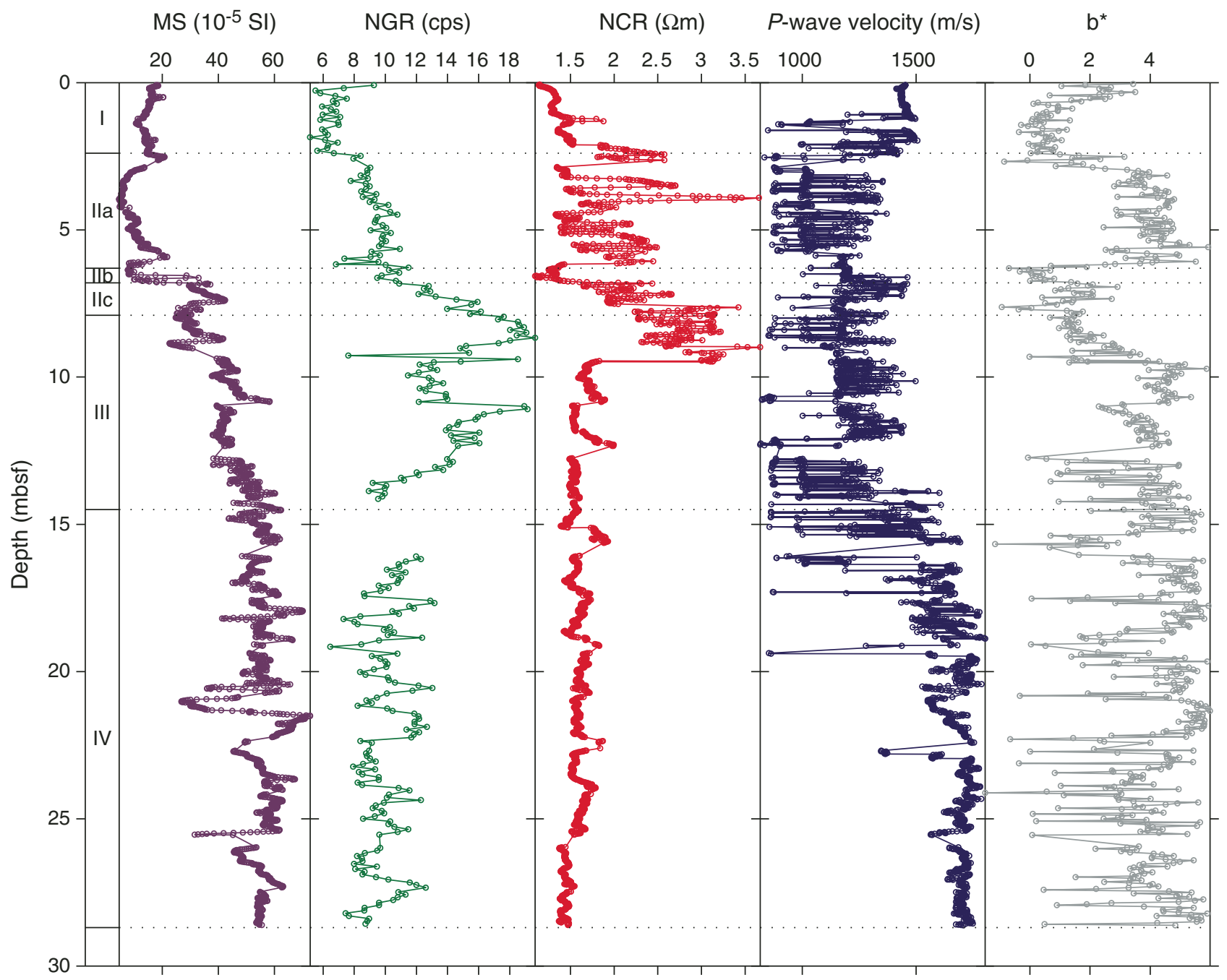


Figure F16. Gamma density $\left(\mathrm{g} / \mathrm{cm}^{3}\right)$ and discrete bulk density $\left(\mathrm{g} / \mathrm{cm}^{3}\right)$ measurements derived from pycnometer moisture and density analyses, Hole M0061B.

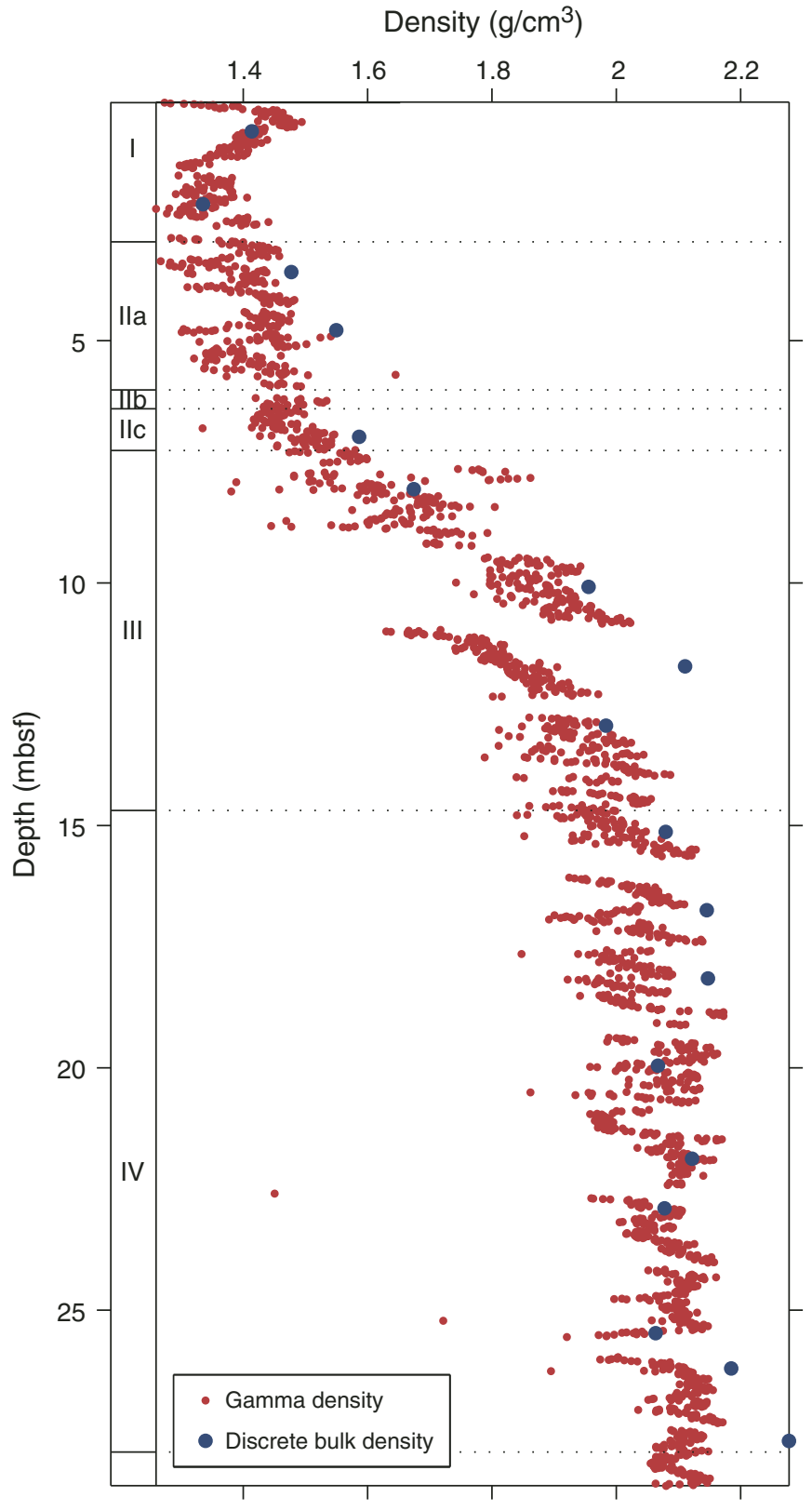


Figure F17. Gamma density $\left(\mathrm{g} / \mathrm{cm}^{3}\right)$ and discrete bulk density $\left(\mathrm{g} / \mathrm{cm}^{3}\right)$ measurements are highly correlated in Hole M0061B.

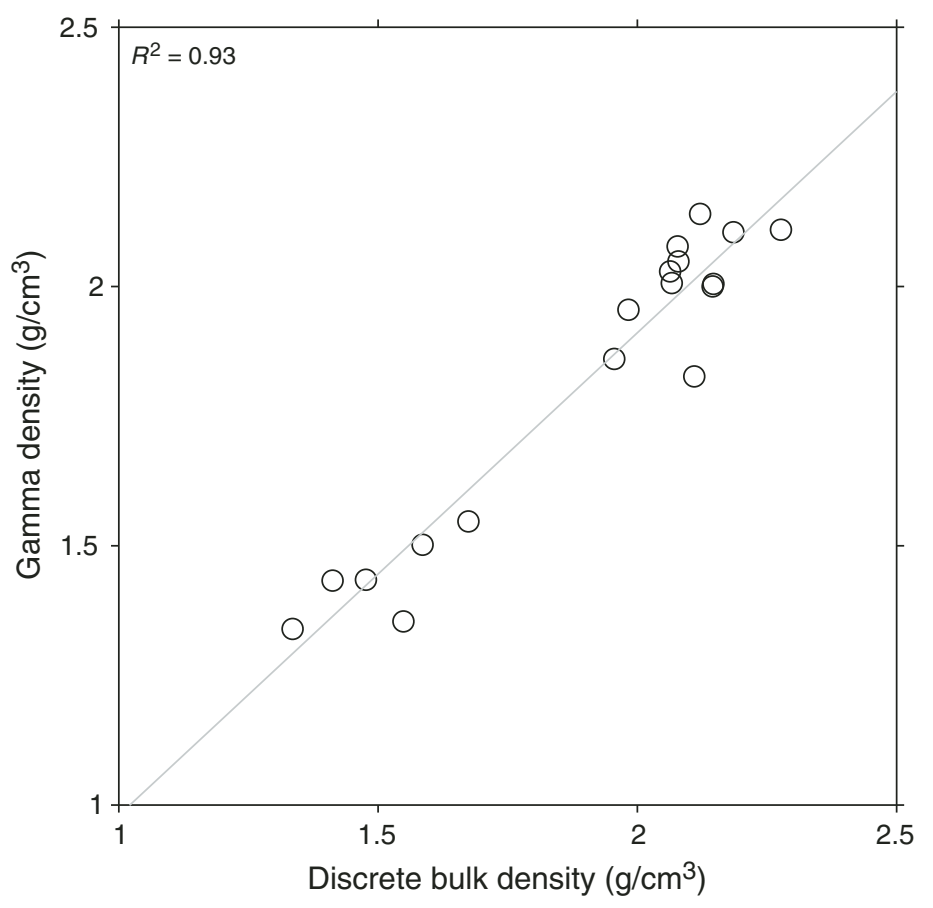


Figure F18. Plots and biplots of magnetic susceptibility $(\chi)$, natural remanent magnetization (NRM) intensity, and NRM inclination of discrete paleomagnetic samples, Hole M0061A. Dashed line = geocentric axial dipole $(\mathrm{GAD})$ prediction of inclination for the site latitude $\mathrm{AF}=\mathrm{alternating}$ field.
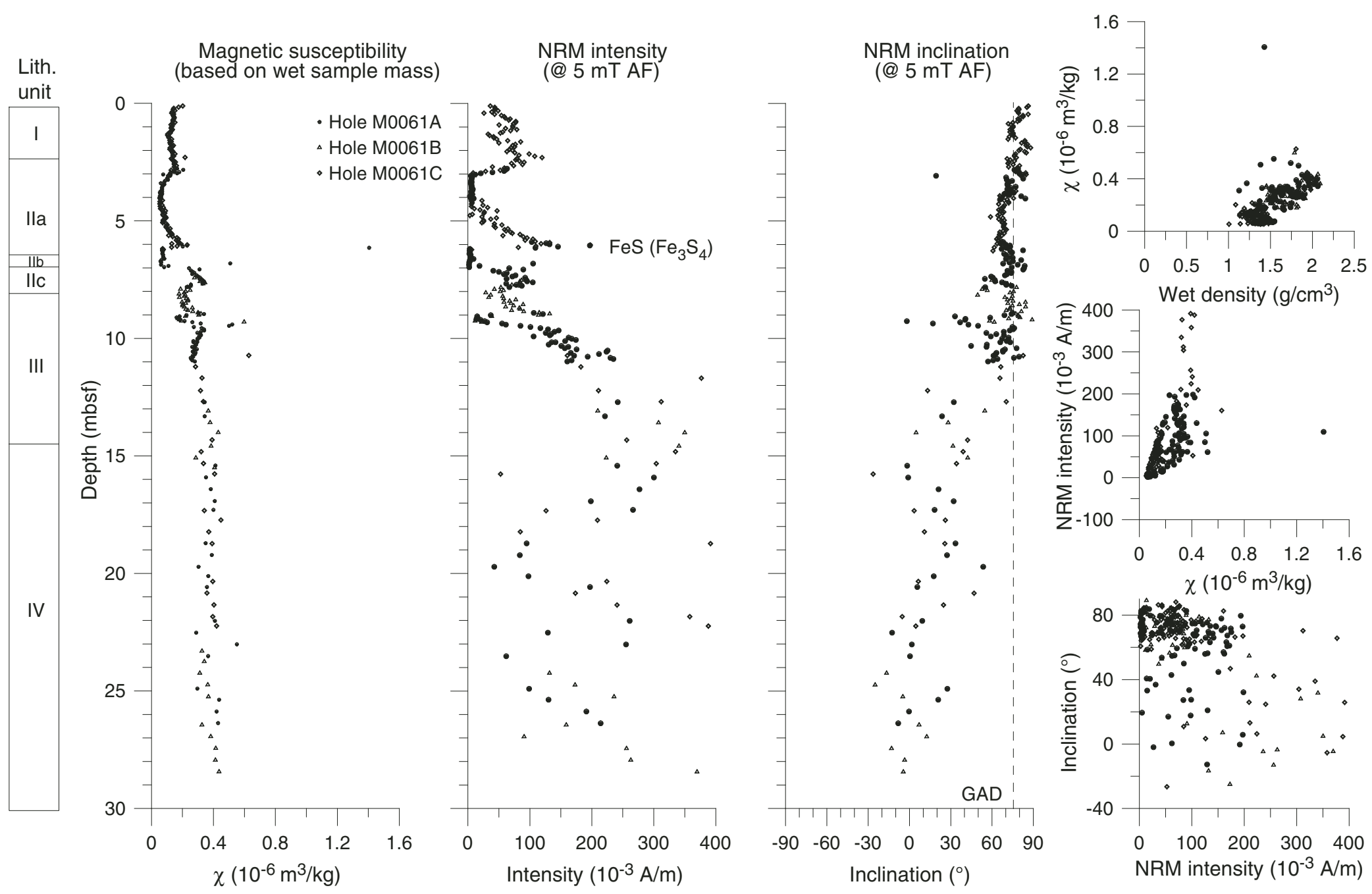
Figure F19. Plots of natural remanent magnetization after alternating field (AF) demagnetization to $80 \mathrm{mT}$. A. Sample 347-M0061A-3H-1, 89 cm; 5.89 mcd. B. Sample 347-M0061A-4H-1, 138 cm; 9.81 mcd. C. Sample 347-M0061A-9H-2, $120 \mathrm{~cm} ; 22.01 \mathrm{mcd}$. Category 2 and 3 vectors trend toward the origin and display high magnetic stability, whereas Category 1 vectors contain a low-stability component. The vector veers into a plane perpendicular to the last demagnetization axis, which is a sign of gyroremanent magnetization acquisition. Open squares $=$ vertical, solid squares $=$ horizontal.
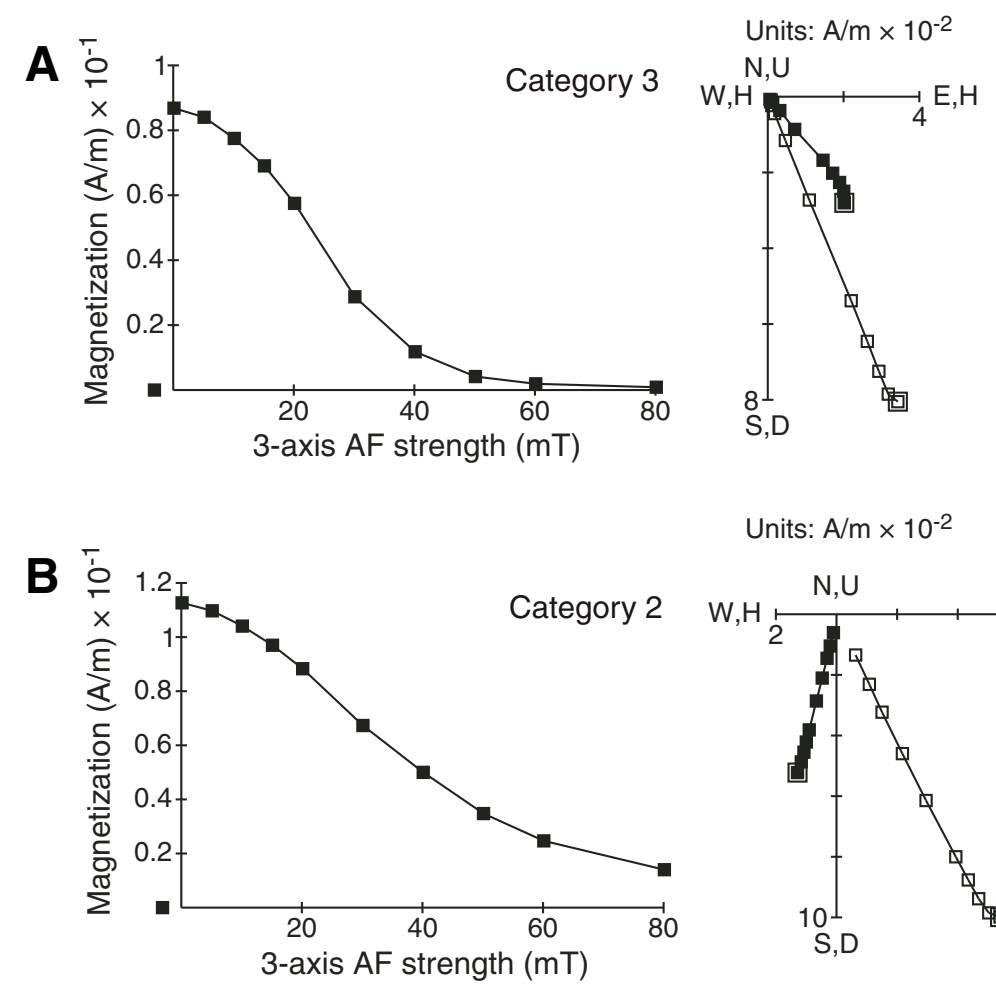

$$
\text { Units: } A / m \times 10^{-2}
$$
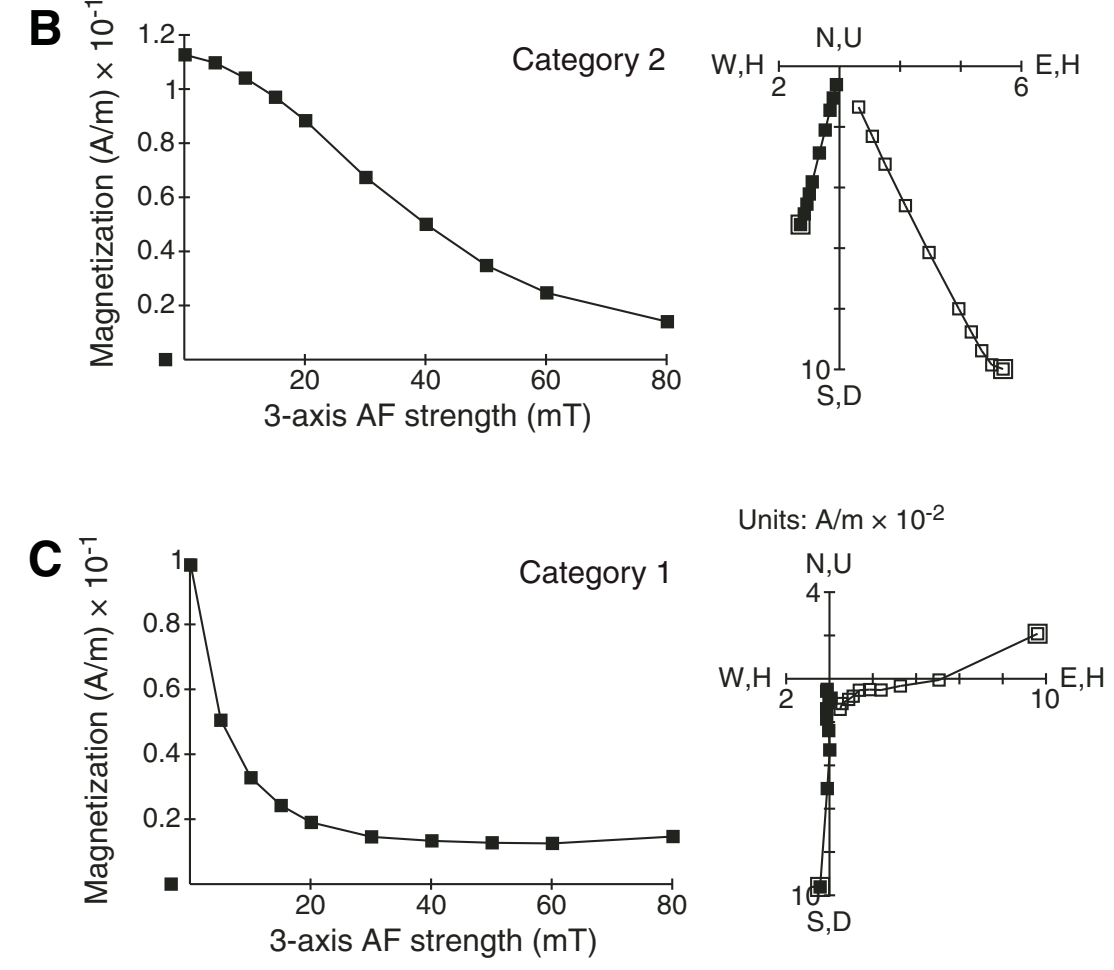
Figure F20. Plot of microbial cell abundance (red diamonds), Hole M0061K. Solid black line = global regression line of prokaryote cell numbers with depth, dashed lines = upper and lower 95\% prediction limits for regression line (Roussel et al., 2008).

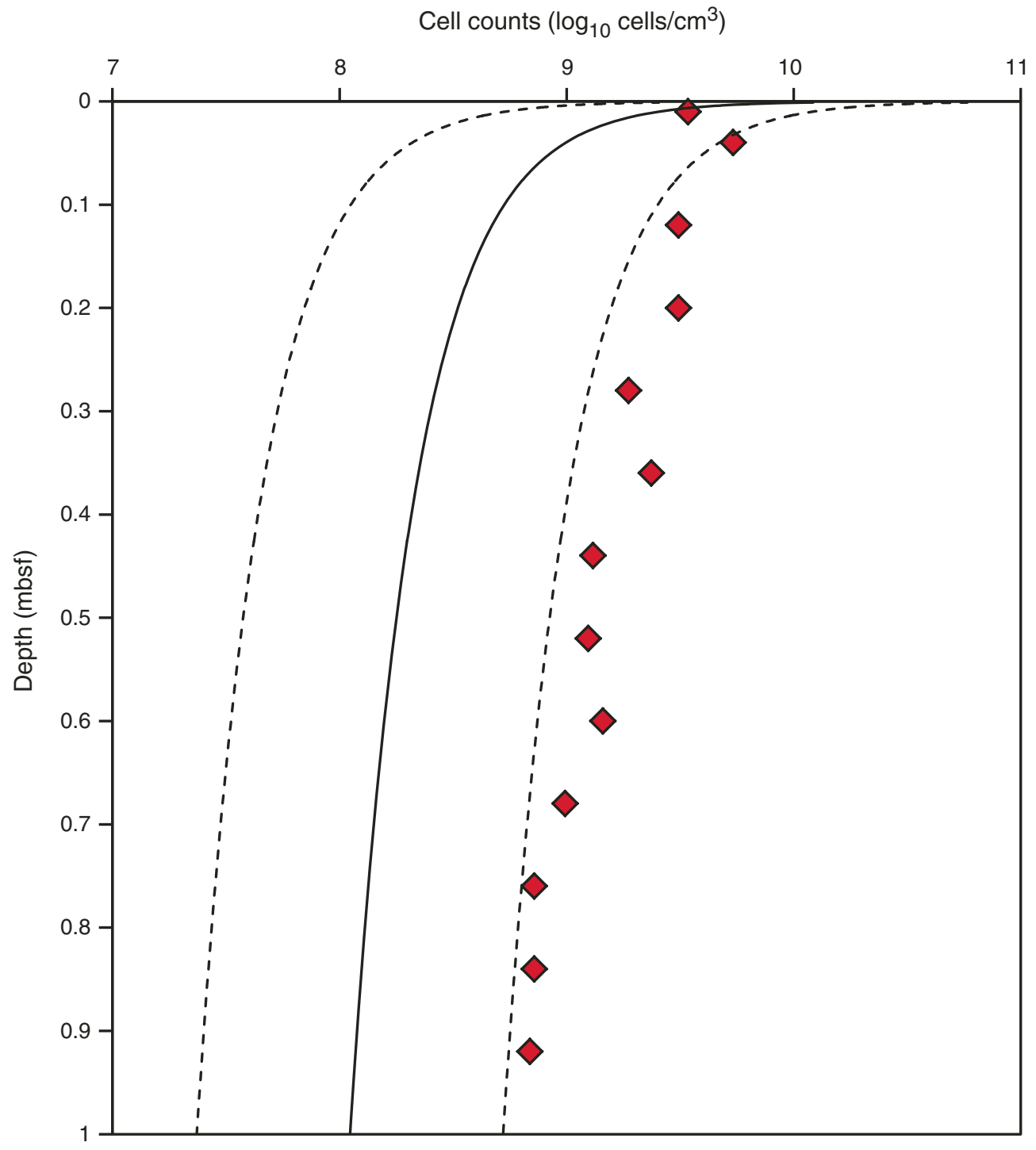


Figure F21. Plot of spliced magnetic susceptibility data, Holes M0061A-M0061C. Letters and numbers at the top refer to holes and core runs, respectively, used in the splice.

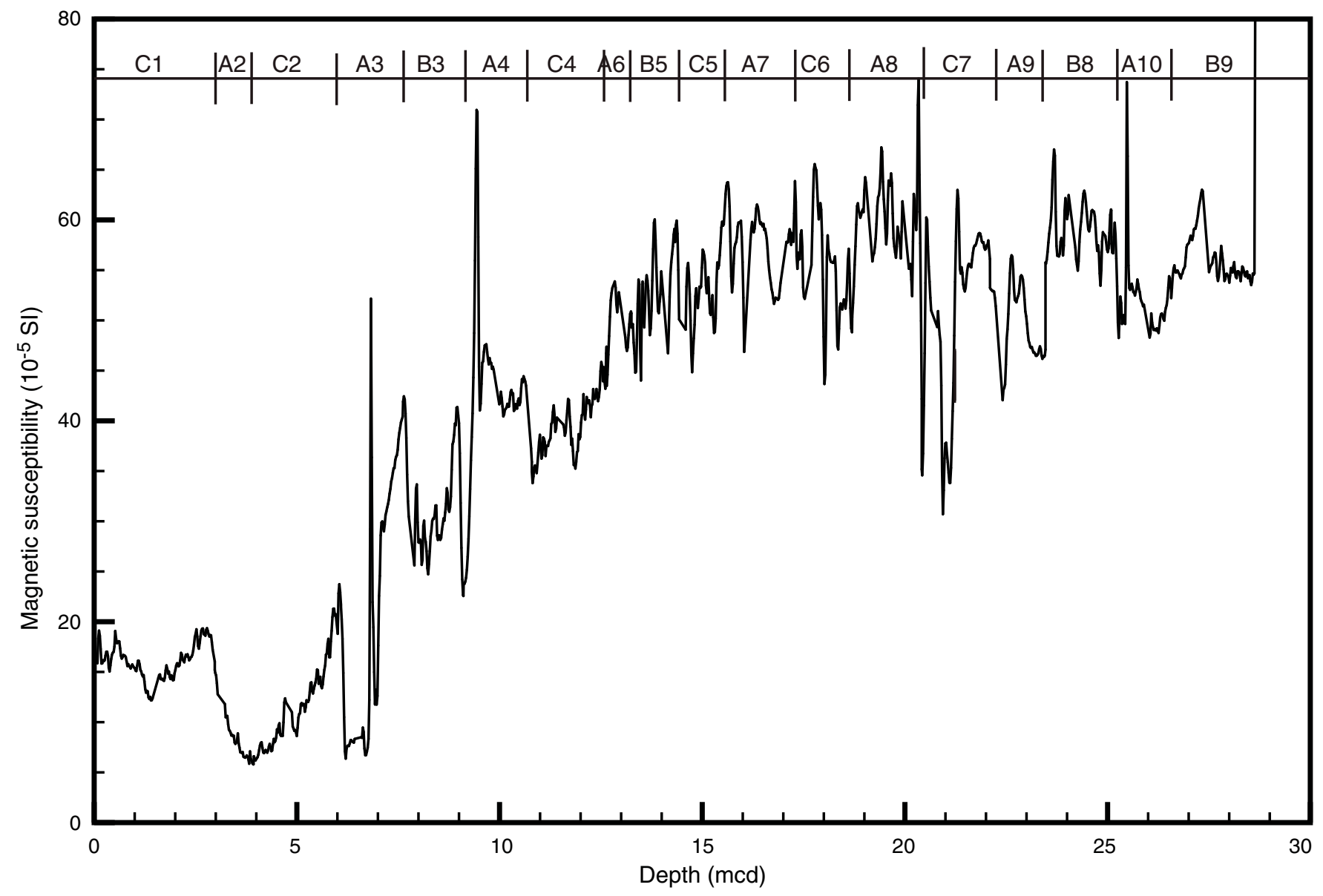


Figure F22. Correlation of the seismic profile with lithostratigraphic units (I-IV) and multisensor core logger magnetic susceptibility data (Hole M0061A), Site M0061.

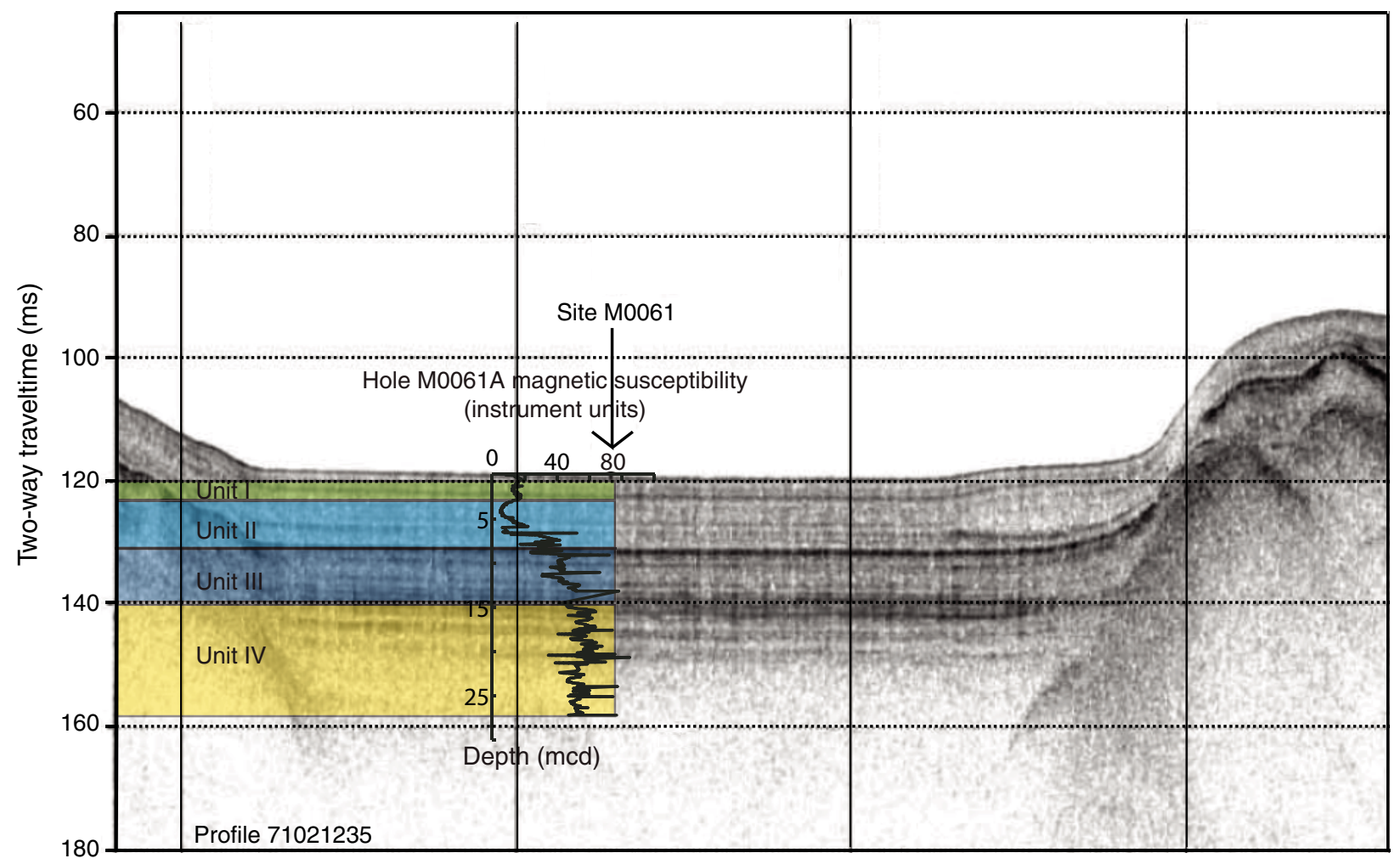


Table T1. Operations, Site M0061.

\begin{tabular}{|c|c|c|c|c|c|c|c|c|c|}
\hline \multirow[b]{2}{*}{ Core } & \multirow{2}{*}{$\begin{array}{l}\text { Coring } \\
\text { method }\end{array}$} & \multirow{2}{*}{$\begin{array}{l}\text { Date } \\
(2013)\end{array}$} & \multirow{2}{*}{$\begin{array}{l}\text { Time } \\
\text { (UTC) }\end{array}$} & \multicolumn{2}{|c|}{ Depth (mbsf) } & \multirow{2}{*}{$\begin{array}{l}\text { Recovered } \\
(\mathrm{m})\end{array}$} & \multirow{2}{*}{$\begin{array}{l}\text { Recovery } \\
(\%)\end{array}$} & \multirow[b]{2}{*}{ Mud type } & \multirow[b]{2}{*}{ Comments } \\
\hline & & & & Top & Bottom & & & & \\
\hline \multicolumn{10}{|c|}{ 347-M0061A- } \\
\hline & & 4 Oct & 1230 & & & & & & $\begin{array}{l}\text { Seabed template not lowered, piston fired in water at } 0.5 \mathrm{~m} \text { above the estimated mudline to capture } \\
\text { sediment/water interface; on recovery, water depth reassessed and string lowered to calculated mudline }\end{array}$ \\
\hline $1 \mathrm{H}$ & PCS & 4 Oct & 1335 & 0.00 & 1.50 & 1.53 & 102 & Seawater & Drilled out $3.3 \mathrm{~m}$ from last sample, added pipe, and lowered seabed template to seabed \\
\hline $2 \mathrm{H}$ & PCS & 4 Oct & 1355 & 1.50 & 4.80 & 3.44 & 104.24 & Seawater & 65 bar; good fire sequence, good recovery \\
\hline $3 \mathrm{H}$ & PCS & 4 Oct & 1520 & 4.80 & 8.10 & 3.28 & 99.39 & Seawater & \\
\hline $4 \mathrm{H}$ & PCS & 4 Oct & 1555 & 8.10 & 11.20 & 3.18 & 102.58 & Seawater & Barrel stuck; eventually freed after hammering with overshot and pumping water \\
\hline $5 \mathrm{H}$ & PCS & 4 Oct & 1630 & 11.20 & 11.20 & 0.00 & 0 & Seawater & Stopped to fix deck lights, which failed to come back on following a ship power failure \\
\hline $6 \mathrm{H}$ & PCS & 4 Oct & 1718 & 11.20 & 14.50 & 2.13 & 64.55 & Seawater & Piston fired at 60 bar \\
\hline $7 \mathrm{H}$ & PCS & 4 Oct & 1834 & 14.50 & 17.60 & 3.18 & 102.58 & Seawater & $\begin{array}{l}\text { Pressurized up to } 220 \text { bar without any apparent firing point; on release of pressure and recovery of the corer, } \\
\text { we had collected } 3.3 \mathrm{~m} \text { of very fine to fine sand }\end{array}$ \\
\hline $8 \mathrm{H}$ & PCS & 4 Oct & 1935 & 17.60 & 20.80 & 3.17 & 99.06 & Seawater & $\begin{array}{l}\text { Prepared drill floor to lift template; lifted template and positioned large transponder; returned template to } \\
\text { seabed and replaced mouseholes }\end{array}$ \\
\hline $9 \mathrm{H}$ & PCS & 4 Oct & 2030 & 20.80 & 24.10 & 3.30 & 100 & Guar & Washed down to $24.1 \mathrm{mbsf}$ and ran PCS \\
\hline $10 \mathrm{H}$ & PCS & 4 Oct & 2054 & 24.10 & 25.10 & 3.15 & 315 & Guar & Pressure reached $135 \mathrm{bar}$; sample probably sucked in \\
\hline \multirow[t]{2}{*}{$11 \mathrm{~S}$} & HS & 4 Oct & 2220 & 25.10 & 25.20 & 0.10 & 100 & Guar & $\begin{array}{l}\text { Hammer sample when no progress made while washing down from } 24.1 \text { mbsf; recovered rock-looks like } \\
\text { bedrock rather than clast or pebble }\end{array}$ \\
\hline & & 4 Oct & 2300 & & & & & & Pulled string \\
\hline \multicolumn{10}{|c|}{ 347-M0061B- } \\
\hline & & 4 Oct & 2340 & & & & & & Started lowering drill string \\
\hline $1 \mathrm{H}$ & PCS & 5 Oct & 0000 & 0.00 & 2.80 & 2.83 & 101.07 & Seawater & Fired piston from $\sim 0.5 \mathrm{~m}$ above seabed \\
\hline $2 \mathrm{H}$ & PCS & 5 Oct & 0025 & 2.80 & 6.10 & 3.43 & 103.94 & Seawater & \\
\hline $3 \mathrm{H}$ & PCS & 5 Oct & 0113 & 6.10 & 9.40 & 3.44 & 104.24 & Seawater & $10 \mathrm{bar}$ then zero \\
\hline $4 \mathrm{H}$ & PCS & 5 Oct & 0143 & 9.40 & 12.70 & 3.15 & 95.45 & Seawater & $\begin{array}{l}\text { Not a clean fire; } 50 \text { bar, dropped then went up to } 125 \text { bar before dropping away quickly; bottom of core run } \\
\text { was more silty if not sandy; changed to Guar mud while drilling down }\end{array}$ \\
\hline $5 \mathrm{H}$ & PCS & 5 Oct & 0211 & 12.70 & 16.00 & 3.17 & 96.06 & Guar & $\begin{array}{l}50 \mathrm{bar} \text {, then up to } 80 \mathrm{bar} \text {, then rising to } 100 \mathrm{bar} \text { before dropping and then rising to } 125 \mathrm{bar} \text { and dropping all } \\
\text { the way; possible sand/silt layers; still very soft at the bottom }\end{array}$ \\
\hline $6 \mathrm{H}$ & PCS & 5 Oct & 0245 & 16.00 & 19.30 & 3.30 & 100 & Guar & Same firing pattern as before but less pressure after firing \\
\hline 7H & PCS & 5 Oct & 0320 & 19.30 & 22.60 & 3.21 & 97.27 & Guar & $50 \mathrm{bar}$, then up to 80 then 100 then 130 bar before dropping to zero; still sand indications \\
\hline \multirow[t]{2}{*}{$8 \mathrm{H}$} & PCS & 5 Oct & 0450 & 22.60 & 25.90 & 3.09 & 93.64 & Guar & Fired as normal but pressure did not drop fully and then went up over 125 bar until the pipe was lifted \\
\hline & & 5 Oct & 0506 & & & & & & $\begin{array}{l}\text { Tool stuck in the hole, hammer overshot but no release; ran overshot release and tried to free by pumping; } \\
\text { recovered on the second attempt }\end{array}$ \\
\hline \multirow[t]{3}{*}{$9 \mathrm{H}$} & PCS & 5 Oct & 0545 & 25.90 & 28.70 & 2.83 & 101.07 & Guar & $\begin{array}{l}\text { Fired: other than slight pressure flicker, firing point was not discernible and continued upward, stopped by the } \\
\text { driller at } 125 \text { bar; did not release pressure until rooster box was lifted; pumped before attempting recovery }\end{array}$ \\
\hline & & 5 Oct & 0604 & & & & & & $\begin{array}{l}\text { Unable to release corer despite hammering; released overshot to allow more pumping; eventually successful in } \\
\text { recovering corer after pumping and hammering with the overshot }\end{array}$ \\
\hline & & 5 Oct & 0645 & & & & & & Tripped pipe to allow bump over for Hole M0061B \\
\hline \multicolumn{10}{|c|}{ 347-M0061C- } \\
\hline & & 5 Oct & 0700 & & & & & & \\
\hline $1 \mathrm{H}$ & PCS & 5 Oct & 0725 & 0.00 & 3.30 & 3.41 & 103.33 & Seawater & $50 \mathrm{bar}$, right down to zero \\
\hline $2 \mathrm{H}$ & PCS & 5 Oct & 0805 & 3.30 & 6.60 & 3.42 & 103.64 & Seawater & Fired normally \\
\hline $3 \mathrm{H}$ & PCS & 5 Oct & 0850 & 6.60 & 9.90 & 3.44 & 104.24 & Seawater & Fired normally \\
\hline $4 \mathrm{H}$ & PCS & 5 Oct & 0915 & 9.90 & 13.20 & 3.14 & 95.15 & Seawater & Fired, pressure up then down to zero \\
\hline $5 \mathrm{H}$ & PCS & 5 Oct & 1035 & 13.20 & 16.50 & 3.37 & 102.12 & Seawater & $50 \mathrm{bar}$, down to zero \\
\hline $6 \mathrm{H}$ & PCS & 5 Oct & 1110 & 16.50 & 19.80 & 3.22 & 97.58 & Seawater & $60 \mathrm{bar}$, down to zero \\
\hline \multirow[t]{3}{*}{$7 \mathrm{H}$} & PCS & 5 Oct & 1145 & 19.80 & 23.10 & 3.17 & 96.06 & Seawater & $110 \mathrm{bar}$, had to release pressure at pump \\
\hline & & 5 Oct & 1220 & & & & & & Tripped pipe \\
\hline & & & & & & & & & Completed and awaiting pilot for transit to Site M0062 \\
\hline
\end{tabular}


Table T2. Diatoms, Hole M0061A. (Continued on next page.)

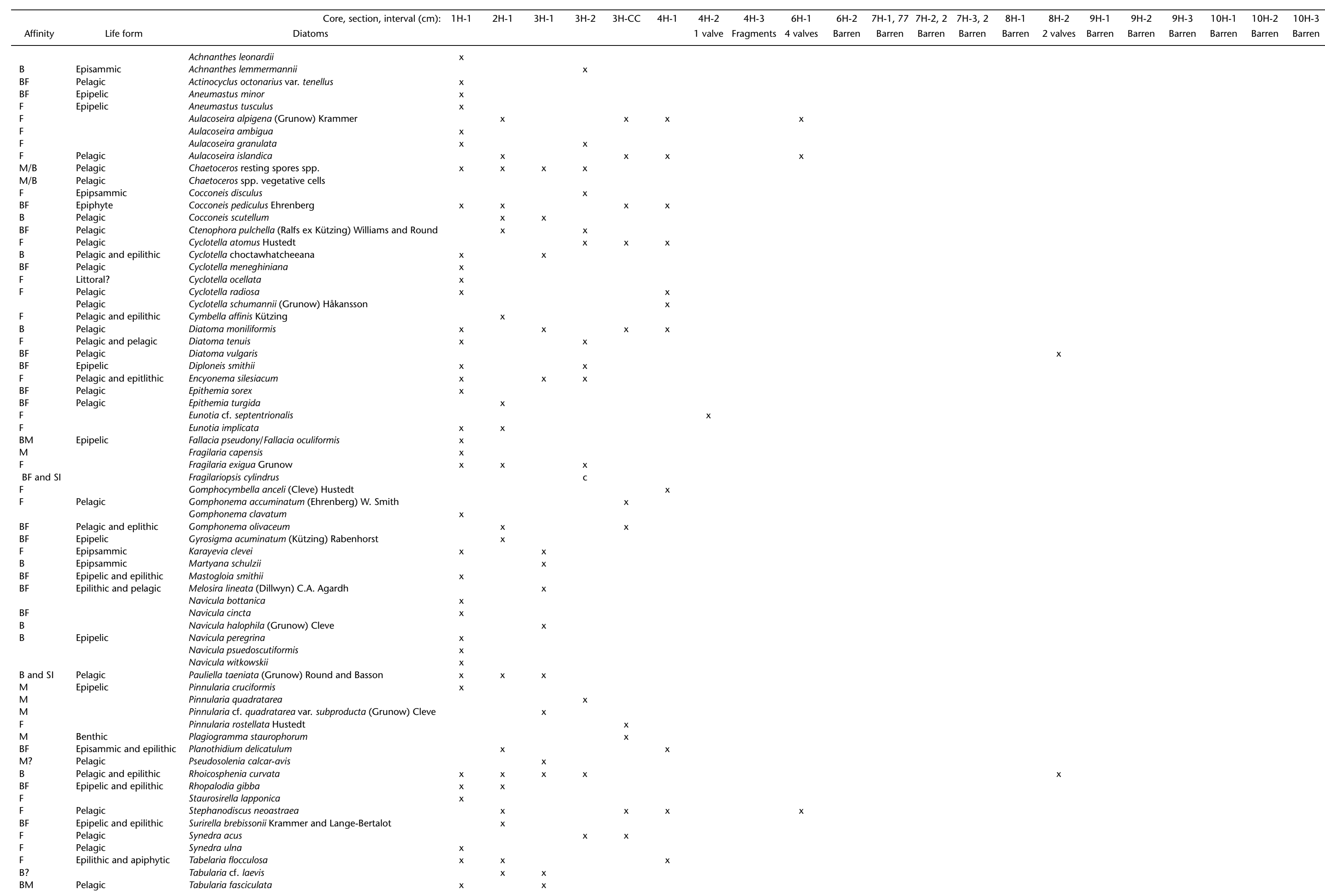


Table T2 (continued)

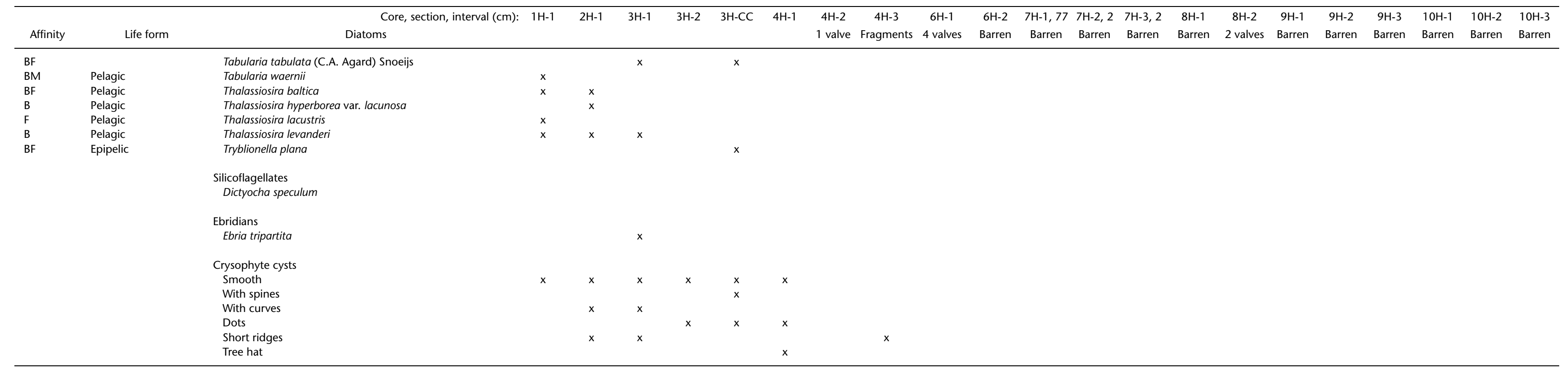

$\mathrm{F}=$ freshwater, $\mathrm{BF}=$ brackish-freshwater, $\mathrm{B}=$ brackish, $\mathrm{BM}=$ brackish-marine, $\mathrm{M}=$ marine. $\mathrm{x}=$ present, $\mathrm{C}=$ common. ? = uncertain. 
Table T3. Diatoms, Hole M0061B.

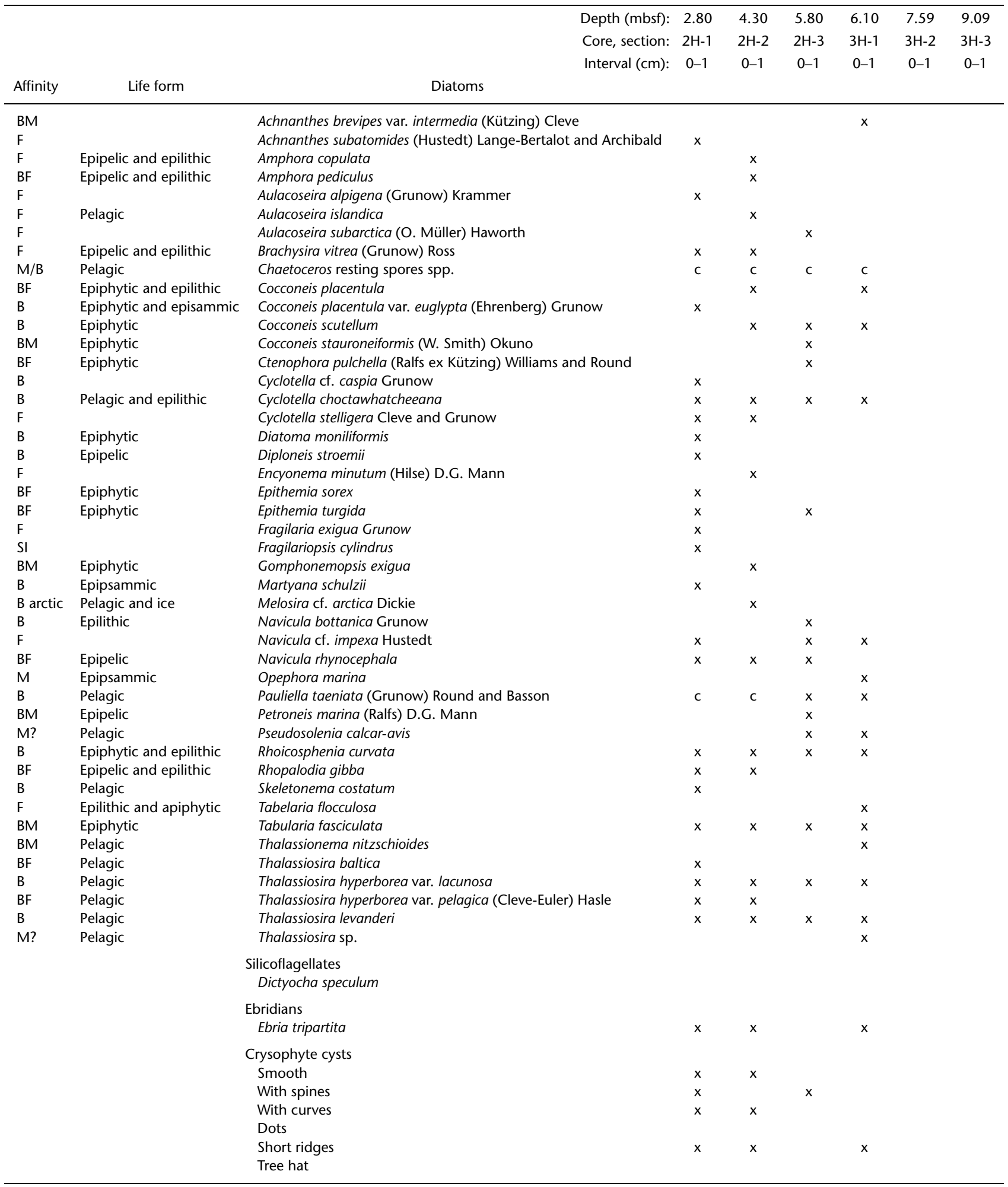

$\mathrm{F}=$ freshwater, $\mathrm{BF}=$ brackish-freshwater, $\mathrm{B}=$ brackish, $\mathrm{BM}=$ brackish-marine, $\mathrm{M}=$ marine, $\mathrm{SI}=$ sea ice indicator. $\mathrm{x}=$ present, $\mathrm{c}=$ common. ? = uncertain. 
Table T4. Species list of diatoms, Site M0061. (Continued on next page.)

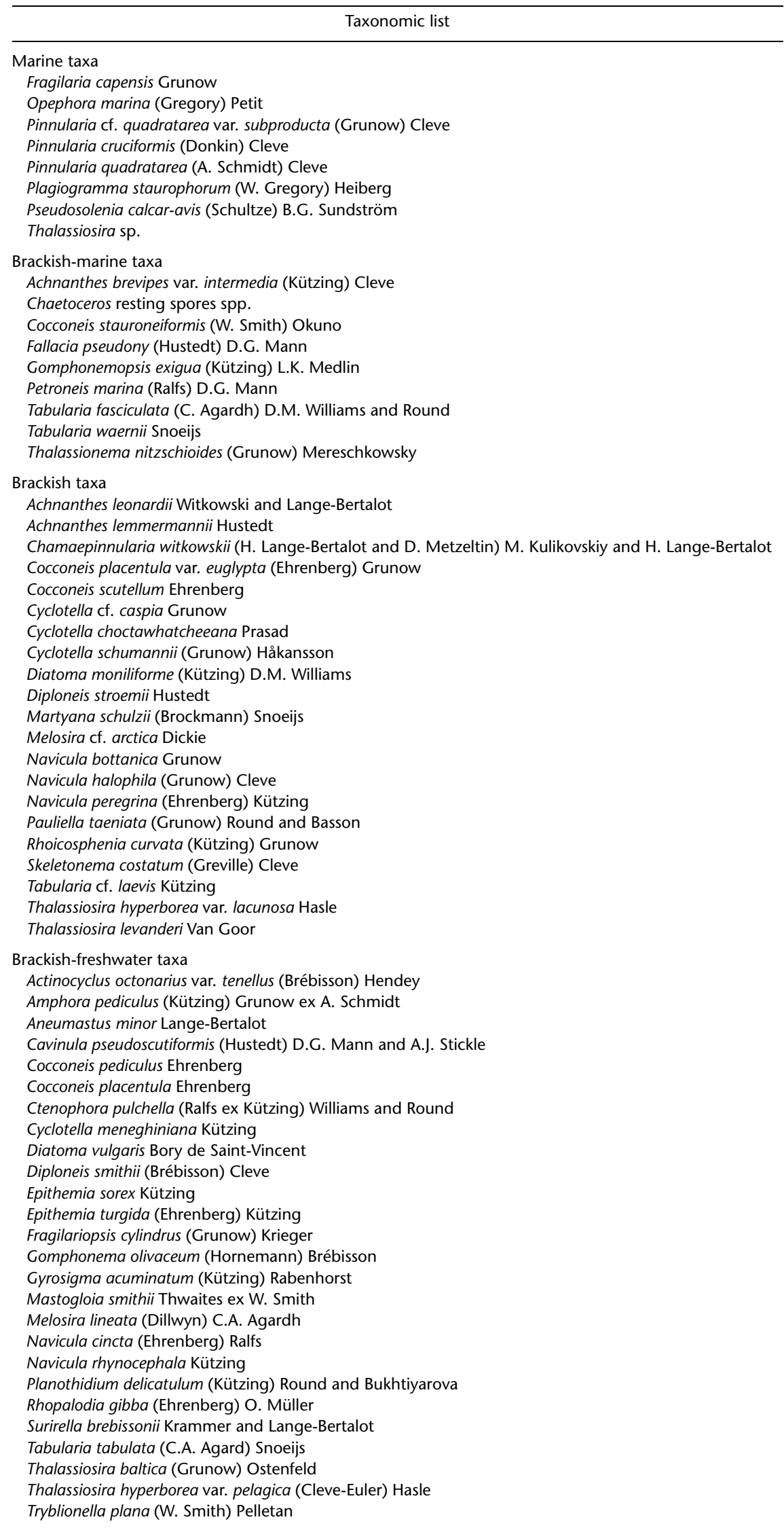


Table T4 (continued).

Taxonomic list

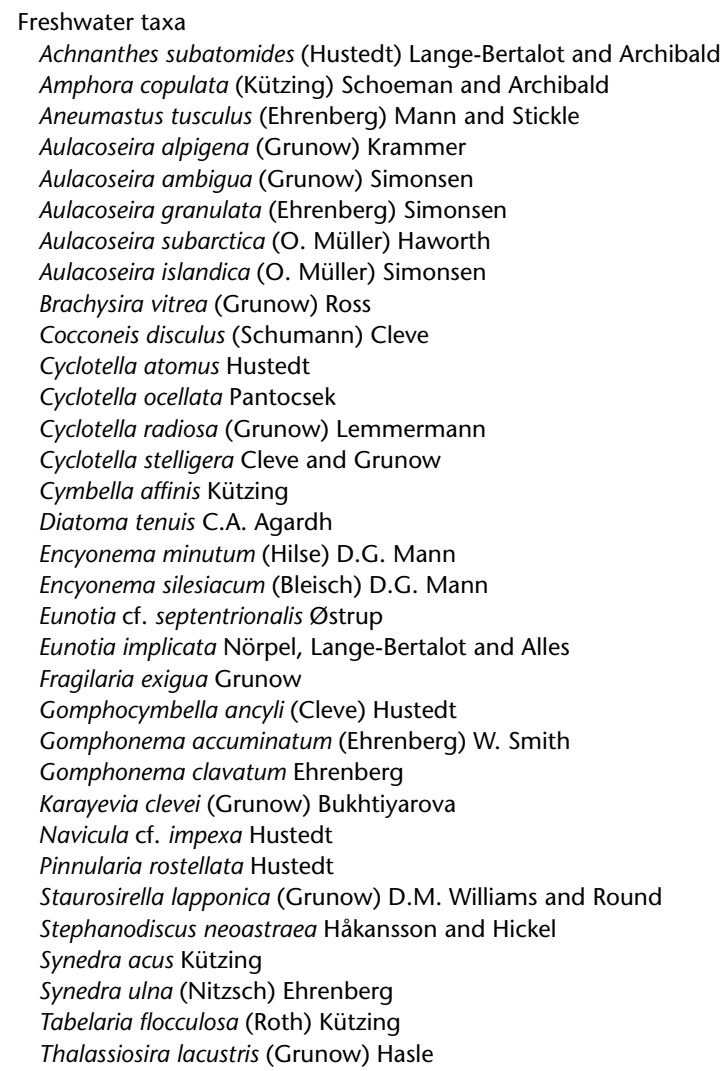

Salinity affinities follows Snoeijs et al. (1993-1998). Diatom authorities according to AlgaeBase (www.algaebase.org). 
Table T5. Foraminifers, Site M0061.

\begin{tabular}{|c|c|c|c|c|c|}
\hline \multirow{2}{*}{$\begin{array}{l}\text { Hole, core, section, } \\
\text { interval }(\mathrm{cm})\end{array}$} & \multicolumn{2}{|c|}{ Depth (mbsf) } & \multirow{2}{*}{ 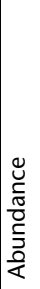 } & \multirow[t]{2}{*}{ 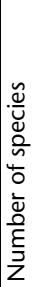 } & \multirow[t]{2}{*}{ 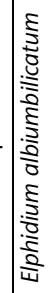 } \\
\hline & Top & Bottom & & & \\
\hline \multicolumn{6}{|l|}{$347-$} \\
\hline M0061B-1H-1, 77-79 & 0.00 & 0.02 & B & & \\
\hline M0061B-1H-1, 17-19 & 0.17 & 0.19 & B & & \\
\hline M0061A-1H-1, 40-42 & 0.40 & 0.42 & B & & \\
\hline M0061A-1H-1, 131-133 & 1.31 & 1.33 & B & & \\
\hline M0061A-1H-CC & 1.38 & 1.53 & B & & \\
\hline M0061C-1H-2, 4-6 & 1.54 & 1.56 & B & & \\
\hline M0061B-1H-2, 17-19 & 1.67 & 1.69 & V & 1 & $x$ \\
\hline M0061B-1H-CC & 2.82 & 2.83 & $\mathrm{R}$ & 1 & $x$ \\
\hline M0061B-2H-1, 15-17 & 2.95 & 2.97 & B & & \\
\hline $\mathrm{M} 0061 \mathrm{~A}-2 \mathrm{H}-2,18-20$ & 3.18 & 3.20 & $\mathrm{~V}$ & 1 & $\mathrm{x}$ \\
\hline M0061C-1H-CC & 3.37 & 3.41 & C & 1 & $\mathrm{x}$ \\
\hline M0061B-2H-2, 15-17 & 4.45 & 4.47 & $\mathrm{R}$ & 1 & $\mathrm{x}$ \\
\hline M0061A-2H-CC & 4.91 & 4.94 & B & & \\
\hline M0061C-2H-2, 13-15 & 4.93 & 4.95 & $\mathrm{~F}$ & 1 & $x$ \\
\hline M0061A-3H-1, 30-32 & 5.10 & 5.12 & $\mathrm{~V}$ & 1 & $\mathrm{x}$ \\
\hline M0061B-2H-CC & 6.21 & 6.23 & V & 1 & $x$ \\
\hline M0061C-2H-CC & 6.70 & 6.72 & B & & \\
\hline M0061C-3H-1, 15-17 & 6.75 & 6.77 & B & & \\
\hline M0061B-3H-2, 13-15 & 7.72 & 7.74 & B & & \\
\hline M0061A-3H-CC & 8.05 & 8.08 & B & & \\
\hline M0061B-3H-CC & 9.53 & 9.54 & B & & \\
\hline M0061A-4H-2, 15-17 & 9.75 & 9.77 & B & & \\
\hline M0061C-3H-CC & 10.02 & 10.04 & B & & \\
\hline M0061C-4H-1, 15-17 & 10.05 & 10.07 & B & & \\
\hline M0061A-4H-CC & 11.25 & 11.28 & B & & \\
\hline M0061B-4H-CC & 12.40 & 12.55 & B & & \\
\hline M0061A-6H-2, 15-17 & 12.85 & 12.87 & B & & \\
\hline M0061C-4H-CC & 13.02 & 13.04 & B & & \\
\hline M0061A-6H-CC & 13.26 & 13.33 & B & & \\
\hline M0061B-5H-2, 15-17 & 14.35 & 14.37 & B & & \\
\hline M0061C-5H-2, 15-17 & 14.85 & 14.87 & B & & \\
\hline M0061B-5H-CC & 15.84 & 15.87 & B & & \\
\hline M0061A-7H-2, 12-14 & 16.12 & 16.14 & B & & \\
\hline M0061B-6H-1, 18-20 & 16.18 & 16.20 & B & & \\
\hline M0061C-5H-CC & 16.52 & 16.57 & B & & \\
\hline M0061A-7H-CC & 17.66 & 17.68 & B & & \\
\hline M0061A-8H-2, 15-17 & 19.25 & 19.27 & $B$ & & \\
\hline M0061B-6H-CC & 19.29 & 19.30 & B & & \\
\hline M0061B-7H-1, 24-26 & 19.54 & 19.56 & B & & \\
\hline M0061C-6H-CC & 19.65 & 19.72 & B & & \\
\hline M0061A-8H-CC & 20.74 & 20.77 & B & & \\
\hline M0061A-9H-2, 15-17 & 22.45 & 22.47 & B & & \\
\hline M0061B-7H-CC & 22.48 & 22.51 & B & & \\
\hline M0061C-7H-CC & 22.95 & 22.97 & B & & \\
\hline M0061A-9H-3 & & 24.03 & B & & \\
\hline M0061B-8H-1, 18-20 & 24.25 & 24.27 & $B$ & & \\
\hline M0061B-8H-CC & 25.65 & 25.69 & B & & \\
\hline M0061A-10H-2, 15-17 & 25.75 & 25.77 & B & & \\
\hline M0061B-9H-2, 15-17 & 27.55 & 27.57 & B & & \\
\hline M0061B-9H-CC & 28.68 & 28.73 & B & & \\
\hline
\end{tabular}

Abundance: $\mathrm{C}=$ common, $\mathrm{R}=$ rare, $\mathrm{B}=$ barren, $\mathrm{V}=$ very high. 
Table T6. Distribution and abundance of ostracods, Site M0061.

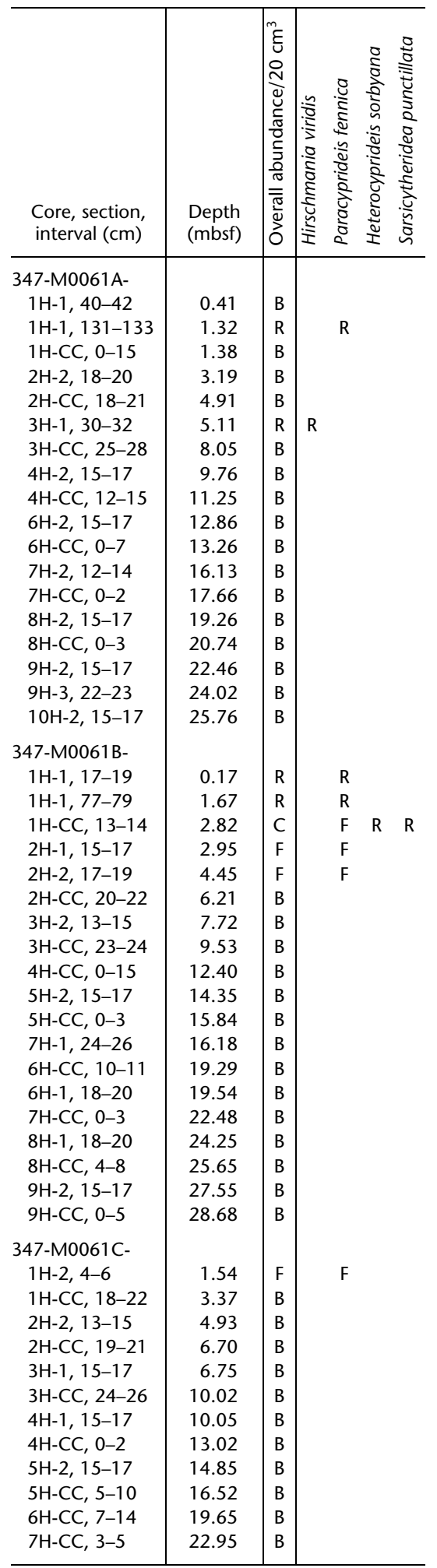

Abundance: $\mathrm{C}=$ common, $\mathrm{F}=$ few $\mathrm{R}=$ rare, $\mathrm{B}=$ barren. 
Table T7. Calculated salinity and elemental ratios of interstitial waters, Site M0061.

\begin{tabular}{|c|c|c|c|c|c|c|c|c|c|c|}
\hline $\begin{array}{l}\text { Core, section, } \\
\text { interval }(\mathrm{cm})\end{array}$ & Type & $\begin{array}{l}\text { Depth } \\
\text { (mbsf) }\end{array}$ & $\begin{array}{l}\mathrm{Cl}^{-} \text {based } \\
\text { salinity }\end{array}$ & $\begin{array}{l}\text { Anion-based } \\
\text { salinity }\end{array}$ & $\begin{array}{c}\mathrm{Na} / \mathrm{Cl} \\
(\mathrm{mM} / \mathrm{mM})\end{array}$ & $\begin{array}{c}\mathrm{Ca} / \mathrm{Cl} \\
(\mathrm{mM} / \mathrm{mM})\end{array}$ & $\begin{array}{c}\mathrm{Mg} / \mathrm{Cl} \\
(\mathrm{mM} / \mathrm{mM})\end{array}$ & $\begin{array}{c}\mathrm{K} / \mathrm{Cl} \\
(\mathrm{mM} / \mathrm{mM})\end{array}$ & $\begin{array}{c}\mathrm{Br} / \mathrm{Cl} \\
(\mu \mathrm{M} / \mathrm{mM})\end{array}$ & $\begin{array}{c}\mathrm{B} / \mathrm{Cl} \\
(\mu \mathrm{M} / \mathrm{mM})\end{array}$ \\
\hline \multicolumn{11}{|l|}{ 347-M0061A- } \\
\hline $1 \mathrm{H}-1,123-128$ & $\mathrm{Rh}$ & 1.23 & 6.11 & 7.34 & 0.82 & 0.02 & 0.09 & 0.02 & 1.57 & 1.01 \\
\hline $2 \mathrm{H}-1,135-140$ & $\mathrm{Rh}$ & 2.85 & 6.79 & 9.64 & 0.82 & 0.03 & 0.10 & 0.02 & 1.65 & 1.21 \\
\hline $2 \mathrm{H}-2,135-140$ & $\mathrm{Rh}$ & 4.35 & 7.18 & 11.53 & 0.84 & 0.03 & 0.10 & 0.02 & 1.67 & 1.21 \\
\hline $3 \mathrm{H}-1,135-140$ & $\mathrm{Rh}$ & 6.15 & 7.70 & 13.85 & 0.82 & 0.04 & 0.10 & 0.02 & 1.62 & 0.94 \\
\hline $3 \mathrm{H}-2,135-140$ & $\mathrm{Rh}$ & 7.65 & 8.00 & 15.65 & 0.80 & 0.04 & 0.10 & 0.02 & 1.64 & 0.70 \\
\hline $4 \mathrm{H}-1,135-140$ & $\mathrm{Rh}$ & 9.45 & 8.09 & 17.54 & 0.78 & 0.05 & 0.09 & 0.02 & 1.63 & 0.52 \\
\hline $4 \mathrm{H}-2,64-69$ & $\mathrm{Rh}$ & 10.24 & 8.20 & 18.44 & 0.77 & 0.06 & 0.09 & 0.01 & 1.62 & 0.42 \\
\hline $6 \mathrm{H}-1,135-140$ & $\mathrm{Rh}$ & 12.55 & 8.24 & 20.79 & 0.73 & 0.07 & 0.08 & 0.01 & 1.61 & 0.21 \\
\hline 7H-1, 135-140 & $\mathrm{Rh}$ & 15.85 & 7.98 & 23.83 & 0.67 & 0.10 & 0.08 & 0.01 & 1.61 & 0.06 \\
\hline 7H- $2,75-80$ & $\mathrm{Rh}$ & 16.75 & 7.94 & 24.69 & 0.66 & 0.10 & 0.08 & 0.01 & 1.60 & 0.03 \\
\hline $8 \mathrm{H}-1,135-140$ & $\mathrm{Rh}$ & 18.95 & 7.96 & 26.91 & 0.71 & 0.12 & 0.09 & 0.01 & 1.61 & 0.00 \\
\hline $8 \mathrm{H}-2,75-80$ & $\mathrm{Rh}$ & 19.85 & 8.02 & 27.87 & 0.63 & 0.11 & 0.08 & 0.01 & 1.61 & 0.00 \\
\hline $9 \mathrm{H}-1,135-140$ & $\mathrm{Rh}$ & 22.15 & 8.28 & 30.43 & 0.63 & 0.13 & 0.10 & 0.01 & 1.59 & 0.00 \\
\hline $10 \mathrm{H}-1,135-140$ & $\mathrm{Rh}$ & 25.45 & 8.32 & 33.77 & 0.58 & 0.13 & 0.09 & 0.01 & 1.53 & 0.00 \\
\hline \multicolumn{11}{|l|}{ 347-M0061B- } \\
\hline $1 \mathrm{H}-1,135-140$ & $\mathrm{Rh}$ & 1.35 & 6.12 & 7.47 & 0.83 & 0.02 & 0.10 & 0.02 & 1.60 & 0.99 \\
\hline $1 \mathrm{H}-2,104-109$ & $\mathrm{Rh}$ & 2.54 & 6.52 & 9.06 & 0.92 & 0.03 & 0.12 & 0.02 & 1.63 & 1.31 \\
\hline $2 \mathrm{H}-1,135-140$ & $\mathrm{Rh}$ & 4.15 & 7.12 & 11.27 & 0.86 & 0.03 & 0.11 & 0.02 & 1.64 & 1.23 \\
\hline $2 \mathrm{H}-2,135-140$ & $\mathrm{Rh}$ & 5.65 & 7.52 & 13.17 & 0.82 & 0.04 & 0.10 & 0.02 & 1.66 & 1.03 \\
\hline $3 \mathrm{H}-1,134-139$ & $\mathrm{Rh}$ & 7.44 & 7.87 & 15.31 & 0.83 & 0.04 & 0.10 & 0.02 & 1.63 & 0.76 \\
\hline $3 \mathrm{H}-2,135-140$ & $\mathrm{Rh}$ & 8.94 & 8.09 & 17.03 & 0.80 & 0.05 & 0.10 & 0.02 & 1.62 & 0.58 \\
\hline $4 \mathrm{H}-1,135-140$ & $\mathrm{Rh}$ & 10.75 & 8.17 & 18.92 & 0.73 & 0.07 & 0.08 & 0.01 & 1.61 & 0.23 \\
\hline $4 \mathrm{H}-2,135-140$ & $\mathrm{Rh}$ & 12.25 & 8.16 & 20.41 & 0.77 & 0.06 & 0.09 & 0.01 & 1.61 & 0.36 \\
\hline $5 \mathrm{H}-1,135-140$ & $\mathrm{Rh}$ & 14.05 & 8.06 & 22.11 & 0.71 & 0.08 & 0.08 & 0.01 & 1.60 & 0.15 \\
\hline $5 \mathrm{H}-2,135-140$ & $\mathrm{Rh}$ & 15.55 & 8.05 & 23.60 & 0.69 & 0.09 & 0.08 & 0.01 & 1.60 & 0.08 \\
\hline $6 \mathrm{H}-1,135-140$ & $\mathrm{Rh}$ & 17.35 & 8.00 & 25.35 & 0.66 & 0.10 & 0.08 & 0.01 & 1.60 & 0.04 \\
\hline $6 \mathrm{H}-2,135-140$ & $\mathrm{Rh}$ & 18.85 & 8.09 & 26.94 & 0.65 & 0.11 & 0.08 & 0.01 & 1.60 & 0.02 \\
\hline 7H-1, 135-140 & $\mathrm{Rh}$ & 20.65 & 8.25 & 28.90 & 0.62 & 0.12 & 0.09 & 0.01 & 1.59 & 0.00 \\
\hline 7H-2, 135-140 & $\mathrm{Rh}$ & 22.15 & 8.44 & 30.59 & 0.60 & 0.13 & 0.09 & 0.01 & 1.58 & 0.00 \\
\hline $8 \mathrm{H}-1,135-140$ & $\mathrm{Rh}$ & 23.95 & 8.62 & 32.57 & 0.57 & 0.15 & 0.10 & 0.01 & 1.57 & 0.00 \\
\hline $9 \mathrm{H}-1,135-140$ & $\mathrm{Rh}$ & 27.25 & 9.22 & 36.47 & 0.52 & 0.16 & 0.10 & 0.01 & 1.55 & 0.00 \\
\hline \multicolumn{11}{|l|}{ 347-M0061C- } \\
\hline $1 \mathrm{H}-1,135-140$ & $\mathrm{Rh}$ & 1.35 & 6.22 & 7.57 & 0.80 & 0.02 & 0.09 & 0.02 & 1.61 & 0.99 \\
\hline $1 \mathrm{H}-2,135-140$ & $\mathrm{Rh}$ & 2.85 & 6.58 & 9.43 & 0.82 & 0.03 & 0.10 & 0.02 & 1.64 & 1.22 \\
\hline $2 \mathrm{H}-1,135-140$ & $\mathrm{Rh}$ & 4.65 & 7.42 & 12.07 & 0.99 & 0.04 & 0.13 & 0.03 & 1.64 & 1.44 \\
\hline $2 \mathrm{H}-2,135-140$ & $\mathrm{Rh}$ & 6.15 & 7.51 & 13.66 & 0.92 & 0.04 & 0.12 & 0.02 & 1.64 & 1.16 \\
\hline $3 \mathrm{H}-1,135-140$ & $\mathrm{Rh}$ & 9.45 & 7.59 & 17.04 & 0.91 & 0.05 & 0.11 & 0.02 & 1.62 & 1.00 \\
\hline $4 \mathrm{H}-1,135-140$ & $\mathrm{Rh}$ & 11.25 & 7.85 & 19.10 & 0.92 & 0.10 & 0.12 & 0.02 & 1.59 & 0.50 \\
\hline $4 \mathrm{H}-2,125-130$ & $\mathrm{Rh}$ & 12.65 & 7.81 & 20.46 & 0.87 & 0.13 & 0.12 & 0.02 & 1.58 & 0.30 \\
\hline $5 \mathrm{H}-1,135-140$ & $\mathrm{Rh}$ & 14.55 & 7.71 & 22.26 & 0.77 & 0.15 & 0.12 & 0.01 & 1.58 & 0.16 \\
\hline $5 \mathrm{H}-2,135-140$ & $\mathrm{Rh}$ & 16.05 & 7.78 & 23.83 & 0.72 & 0.16 & 0.12 & 0.01 & 1.59 & 0.11 \\
\hline $6 \mathrm{H}-1,135-140$ & $\mathrm{Rh}$ & 17.85 & 7.76 & 25.61 & 0.71 & 0.20 & 0.14 & 0.01 & 1.58 & 0.05 \\
\hline $6 \mathrm{H}-2,125-130$ & $\mathrm{Rh}$ & 19.25 & 7.80 & 27.05 & 0.55 & 0.16 & 0.11 & 0.01 & 1.58 & 0.02 \\
\hline 7H-1, 135-140 & $\mathrm{Rh}$ & 21.15 & 7.90 & 29.05 & 0.59 & 0.21 & 0.13 & 0.01 & 1.57 & 0.02 \\
\hline
\end{tabular}

$\mathrm{Rh}=$ Rhizon sample. 
Table T8. Interstitial water geochemistry, Site M0061.

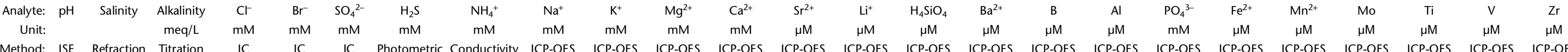
Analyte 347-M0061A- $1 \mathrm{H}-1,123-128$ $1 \mathrm{H}-1,123-128$
$2 \mathrm{H}-1,135-140$
$2 H-2,135$ $2 \mathrm{H}-2,2,135-140$
$3 \mathrm{H}-1,135-140$ $4 \mathrm{H}-1,135-140$
$4 \mathrm{H}-2,64-69$ $4 \mathrm{H}-2,2,64-69$
$6 \mathrm{H}-1,135-140$
$7-1,135-140$ $7 \mathrm{H}-1,1,135-140$
$7 \mathrm{H}-2,75-80$
$8 \mathrm{H}-1,135-140$ $8 \mathrm{H}-1,1,135-140$
$8 \mathrm{H}-2,75-80$ $9 \mathrm{H}-1,135-140$
$10 \mathrm{H}-1,135-140$

347-M0061B-

$1 \mathrm{H}-2,104-109$
$2 \mathrm{H}-1,135-140$

$2 \mathrm{H}-2,133-140$
$3 \mathrm{H}-1,134-139$

$3 \mathrm{H}-\mathrm{-}, 2,135-140$
$4 \mathrm{H}-1,135-140$

$4 \mathrm{H}-2,2,135-140$
$5 \mathrm{H}-1,135-140$

$5 \mathrm{H}-2,135-140$
$6 \mathrm{H}-1,135-140$

$6 \mathrm{H}-1,1,135-140$
$6 \mathrm{H}-2,135-140$
$7 \mathrm{H}-1,135-140$

$7 \mathrm{H}-2,135-140$
$8 \mathrm{H}-1,135-140$

347-M0061C-

$1 \mathrm{H}-1,1,135-140$
$1 \mathrm{H}-2,2,135-140$

$2 \mathrm{H}-1,135-140$
$2 \mathrm{H}-2,135-140$
$3 \mathrm{H}-1,135-140$

$4 \mathrm{H}-1,135-140$

$4 \mathrm{H}-2,125-130$
$5 \mathrm{H}-1,135-140$

$5 \mathrm{H}-2,1,135-140$
$6-1,135-140$
$6 \mathrm{H}-2,125-130$

Reference samples
P2 salt brine mud

R3 seawater from mud pump

R4 grease 1 drill pipe
R5 grease 2 pipes

R6 grease 3 cipes
R7 garrel
R7 grease 4 "moly" pisto . R8 grease 5 pipe the
R9 tap water GC Ri1 $\mathrm{H}_{2}$ Od ELCA
$\mathrm{R} 11$ mud 2 (CS550) R12 mud 3 (guar gum)
R13 drill water
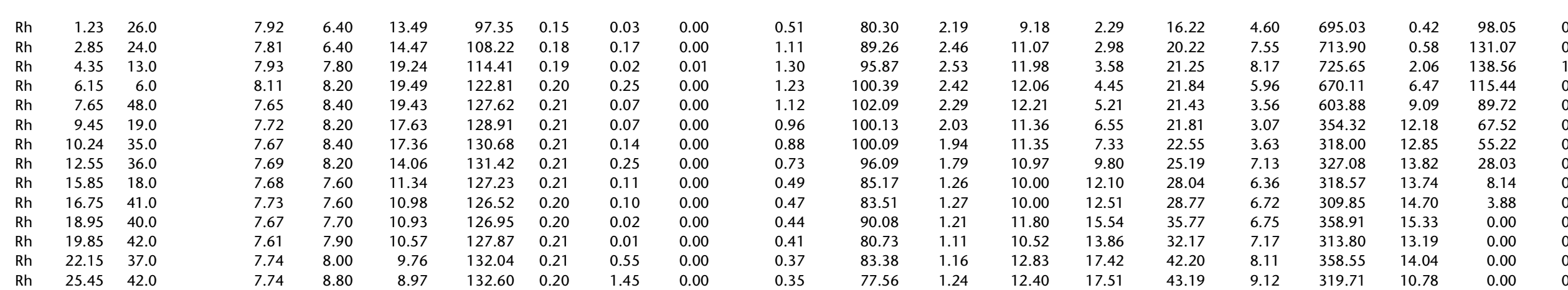

\begin{tabular}{|c|c|c|c|c|c|c|}
\hline 0.38 & 94.62 & 253.01 & 0.04 & 0.23 & & 0.04 \\
\hline 0.54 & 50.84 & 164.66 & 0.04 & 0.10 & 0.11 & 0.02 \\
\hline 0.28 & $\begin{array}{r}6.70 \\
23.64\end{array}$ & $\begin{array}{l}47.11 \\
51.95\end{array}$ & $\begin{array}{l}0.03 \\
0.06\end{array}$ & $\begin{array}{l}0.05 \\
0.04\end{array}$ & $\begin{array}{l}0.10 \\
0.10\end{array}$ & $\begin{array}{l}0.01 \\
0.02\end{array}$ \\
\hline 0.10 & 317.66 & 55.90 & 0.04 & 0.00 & 0.02 & 0.01 \\
\hline 0.04 & & 63.27 & 0.04 & 0.01 & 0.06 & 0.01 \\
\hline 0.03 & $\begin{array}{l}328.95 \\
328\end{array}$ & $\begin{array}{l}71.66 \\
17\end{array}$ & 0.09 & 0.00 & 0.04 & 0. \\
\hline 0.01 & $\begin{array}{l}362.61 \\
264.30\end{array}$ & $\begin{array}{l}1100.63 \\
127.51\end{array}$ & $\begin{array}{l}0.11 \\
0.07\end{array}$ & $\begin{array}{l}0.00 \\
0.01\end{array}$ & $\begin{array}{l}0.06 \\
0.08\end{array}$ & $\begin{array}{l}0 . \\
0 .\end{array}$ \\
\hline 0.00 & $\begin{array}{l}264.30 \\
209.15\end{array}$ & $\begin{array}{l}121.31 \\
114.78\end{array}$ & $\begin{array}{l}0.07 \\
0.14\end{array}$ & $\begin{array}{l}0.01 \\
0.00\end{array}$ & $\begin{array}{l}0.08 \\
0.08\end{array}$ & 0. \\
\hline 0.01 & 253.56 & 111.62 & 0.08 & 0.00 & 0.06 & 00 \\
\hline 0.00 & & 88.88 & & & 0.06 & 00 \\
\hline 0.0 & 116 & 77.94 & 0.04 & 0.00 & 0.07 & 02 \\
\hline
\end{tabular}
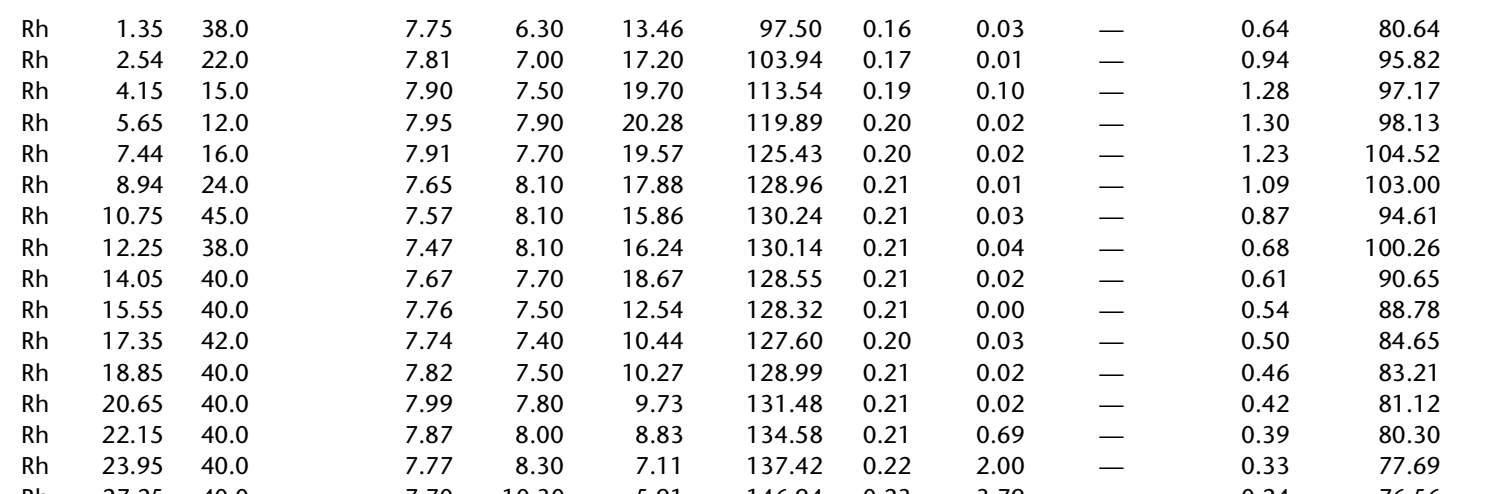

\begin{tabular}{|c|c|}
\hline 9.45 & 2.34 \\
\hline & 3.26 \\
\hline 12.2 & $\begin{array}{l}3.69 \\
4.25\end{array}$ \\
\hline 12.95 & 5.47 \\
\hline & \\
\hline 10.93 & 9.40 \\
\hline 11.65 & 8.27 \\
\hline & \\
\hline 10. & 1280 \\
\hline 10.72 & 13.75 \\
\hline 11.40 & $\begin{array}{l}15.45 \\
17\end{array}$ \\
\hline 1.25 & 17.27 \\
\hline
\end{tabular}

6.47
2.35
2.10
2.50
2.88
2.76
2.40
2.40
2.91
2.72
2.24
3.19
3.19
3.15
3.93
4.94
5.92
5.88
2.07

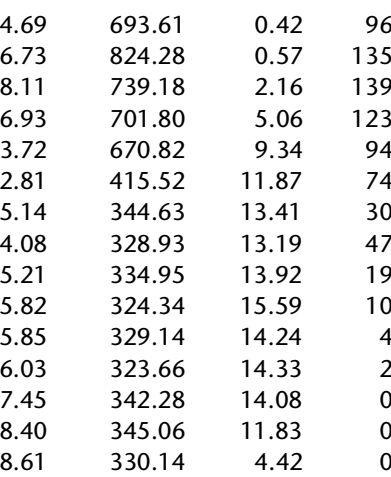
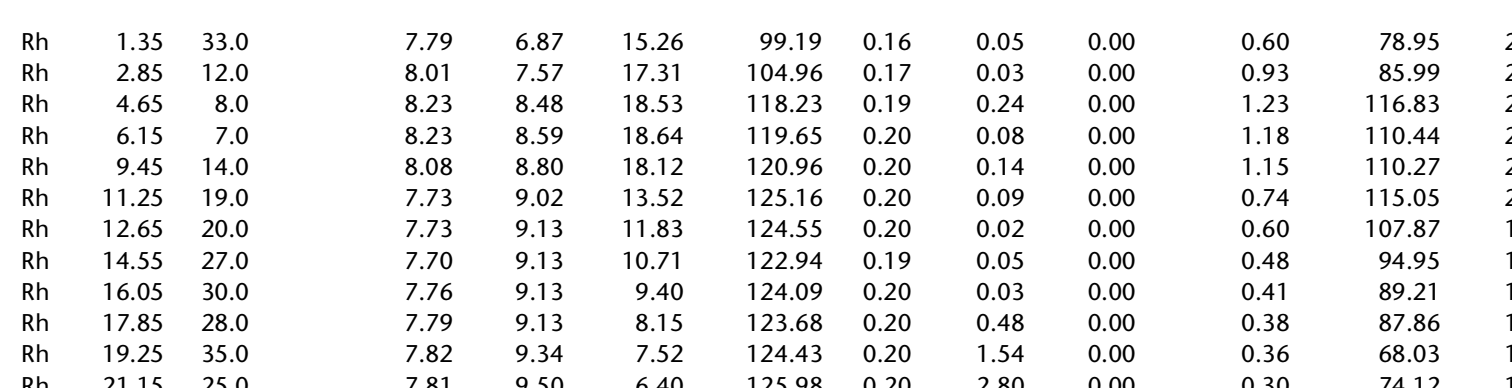

$\begin{array}{rrr}9.15 & 2.28 & 16.1 \\ 10.69 & 2.89 & 19.62 \\ 15.37 & 4.74 & 27.52 \\ 13.89 & 5.16 & 25.5 \\ 13.29 & 5.51 & 24.9 \\ 15.36 & 12.69 & 34.87 \\ 15.48 & 16.12 & 39.43 \\ 14.84 & 18.43 & 42.70 \\ 15.04 & 20.08 & 46.5 \\ 16.95 & 24.45 & 55.23 \\ 13.26 & 20.39 & 45.89 \\ 11.45 & 26.37 & 55.64\end{array}$

\begin{tabular}{|c|c|c|c|}
\hline & & & \\
\hline 8.06 & $\begin{array}{l}700.37 \\
71906\end{array}$ & $\begin{array}{l}0.39 \\
0.54\end{array}$ & $\begin{array}{r}98.60 \\
\end{array}$ \\
\hline 8.62 & 875.56 & $\begin{array}{l}0.54 \\
3.47\end{array}$ & $\begin{array}{l}128.02 \\
170.20\end{array}$ \\
\hline & $\begin{array}{l}789.75 \\
7\end{array}$ & 6.66 & 138.84 \\
\hline $\begin{array}{l}5.54 \\
515\end{array}$ & $\begin{array}{r}798.29 \\
4365\end{array}$ & $\begin{array}{r}8.43 \\
1889\end{array}$ & 121.27 \\
\hline $\begin{array}{l}.515 \\
5.73\end{array}$ & $\begin{array}{l}436.18 \\
453.27\end{array}$ & $\begin{array}{l}88.29 \\
18.61\end{array}$ & $\begin{array}{l}62.44 \\
37.09\end{array}$ \\
\hline $\begin{array}{l}6.02 \\
6.32\end{array}$ & $\begin{array}{l}421.93 \\
41800\end{array}$ & $\begin{array}{l}17.57 \\
17.97\end{array}$ & $\begin{array}{l}19.89 \\
13.78\end{array}$ \\
\hline $\begin{array}{l}.0 .38 \\
6.59\end{array}$ & $\begin{array}{l}418.02 \\
504.54\end{array}$ & 15.44 & $\begin{array}{l}1.18 \\
5.73\end{array}$ \\
\hline 7.00 & 343.96 & 8.37 & 2.87 \\
\hline
\end{tabular}

\begin{tabular}{|c|c|c|c|}
\hline 739 & & & \\
\hline & 125.11 & 250.2 & 0.10 \\
\hline & 5.89 & 50.93 & 0.04 \\
\hline & $\begin{array}{r}3.81 \\
310\end{array}$ & & \\
\hline $\begin{array}{l}0.15 \\
0.07\end{array}$ & $\begin{array}{l}199.46 \\
476.68\end{array}$ & $\begin{array}{l}39.14 \\
60.81\end{array}$ & $\begin{array}{l}0.00 \\
0.03\end{array}$ \\
\hline 0.01 & 344.35 & 109.31 & 0.12 \\
\hline 0.03 & 385.17 & 85.06 & 0.10 \\
\hline $\begin{array}{l}0.01 \\
0.01\end{array}$ & $\begin{array}{l}303.16 \\
252.66\end{array}$ & $\begin{array}{l}124.72 \\
123.78\end{array}$ & $\begin{array}{l}0.08 \\
0.09\end{array}$ \\
\hline $\begin{array}{l}0.01 \\
0.01\end{array}$ & $\begin{array}{l}232.06 \\
256.07\end{array}$ & $\begin{array}{l}1233.78 \\
100.73\end{array}$ & $\begin{array}{l}0.09 \\
0.08\end{array}$ \\
\hline 0.01 & 216.31 & 85.93 & 0.06 \\
\hline 0.00 & & & \\
\hline 0.00 & 62.57 & & \\
\hline
\end{tabular}

$\begin{array}{ll}0.16 & 0.03 \\ 0.10 & 0.02 \\ 0.10 & 0.02 \\ 0.06 & 0.01 \\ 0.04 & 0.01 \\ 0.05 & 0.01 \\ 0.05 & 0.01 \\ 0.04 & 0.01 \\ 0.00 & 0.00 \\ 0.08 & 0.00 \\ 0.09 & 0.00 \\ 0.07 & 0.00 \\ 0.10 & 0.04 \\ 0.09 & 0.02 \\ 0.11 & 0.00\end{array}$
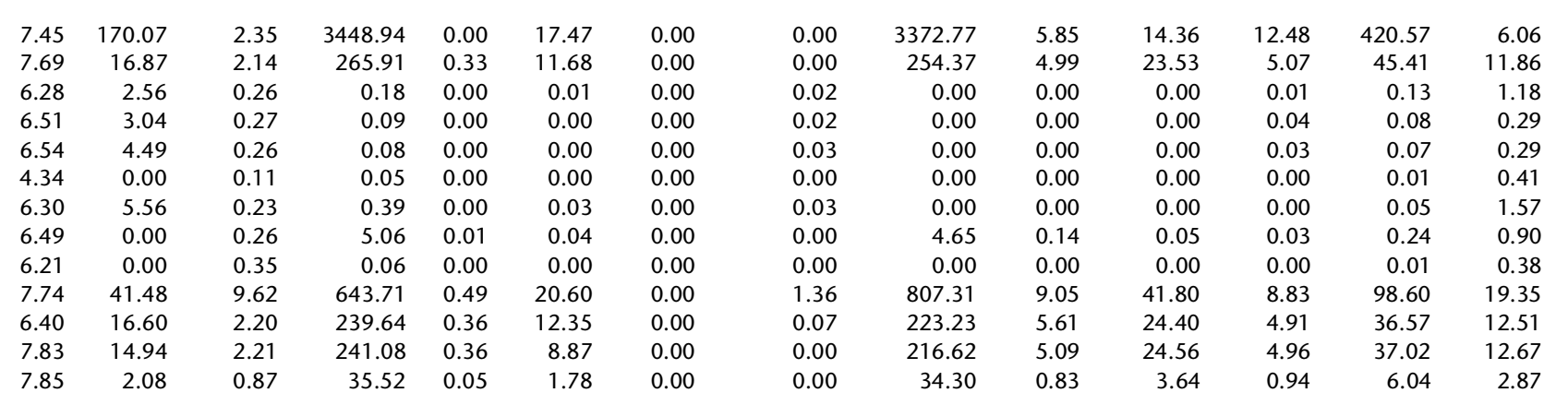

$\begin{array}{rrrrr}35.78 & 8.98 & 137.36 & 0.22 & 0.01 \\ 7.62 & 3.18 & 187.77 & 0.56 & 0.01 \\ 0.57 & 4.69 & 8.69 & 0.00 & 0.01 \\ 0.00 & 4.05 & 6.94 & 0.00 & 0.01 \\ 1.53 & 3.90 & 6.47 & 0.00 & 0.01 \\ 0.00 & 0.43 & 5.09 & 0.00 & 0.01 \\ 0.61 & 3.01 & 6.94 & 0.00 & 0.01 \\ 7.23 & 8.71 & 104.80 & 0.22 & 0.01 \\ 0.53 & 1.30 & 9.99 & 0.37 & 0.01 \\ 23.11 & 1.69 & 343.63 & 1.63 & 0.01 \\ 8.47 & 1.94 & 192.03 & 0.37 & 0.01 \\ 5.70 & 1.88 & 190.27 & 0.00 & 0.01 \\ 34.54 & 8.47 & 35.15 & 0.33 & 0.01\end{array}$

$\begin{array}{lrrll}0.39 & 83.25 & 249.74 & 0.01 & 0.23 \\ 0.55 & 63.23 & 172.23 & 0.02 & 0.13 \\ 0.57 & 7.18 & 47.34 & 0.00 & 0.06 \\ 0.35 & 18.25 & 57.95 & 0.00 & 0.03 \\ 0.23 & 149.02 & 61.96 & 0.00 & 0.04 \\ 0.02 & 313.90 & 12.78 & 0.14 & 0.04 \\ 0.02 & 341.84 & 155.39 & 0.11 & 0.00 \\ 0.02 & 273.61 & 1533.30 & 0.07 & 0.01 \\ 0.02 & 0.00 \\ 0.02 & 157.19 & 124.89 & 0.06 & 0.00 \\ 0.01 & 78.02 & 99.78 & 0.04 & 0.01 \\ 0.01 & 57.09 & 77.37 & 0.03 & 0.01 \\ 0.01 & 71.07 & 87.35 & 0.06 & 0.00 \\ & & & & 0.00 \\ 0.01 & 13.54 & 6.46 & 0.07 & 0.00 \\ 0.01 & 0.00 & 2.87 & 0.06 & 0.00 \\ 0.01 & 0.00 & 2.86 & 0.00 & 0.00 \\ 0.01 & 0.000 & 2.86 & 0.00 & 0.00 \\ 0.01 & 0.00 & 2.86 & 0.00 & 0.01 \\ 0.01 & 0.000 & 2.86 & 0.00 & 0.01 \\ 0.01 & 0.00 & 2.86 & 0.00 & 0.00 \\ 0.01 & 0.00 & 2.89 & 0.03 & 0.00 \\ 0.01 & 0.000 & 2.86 & 0.00 & 0.00 \\ 0.01 & 0.99 & 5.15 & 0.10 & 0.00 \\ 0.01 & 8.90 & 3.02 & 0.05 & 0.00 \\ 0.01 & 0.000 & 2.93 & 0.06 & 0.00 \\ 0.01 & 0.56 & 2.93 & 0.00 \\ 0.01 & 0.00 & 2.87 & 0.00 & 0.01 \\ & & & & \end{array}$

$\mathrm{Rh}=$ Rhizon sample. ISE $=$ ion-specific electrode, IC = ion chromatography, ICP-OES $=$ inductively coupled plasma-optical emission spectroscopy. $-=$ no data reported for samples with insufficient pore water volumes. 
Table T9. Total carbon (TC), total organic carbon (TOC), total inorganic carbon (TIC), and total sulfur (TS) in sediment, Site M0061.

\begin{tabular}{|c|c|c|c|c|c|}
\hline $\begin{array}{l}\text { Core, section, } \\
\text { interval }(\mathrm{cm})\end{array}$ & $\begin{array}{l}\text { Depth } \\
\text { (mbsf) }\end{array}$ & $\begin{array}{c}\mathrm{TC} \\
\text { (wt\%) }\end{array}$ & $\begin{array}{c}\text { TOC } \\
\text { (wt\%) }\end{array}$ & $\begin{array}{c}\mathrm{TIC} \\
(\mathrm{wt} \%)\end{array}$ & $\begin{array}{c}\text { TS } \\
\text { (wt\%) }\end{array}$ \\
\hline \multicolumn{6}{|l|}{ 347-M0061A- } \\
\hline $1 \mathrm{H}-1,74-75$ & 0.74 & 1.43 & 1.34 & 0.09 & 0.68 \\
\hline $2 \mathrm{H}-1,64-65$ & 2.14 & 1.83 & 1.73 & 0.09 & 1.32 \\
\hline $3 \mathrm{H}-1,27-28$ & 5.07 & 2.13 & 2.06 & 0.07 & 1.97 \\
\hline $4 \mathrm{H}-1,35-36.5$ & 8.45 & 0.75 & 0.71 & 0.05 & 0.10 \\
\hline $4 \mathrm{H}-3,50-51.5$ & 10.89 & 0.27 & 0.23 & 0.04 & 0.10 \\
\hline $6 \mathrm{H}-1,61.5-63$ & 11.82 & 0.23 & 0.20 & 0.04 & 0.13 \\
\hline $7 \mathrm{H}-1,70-71$ & 15.20 & 0.14 & 0.09 & 0.05 & 0.13 \\
\hline $7 \mathrm{H}-2,57-58$ & 16.57 & 0.18 & 0.12 & 0.06 & 0.13 \\
\hline $8 \mathrm{H}-1,55-56.5$ & 18.15 & 0.17 & 0.11 & 0.06 & 0.16 \\
\hline $9 \mathrm{H}-1,104-105$ & 21.84 & 0.14 & 0.09 & 0.05 & 0.14 \\
\hline $9 \mathrm{H}-2,144-145$ & 23.74 & 0.10 & 0.09 & 0.01 & 0.11 \\
\hline $10 \mathrm{H}-1,144.5-146$ & 24.49 & 0.16 & 0.10 & 0.06 & 0.13 \\
\hline $10 \mathrm{H}-2,101-102$ & 27.05 & 0.12 & 0.06 & 0.06 & 0.12 \\
\hline \multicolumn{6}{|l|}{ 347-M0061B- } \\
\hline $2 \mathrm{H}-2,31-32$ & 3.81 & 2.29 & 2.18 & 0.11 & 1.21 \\
\hline $2 \mathrm{H}-1,27-34$ & 4.61 & 2.61 & 2.53 & 0.08 & 2.25 \\
\hline $3 \mathrm{H}-1,30-31$ & 6.40 & 1.58 & 1.46 & 0.12 & 0.90 \\
\hline $3 \mathrm{H}-1,83-84$ & 8.42 & 0.90 & 0.84 & 0.05 & 0.14 \\
\hline $5 \mathrm{H}-1,18-19$ & 12.88 & 0.14 & 0.11 & 0.04 & 0.12 \\
\hline $5 \mathrm{H}-2,70-71$ & 14.90 & 0.15 & 0.11 & 0.04 & 0.14 \\
\hline $6 \mathrm{H}-1,71-72$ & 16.71 & 0.13 & 0.09 & 0.04 & 0.13 \\
\hline $7 \mathrm{H}-1,37-38$ & 19.67 & 0.10 & 0.08 & 0.02 & 0.12 \\
\hline $7 \mathrm{H}-2,37-38$ & 21.17 & 0.12 & 0.10 & 0.01 & 0.12 \\
\hline $8 \mathrm{H}-1,52-53$ & 23.12 & 0.09 & 0.08 & 0.02 & 0.12 \\
\hline $8 \mathrm{H}-2,123-124$ & 25.33 & 0.10 & 0.06 & 0.03 & 0.13 \\
\hline $9 \mathrm{H}-1,34-35$ & 26.24 & 0.10 & 0.06 & 0.04 & 0.13 \\
\hline \multicolumn{6}{|l|}{ 347-M0061C- } \\
\hline $1 \mathrm{H}-1,83-84$ & 0.83 & 1.59 & 1.43 & 0.16 & 0.54 \\
\hline $1 \mathrm{H}-2,41-42$ & 1.91 & 1.52 & 1.36 & 0.16 & 0.70 \\
\hline $2 \mathrm{H}-1,39-40$ & 3.69 & 2.35 & 2.13 & 0.21 & 1.37 \\
\hline $3 \mathrm{H}-1,97-98$ & 7.57 & 1.56 & 1.46 & 0.10 & 0.87 \\
\hline $3 \mathrm{H}-2,97-98$ & 9.07 & 0.59 & 0.53 & 0.07 & 0.09 \\
\hline $3 \mathrm{H}-3,7-8$ & 9.67 & 0.74 & 0.72 & 0.02 & 0.10 \\
\hline $5 \mathrm{H}-1,44.5-46$ & 13.65 & 0.18 & 0.13 & 0.05 & 0.13 \\
\hline $6 \mathrm{H}-1,73-74$ & 17.23 & 0.15 & 0.10 & 0.06 & 0.16 \\
\hline $7 \mathrm{H}-1,70-71$ & 20.50 & 0.17 & 0.11 & 0.06 & 0.12 \\
\hline
\end{tabular}

Table T10. Samples taken for cell counts by acridine orange direct count (AODC), Hole M0061K.

\begin{tabular}{lcc}
\hline $\begin{array}{c}\text { Core, section, } \\
\text { interval }(\mathrm{cm})\end{array}$ & $\begin{array}{c}\text { Top depth } \\
(\mathrm{mbsf})\end{array}$ & $\begin{array}{c}\text { AODC } \\
\left(\log \text { cells } / \mathrm{cm}^{3}\right)\end{array}$ \\
\hline $347-\mathrm{M} 0061 \mathrm{~K}-$ & & \\
$1 \mathrm{~L}-1$ & 0.01 & 9.53 \\
$1 \mathrm{~L}-1,3$ & 0.04 & 9.73 \\
$1 \mathrm{~L}-1,11$ & 0.12 & 9.49 \\
$1 \mathrm{~L}-1,19$ & 0.20 & 9.49 \\
$1 \mathrm{~L}-1,27$ & 0.28 & 9.27 \\
$1 \mathrm{~L}-1,35$ & 0.36 & 9.37 \\
$1 \mathrm{~L}-1,43$ & 0.44 & 9.12 \\
$1 \mathrm{~L}-1,51$ & 0.52 & 9.10 \\
$1 \mathrm{~L}-1,59$ & 0.60 & 9.16 \\
$1 \mathrm{~L}-1,67$ & 0.68 & 9.00 \\
$1 \mathrm{~L}-1,75$ & 0.76 & 8.86 \\
$1 \mathrm{~L}-1,83$ & 0.84 & 8.86 \\
$1 \mathrm{~L}-1,91$ & 0.92 & 8.84 \\
\hline
\end{tabular}

Count data are presented in logarithmic format. 
Table T11. Composite depth scale, Site M0061.

\begin{tabular}{|c|c|c|c|}
\hline \multirow[b]{2}{*}{ Core } & \multirow{2}{*}{$\begin{array}{l}\text { Offset } \\
(\mathrm{m})\end{array}$} & \multicolumn{2}{|c|}{ Top depth } \\
\hline & & (mbsf) & (mcd) \\
\hline \multicolumn{4}{|c|}{ 347-M0061A- } \\
\hline $1 \mathrm{H}$ & -0.13 & 0 & -0.13 \\
\hline $2 \mathrm{H}$ & 0.13 & 1.5 & 1.63 \\
\hline $3 \mathrm{H}$ & 0.20 & 4.8 & 5.00 \\
\hline $4 \mathrm{H}$ & 0.32 & 8.1 & 8.42 \\
\hline $5 \mathrm{H}$ & 0.32 & & 0.32 \\
\hline $6 \mathrm{H}$ & 0.32 & 11.2 & 11.52 \\
\hline $7 \mathrm{H}$ & 0.10 & 14.5 & 14.60 \\
\hline $8 \mathrm{H}$ & 0.01 & 17.6 & 17.61 \\
\hline $9 \mathrm{H}$ & 0.01 & 20.8 & 20.81 \\
\hline $10 \mathrm{H}$ & 0.36 & 24.1 & 24.46 \\
\hline \multicolumn{4}{|c|}{ 347-M0061B- } \\
\hline $1 \mathrm{H}$ & 0.13 & 0 & 0.13 \\
\hline $2 \mathrm{H}$ & 0.06 & 2.8 & 2.86 \\
\hline $3 \mathrm{H}$ & 0.25 & 6.1 & 6.35 \\
\hline $4 \mathrm{H}$ & -0.13 & 9.4 & 9.27 \\
\hline $5 \mathrm{H}$ & -0.13 & 12.7 & 12.57 \\
\hline $6 \mathrm{H}$ & -0.13 & 16 & 15.87 \\
\hline $7 \mathrm{H}$ & -0.13 & 19.3 & 19.17 \\
\hline $8 \mathrm{H}$ & 0.03 & 22.6 & 22.63 \\
\hline $9 \mathrm{H}$ & 0.03 & 25.9 & 25.93 \\
\hline \multicolumn{4}{|c|}{ 347-M0061C- } \\
\hline $1 \mathrm{H}$ & 0.00 & 0 & 0.00 \\
\hline $2 \mathrm{H}$ & 0.00 & 3.3 & 3.30 \\
\hline $3 \mathrm{H}$ & 0.38 & 6.6 & 6.98 \\
\hline $4 \mathrm{H}$ & 0.10 & 9.9 & 10.00 \\
\hline $5 \mathrm{H}$ & -0.19 & 13.2 & 13.01 \\
\hline $6 \mathrm{H}$ & -0.38 & 16.5 & 16.12 \\
\hline $7 \mathrm{H}$ & -0.57 & 19.8 & 19.23 \\
\hline
\end{tabular}

Table T12. Splice tie points, Site M0061.

\begin{tabular}{|c|c|c|c|c|}
\hline $\begin{array}{l}\text { Hole, core, section, } \\
\text { interval }(\mathrm{cm})\end{array}$ & $\begin{array}{l}\text { Depth } \\
\text { (mbsf) }\end{array}$ & $\begin{array}{l}\text { Depth } \\
\text { (mcd) }\end{array}$ & & $\begin{array}{l}\text { Hole, core, section, } \\
\text { interval }(\mathrm{cm})\end{array}$ \\
\hline \multicolumn{4}{|l|}{ 347- } & $347-$ \\
\hline M0061C-1H-2, 147 & 2.85 & 2.98 & Tie to & M0061A-2H-1, 134 \\
\hline M0061A-2H-2, 80 & 3.93 & 3.93 & Tie to & M0061C-2H-1, 63 \\
\hline M0061C-2H-2, 128 & 5.89 & 6.09 & Tie to & M0061A-3H-1, 109 \\
\hline M0061A-3H-2, 111 & 7.36 & 7.61 & Tie to & M0061B-3H-1, 126 \\
\hline M0061B-3H-2, 126 & 8.79 & 9.11 & Tie to & M0061A-4H-1, 68 \\
\hline M0061A-4H-3, 8 & 10.70 & 10.80 & Tie to & M0061C-4H-1, 80 \\
\hline M0061C-4H-2, 114 & 12.32 & 12.64 & Tie to & M0061A-6H-1, 111 \\
\hline M0061A-6H-2, 23 & 13.38 & 13.25 & Tie to & M0061B-5H-1, 68 \\
\hline M0061B-5H-2, 26 & 14.52 & 14.33 & Tie to & M0061C-5H-1, 132 \\
\hline M0061C-5H-2, 106 & 15.47 & 15.57 & Tie to & M0061A-7H-1, 96 \\
\hline M0061A-7H-3, 18 & 17.58 & 17.19 & Tie to & M0061C-6H-1, 107 \\
\hline M0061C-6H-2, 107 & 18.69 & 18.69 & Tie to & M0061A-8H-1, 108 \\
\hline M0061A-8H-3, 40 & 20.99 & 20.41 & Tie to & M0061C-7H-1, 118 \\
\hline M0061C-7H-2, 137 & 22.09 & 22.10 & Tie to & M0061A-9H-1, 128 \\
\hline M0061A-9H-2, 115 & 23.44 & 23.47 & Tie to & M0061B-8H-1, 83 \\
\hline M0061B-8H-2, 96 & 24.73 & 25.09 & Tie to & M0061A-10H-1, 62 \\
\hline M0061A-10H-2, 60 & 26.54 & 26.57 & Tie to & M0061B-9H-1, 64 \\
\hline
\end{tabular}


Table T13. Sound velocity data for lithologic units, Site M0061.

\begin{tabular}{lccccc}
\hline Unit & $\begin{array}{c}\text { Thickness } \\
\text { of unit } \\
(\mathrm{m})\end{array}$ & $\begin{array}{c}\text { Sound } \\
\text { velocity } \\
(\mathrm{m} / \mathrm{s})^{*}\end{array}$ & $\begin{array}{c}\text { TWT } \\
(\mathrm{ms})\end{array}$ & $\begin{array}{c}\text { Depth } \\
(\mathrm{m})\end{array}$ & $\begin{array}{c}\text { Depth } \\
(\mathrm{mbsf})\end{array}$ \\
\hline Water & 86 & 1430 & 0.1203 & 86 & 0 \\
I & 2.3 & 1472 & 0.1234 & 88.3 & 2.3 \\
II & 5.8 & 1472 & 0.1313 & 94.1 & 8.1 \\
III & 6.4 & 1472 & 0.1400 & 100.5 & 14.5 \\
IV & 14.2 & 1461 & 0.1594 & 114.7 & 28.7 \\
\hline
\end{tabular}

* = sound velocities are based on values measured during the OSP. TWT = two-way traveltime. 